\title{
The Role of the Nuclear Factor $\kappa B$ Pathway in the Cellular Response to Low and High Linear Energy Transfer Radiation
}

\author{
Christine E. Hellweg ${ }^{1, *(\mathbb{D})}$, Luis F. Spitta ${ }^{1}$, Kristina Koch ${ }^{1}$, Arif A. Chishti ${ }^{1,2}$, \\ Bernd Henschenmacher ${ }^{1}$, Sebastian Diegeler ${ }^{1}$, Bikash Konda ${ }^{1}$, Sebastian Feles ${ }^{1}$, \\ Claudia Schmitz ${ }^{1}$, Thomas Berger ${ }^{1}$ (i) and Christa Baumstark-Khan ${ }^{1}$ \\ 1 German Aerospace Centre (DLR), Institute of Aerospace Medicine, Radiation Biology, Linder Höhe, \\ D-51147 Köln, Germany; luis.spitta@dlr.de (L.F.S.); tkoch@mediomix.de (K.K.); \\ arif.chishti@kibge.edu.pk (A.A.C.); bernd.henschenmacher@dlr.de (B.H.); sebastian.diegeler@dlr.de (S.D.); \\ bikash.konda@dlr.de (B.K.); sebastian.feles@dlr.de (S.F.); claudia.schmitz@dlr.de (C.S.); \\ thomas.berger@dlr.de (T.B.); christa.baumstark-khan@dlr.de (C.B.-K.) \\ 2 The Karachi Institute of Biotechnology and Genetic Engineering, University of Karachi, \\ Karachi 75270, Sindh, Pakistan \\ * Correspondence: christine.hellweg@dlr.de; Tel.: +49-2203-601-3243
}

Received: 30 June 2018; Accepted: 24 July 2018; Published: 30 July 2018

\begin{abstract}
Astronauts are exposed to considerable doses of space radiation during long-term space missions. As complete shielding of the highly energetic particles is impracticable, the cellular response to space-relevant radiation qualities has to be understood in order to develop countermeasures and to reduce radiation risk uncertainties. The transcription factor Nuclear Factor $\kappa B(N F-\kappa B)$ plays a fundamental role in the immune response and in the pathogenesis of many diseases. We have previously shown that heavy ions with a linear energy transfer (LET) of 100-300 keV/ $\mu \mathrm{m}$ have a nine times higher potential to activate NF- $\mathrm{BB}$ compared to low-LET $X$-rays. Here, chemical inhibitor studies using human embryonic kidney cells (HEK) showed that the DNA damage sensor Ataxia telangiectasia mutated (ATM) and the proteasome were essential for NF- $\kappa B$ activation in response to X-rays and heavy ions. NF- $k B$ 's role in cellular radiation response was determined by stable knock-down of the NF- $\mathrm{B}$ B subunit RelA. Transfection of a RelA short-hairpin RNA plasmid resulted in higher sensitivity towards X-rays, but not towards heavy ions. Reverse Transcriptase real-time quantitative PCR (RT-qPCR) showed that after exposure to X-rays and heavy ions, NF- $\mathrm{B}$ predominantly upregulates genes involved in intercellular communication processes. This process is strictly NF- $\mathrm{BB}$ dependent as the response is completely absent in RelA knock-down cells. NF-kB's role in the cellular radiation response depends on the radiation quality.
\end{abstract}

Keywords: nuclear factor $\mathrm{kB}$; RelA; linear energy transfer; heavy ion; space mission; cytokines; chemokines; cellular radiation response

\section{Introduction}

Exposure to galactic cosmic radiation which consists of protons, $\alpha$-particles and heavier nuclei is a major risk factor for long-term human space missions. On the International Space Station (ISS), the effective dose rate quantified by human phantom experiments amounted to $550-570 \mu S v / d$ inside the station and 690-720 $\mu \mathrm{Sv} / \mathrm{d}$ during extravehicular activities [1,2]. During a mission to Mars, astronauts will accumulate considerable doses of galactic cosmic radiation of about $1 \mathrm{~Sv}[3,4]$. Due to mass limitations for spacecraft and production of secondary particles in shielding material, the radiation exposure cannot simply be avoided by radiation shielding of the spacecraft [5]. The potential space 
radiation risks are cancer and non-cancer effects such as cataract formation [6,7] and degenerative effects in the central nervous and cardiovascular system [8,9]. Furthermore, acute effects may arise after exposure to a solar particle event during a situation of insufficient shielding [10,11].

Although heavy nuclei only make up about $2 \%$ of the fluence in space, they will account for much of the biological consequences due to their higher linear energy transfer (LET) [12]. Traversal of heavy nuclei through cellular structures produces ionization tracks along their path, resulting in the formation of complex DNA damage [13] which elicits the DNA damage response (DDR) leading to several possible outcomes, such as cell cycle arrest, allocating additional time for repair of the damaged DNA, cellular senescence or different types of cell death, if the damage is too severe and cannot be repaired [14] (reviewed in Hellweg et al., IJPT, in press). The transcription factor Nuclear Factor $\kappa B(N F-\kappa B)$ is involved e.g., in regulation of proliferation, immune system development and performance, inflammation and apoptosis [15]. The activation NF- $\mathrm{kB}$ by ionizing radiation [16] was discovered early after its first description [17]. Exposure to accelerated heavy ions (95 MeV/nucleon-MeV/n-Ar, LET $272 \mathrm{keV} / \mu \mathrm{m}$ ) resulted in much stronger activation of NF- $\mathrm{KB}$ in human cells than X-ray exposure [18]. The NF- $\mathrm{kB}$ activation by energetic carbon ions (35 and $75 \mathrm{MeV} / \mathrm{n}$, LET 73 and $33 \mathrm{keV} / \mu \mathrm{m}$, respectively) was comparable to the effect induced by X-rays [19], suggesting a narrow peak in the LET dependence of NF- $\mathrm{KB}$ activation. This was confirmed by studies with a large set of heavy ions, covering a LET range of $\sim 30-10,000 \mathrm{keV} / \mu \mathrm{m}$, which revealed a maximal NF-KB activation by heavy ions in a LET range of $\sim 91-272 \mathrm{keV} / \mu \mathrm{m}$ [20]. This LET range is highly relevant for space radiation exposure of astronauts [21]. Furthermore, during the last fifteen years, in addition to the canonical and alternative pathways of NF-kB activation, a direct pathway for its activation by genotoxic stress was discovered. This sub-pathway involves a nuclear to cytoplasmic shuttle that transports the information from radiation-induced DNA double strand breaks in the cell nucleus to the cytoplasm where NF- $\mathrm{KB}$ is sequestered in its inactive state [22,23]. The released NF- $\mathrm{KB}$ translocates to the nucleus and binds to $\mathrm{KB}$ DNA motifs (NF- $\mathrm{KB}$ response elements, NRE) initiating gene transcription. NRE have been identified in the promoter or enhancer regions of a number of growth factors, antiapoptotic molecules, cytokines and adhesion molecules involved in fibrosis and inflammation $[24,25]$. Our recent work showed that the expression level of several NF-kB-dependent cyto- and chemokines after heavy ion exposure follows a similar LET dependence as NF- $\mathrm{kB}$ activation itself [26].

As NF- $\mathrm{KB}$ is involved in regulation of apoptosis and immune and inflammatory responses, its activation may influence the outcome of a heavy ion exposed cell (cellular survival/death, cell cycle arrest, DNA repair) and therefore might be relevant for late effects which might occur after prolonged low-dose exposure during an interplanetary mission and might be potential pharmacological target for mitigation of the radiation response. The aim of this work was to analyze the role of the NF-KB pathway in the cellular response to exposure to space-relevant high-LET radiation.

In order to enable monitoring of radiation-induced NF- $\mathrm{KB}$ activation, a previously developed reporter cell line, HEK-pNF-kB-d2EGFP/Neo L2 [27], was used. This cell line harbors a plasmid which reports NF- $\kappa \mathrm{B}$-dependent transcriptional activation in response to various stimuli simply by expressing the destabilized variant of enhanced green fluorescent protein (d2EGFP) [28] when activated NF- $\mathrm{KB}$ binds to its synthetic promoter which contains four NRE tandem copies. By measuring the yields of green fluorescence of the reporter protein it is possible to quantify NF- $\mathrm{kB}$-dependent transcriptional activation in response to stimuli.

To assess the role of NF- $\mathrm{KB}$ in the cellular response to heavy ion exposure, besides the use of chemical inhibitors, the expression of the NF- $\mathrm{kB}$ subunit p65/RelA was downregulated by stable transfection of the reporter cell line with a RelA short-hairpin RNA (shRNA RelA). Growth, cell cycle progression, survival and gene expression after ionizing radiation exposure (low- and high-LET) were compared for cells with normal and reduced RelA expression. Due to limited beam time availability, heavy ion experiments were restricted to high-dose rate exposures. 


\section{Results}

The role of the NF- $\mathrm{B}$ p pathway in the cellular response to low and high-LET radiation was studied in human embryonic kidney cells.

\subsection{Kinetics of $N F-\kappa B$ Activation}

The kinetics of NF-kB-dependent expression of the reporter gene d2EGFP was determined after exposure to 10.9 Gy X-rays, 10.9 Gy carbon ions or $10 \mathrm{ng} / \mathrm{mL}$ tumor necrosis factor $\alpha$ (TNF- $\alpha)($ Figure 1$)$. The high dose was chosen as X-rays are a weak activator of NF- $\mathrm{B}$. The activation was strongest in response to TNF- $\alpha$ and reached a maximum after $20 \mathrm{~h}$. After irradiation, the maximum was reached already after $16 \mathrm{~h}$. Two days after carbon ion exposure and after addition of TNF- $\alpha$, NF- $\mathrm{B}$ dependent d2EGFP expression was still detectable in $\sim 30 \%$ and $\sim 50 \%$ of the cells, respectively. Activation by $X$-rays was transient and reached normal levels within one day.

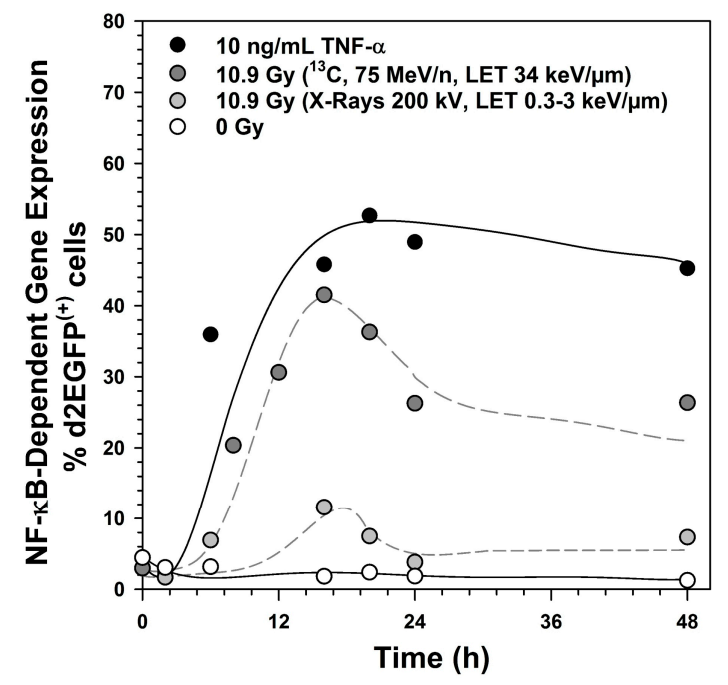

Figure 1. Kinetics of Nuclear Factor $\kappa B$ (NF- $\kappa B$ )-dependent destabilized enhanced green fluorescent protein (d2EGFP) expression after treatment with tumor necrosis factor $\alpha$ (TNF- $\alpha$ ), X-rays and carbon ions, as detected in stably transfected human embryonic kidney cells (HEK) cells from $\mathrm{d} 2 \mathrm{EGFP}$ reporter gene expression controlled by a promoter containing four NF- $\mathrm{kB}$ response elements (NRE) and the minimal promoter of thymidine kinase (TK) (HEK-pNF-kB-d2EGFP/Neo clone L2). HEK-pNF-kB-d2EGFP/Neo L2 cells were irradiated with X-rays (200 kV, linear energy transfer (LET) $\sim 0.3-3 \mathrm{keV} / \mu \mathrm{m})$ or ${ }^{13} \mathrm{C}$-ions $(75 \mathrm{MeV} / \mathrm{n}$, LET $34 \mathrm{keV} / \mu \mathrm{m})$ or incubated with $10 \mathrm{ng} / \mathrm{mL}$ TNF- $\alpha$ as a positive control. At different time points after induction, cells were trypsinated and fixed with $3.7 \%$ formaldehyde. d2EGFP expression was analyzed by flow cytometry.

2.2. Ataxia Telangiectasia Mutated (ATM) and the Proteasome Are Required for NF- $\kappa B$ Activation by X-rays and Heavy Ion Exposure

To determine whether ATM and the proteasome are involved in NF- $\mathrm{B}$ activation by different ionizing radiation qualities, specific inhibitors were used. First, cytotoxicity of the inhibitors and the inhibitory concentration were determined (Figure 2A). $2 \mu \mathrm{mol} / \mathrm{L} \mathrm{MG}-132$ were sufficient to completely suppress TNF- $\alpha$ induced NF- $\kappa$ B activation (Figure 2B). The ATM inhibitor KU-55933 had no effect on TNF- $\alpha$ triggered NF- $\kappa B$ activation, as it is not involved in the classical pathway (Figure $2 \mathrm{C}$ ). Therefore, the concentration was determined from the literature $(10 \mu \mathrm{mol} / \mathrm{L})$. Treatment with $2 \mu \mathrm{mol} / \mathrm{L}$ MG-132 or $10 \mu \mathrm{mol} / \mathrm{L}$ KU-55933 completely abolished the X-ray-induced NF- $\mathrm{KB}$ activation (Figure 2D). Compared to $\mathrm{X}$-rays in the same dose range, exposure with argon ions resulted in a higher NF- $\mathrm{B}$ activation with a saturation at $\sim 8 \mathrm{~Gy}$ (Figure $2 \mathrm{E}$ ). Additionally, this activation was completely suppressed by KU-55933 and by MG-132 (Figure 2E). 

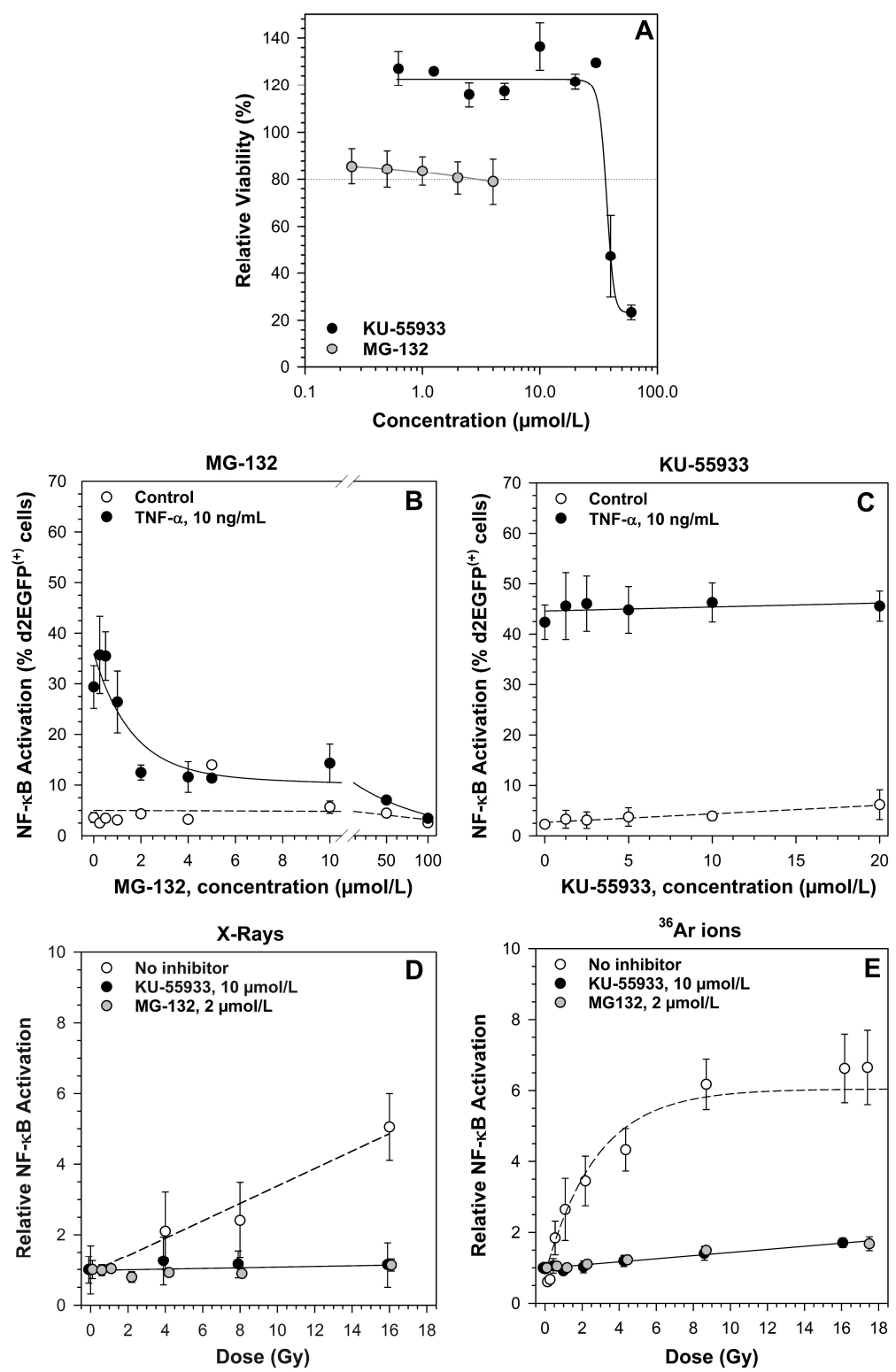

Figure 2. Ataxia telangiectasia mutated (ATM) and the proteasome are required for NF- $\mathrm{kB}$ activation by low and high LET radiation. Means and standard error (SE) of two to three independent experiments with three replicates each are shown. The viability of HEK-pNF-kB-d2EGFP/Neo L2 cells after treatment with increasing concentrations of ATM inhibitor KU-55933 and the proteasome inhibitor MG-132 was determined by means of the 3-(4,5-dimethylthiazole-2-yl-2,5-diphenyltetra- zolium bromide (MTT) test $100 \mathrm{~h}$ after adding the inhibitor. The dotted line indicates $80 \%$ relative viability (A); the effect of MG-132 (B) and KU-55933 (C) on TNF- $\alpha$-induced activation of the NF- $\kappa$ B pathway was determined in HEK-pNF-kB-d2EGFP/Neo L2 cells preincubated with the inhibitor for $1 \mathrm{~h}$ before addition of $10 \mathrm{ng} / \mathrm{mL}$ TNF- $\alpha$. Cells were detached and fixed with $3.7 \%$ formaldehyde after 18 h. NF-kB-dependent d2EGFP-expression was measured by flow cytometry. The suppression of radiation-induced activation of the NF- $\mathrm{kB}$ pathway by KU-55933 and MG-132 was determined in HEK-pNF- $\kappa$ B-d2EGFP/Neo L2 cells after exposure to X-rays (200 kV, LET $\sim 0.3-3 \mathrm{keV} / \mu \mathrm{m}$, (D) and ${ }^{36}$ Ar-ions $(95 \mathrm{MeV} / \mathrm{n}$, LET $270 \mathrm{keV} / \mu \mathrm{m}$, (E) cells were preincubated with the inhibitor for $1 \mathrm{~h}$ and subsequently irradiated. After $18 \mathrm{~h}$, NF-kB-dependent d2EGFP-expression was measured by flow cytometry. The percentage of $\mathrm{d} 2 \mathrm{EGFP}(+)$ cells was normalized to the mock-irradiated control. For ${ }^{36} \mathrm{Ar}$ ions, doses (Gy) were calculated from fluences $\left(\mathrm{P} / \mathrm{cm}^{2}\right)$ according to Equation (1) (Section 4.5.3.). 


\subsection{Effect of RelA Knock-Down on NF-kB-Dependent Gene Expression}

The reporter gene and inhibitor experiments had shown that ATM and the proteasome are involved in ionizing radiation-induced NF- $\mathrm{kB}$ activation. For specific downregulation of the NF- $\mathrm{kB}$ pathway, the key component RelA was knocked down by stable transfection of four different RelA shRNA plasmids carrying a hygromycin resistance gene. The knock-down level in polyclonal hygromycin-resistant cells resulting from transfection with RELA- 1 and -4 plasmids was above $40 \%$ (Figure 3A). Clones from these populations were grown, and three clones reached a knock-down level above $70 \%$. The clone with the highest knock-down was selected for further experiments and designated HEK shRNA RelA (Figure 3B, arrow).
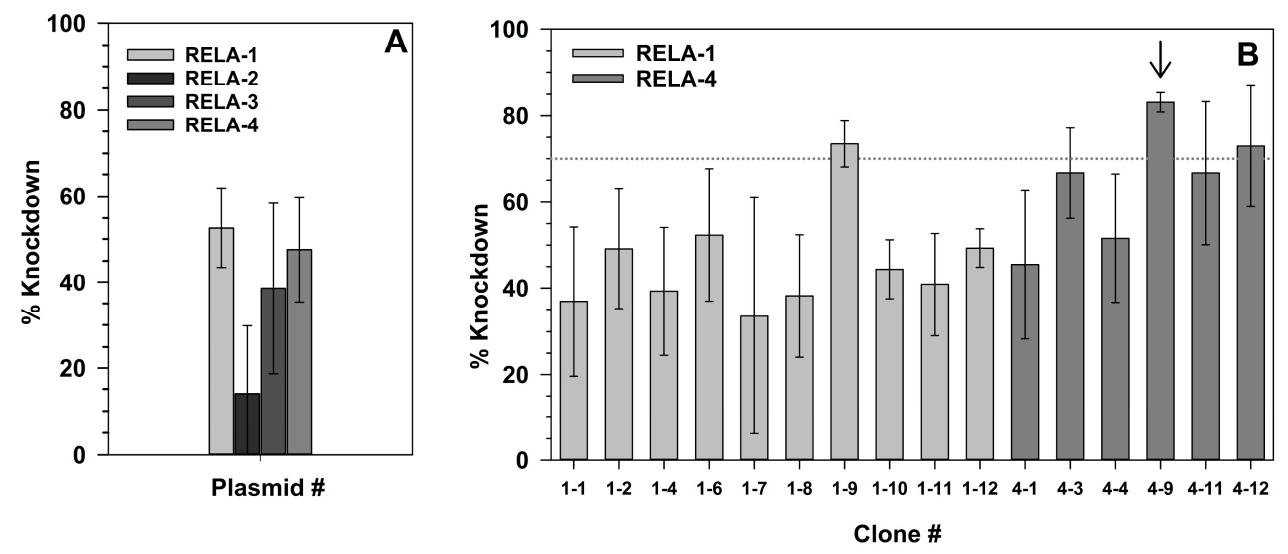

Figure 3. Verification of RelA knock-down on messenger RNA (mRNA) level after transfection of HEK-pNF-кB-d2EGFP/Neo L2 cells with RelA short-hairpin RNA (shRNA) plasmids. Polyclonal hygromycin-resistant cells resulting from transfection with the shRNA plasmids RELA-1 to 4 were grown in petri dishes and total RNA was collected after 3 days (A). Clones were grown from the cell population transfected with the shRNA plasmids RELA-1 and 4, as these were most effective in suppressing RelA expression, and the knock-down level of RelA mRNA was determined in these clones (B). RelA mRNA expression was determined by real-time RT-qPCR. Means and SD of three independent experiments with each three replicates are shown.

As the selected HEK shRNA RelA clone showed a remaining RelA expression of $\sim 17 \%$, the effect of this residual level on basal expression (Table 1 ) and on TNF- $\alpha$-induced expression of NF- $\mathrm{kB}$ target genes (Table 2) was analyzed.

Table 1. Basal gene expression in HEK shRNA RelA cells compared to the original cell line HEK-pNF-kB-d2EGFP/Neo L2 using the RT2 Profiler PCR array *.

\begin{tabular}{ccc}
\hline Gene Symbol & Description & Relative Gene Expression $(\boldsymbol{\mu} \pm$ SE) \\
\hline CCL5 & Chemokine (C-C motif) ligand 5 & $15.57 \pm 8.77$ \\
CCND1 & Cyclin D1 & $-2.99 \pm 0.05$ \\
IL8/CXCL8 & Interleukin-8 & $-8.12 \pm 5.20$ \\
GADD45B & Growth arrest and DNA-damage-inducible, beta & $3.63 \pm 1.08$ \\
JUN & Jun oncogene & $4.96 \pm 1.85$ \\
RELA & V-rel reticuloendotheliosis viral oncogene homolog A & $-4.93 \pm 0.02 * *$ \\
\hline
\end{tabular}

* The table shows all genes from both the customized and the NF- $\mathrm{B}$ signaling array, that are more than threefold up- or downregulated in HEK shRNA RelA cells compared to HEK-pNF-kB- d2EGFP/Neo L2 cells. 162 genes were investigated. Mean $(\mu)$ and standard error (SE) of the expression level were calculated from up to five independent experiments with untreated cells. Prior to investigating gene expression with $\mathrm{RT}^{2}$ Profiler $^{\mathrm{TM}}$ PCR arrays, a proper RNA and cDNA quality was confirmed. ${ }^{* *}$ Five times less RelA mRNA in the HEK shRNA RelA cells compared to the HEK-pNF-kB-d2EGFP/Neo L2 cells results in a reduction of the expression level of $100 \%$ to $20 \%$ with a downregulation of $80 \%$. This knock-down level is in line with the $87 \%$ observed using the RelA primer assays before. The complete data set is shown in Table A3. 
Table 2. TNF- $\alpha$ * induced gene expression in HEK shRNA RelA cells (RelA k.d.) compared to the original cell line HEK-pNF-kB-d2EGFP/Neo L2 (HEK wt) using the RT2 Profiler PCR array **.

\begin{tabular}{|c|c|c|c|}
\hline \multirow[t]{2}{*}{ Gene Symbol } & \multirow[t]{2}{*}{ Description } & \multicolumn{2}{|c|}{ Relative Gene Expression } \\
\hline & & HEK wt & RelA k.d. \\
\hline$B I R C 3$ & Baculoviral IAP repeat containing 3 & $4.76 \pm 0.98$ & $2.03 \pm 0.47$ \\
\hline $\mathrm{C} 3$ & Complement component 3 & $5.97 \pm 1.39$ & $1.97 \pm 0.57$ \\
\hline CCL2 & Chemokine (C-C motif) ligand 2 & $3.04 \pm 0.24$ & $-1.28 \pm 0.09$ \\
\hline CCL11 & Chemokine (C-C motif) ligand 11 & $3.73 \pm 1.51$ & $1.84 \pm 0.57$ \\
\hline CCL5 & Chemokine (C-C motif) ligand 5 & $4.79 \pm 1.79$ & $29.02 \pm 12.66$ \\
\hline$C D 69$ & CD69 molecule & $3.37 \pm 0.23$ & $-1.15 \pm 0.04$ \\
\hline CD83 & CD83 molecule & $5.68 \pm 0.82$ & $1.67 \pm 0.08$ \\
\hline CXCL1 & Chemokine (C-X-C motif) ligand 1 & $47.46 \pm 11.75$ & $-1.05 \pm 0.08$ \\
\hline CXCL10 & Chemokine (C-X-C motif) ligand 10 & $23.38 \pm 5.72$ & $-1.18 \pm 0.06$ \\
\hline CXCL2 & Chemokine (C-X-C motif) ligand 2 & $18.29 \pm 3.92$ & $1.72 \pm 0.33$ \\
\hline EXO1 & Exonuclease 1 & $1.97 \pm 0.67$ & $-4.92 \pm 0.02$ \\
\hline IL1R2 & Interleukin 1 receptor, type II & $4.02 \pm 1.29$ & $1.71 \pm 0.30$ \\
\hline IL8/CXCL8 & Interleukin-8 & $17.83 \pm 5.19$ & $2.39 \pm 0.50$ \\
\hline IRF1 & Interferon regulatory factor 1 & $3.16 \pm 0.40$ & $1.29 \pm 0.11$ \\
\hline MMP9 & Matrix metallopeptidase 9 & $3.34 \pm 0.61$ & $2.01 \pm 0.37$ \\
\hline NFKBIA & Nuclear factor of kappa light polypeptide gene enhancer in B-cells inhibitor, alpha & $11.88 \pm 1.66$ & $1.22 \pm 0.04$ \\
\hline PLAU & Plasminogen activator, urokinase & $3.35 \pm 0.57$ & $2.64 \pm 0.58$ \\
\hline PTGS2 & Prostaglandin-endoperoxide synthase 2 & $3.99 \pm 0.53$ & $2.17 \pm 0.39$ \\
\hline TNF & Tumor necrosis factor & $60.95 \pm 12.42$ & $3.40 \pm 0.54$ \\
\hline TNFRSF1B & Tumor necrosis factor receptor superfamily, member $1 \mathrm{~B}$ & $1.49 \pm 0.34$ & $4.13 \pm 2.29$ \\
\hline
\end{tabular}

* Cells were treated for $6 \mathrm{~h}$ with $10 \mathrm{ng} / \mathrm{mL} \mathrm{TNF}-\alpha .{ }^{* *}$ The table shows all genes from both, the customized and the NF- $\mathrm{KB}$ signaling array, that are more than threefold up- or downregulated (in bold) in HEK shRNA RelA cells compared to HEK-pNF-kB-d2EGFP/Neo L2 cells. 162 genes were investigated. The mean of the fold up- or downregulation was calculated from up to two independent experiments with untreated cells. Prior to investigating gene expression with $\mathrm{RT}^{2}$ Profiler ${ }^{\mathrm{TM}} \mathrm{PCR}$ arrays, a proper RNA and cDNA quality was confirmed. The complete data set is shown in Table A4.

As expected, RelA mRNA was downregulated. In addition, cyclin D1 and IL-8 expression were reduced in HEK shRNA RelA cells compared to the parental cell line (Table 1). The expression of CCL5, GADD45B and Jun was increased in cells with RelA downregulation.

Incubation with TNF- $\alpha$ induced a large set of NF- $\mathrm{KB}$ target genes in HEK cells, with highest expression of TNF, IL8, CXCL1, 2 and 10, and NF-kappa-B inhibitor alpha (NFKBIA) (Table 2). RelA knock-down nearly completely abolishes the TNF- $\alpha$-induced expression of all these target genes except CCL5. EXO1 which is not a NF- $\mathrm{kB}$ target gene is downregulated when RelA is knocked down.

Furthermore, NF-kB-dependent reporter gene expression was determined. The basal level of d2EGFP expression was unchanged compared to the parental cell lines and to cells stably transfected with a shRNA control plasmid with a random sequence (Figure 4A). TNF- $\alpha$ - and X-ray-induced d2EGFP expression were significantly reduced in HEK shRNA RelA cells compared to the parental cell line as well as to the shRNA control cell line ( $p \leq 0.05$, Figure $4 \mathrm{~A})$. The reactions of the parental cell line and the shRNA control cell line were not significantly different in no case based on a $p=2 \alpha$ level of $<0.05$. Carbon ion induced d2EGFP expression was completely abolished (Figure 4B). 

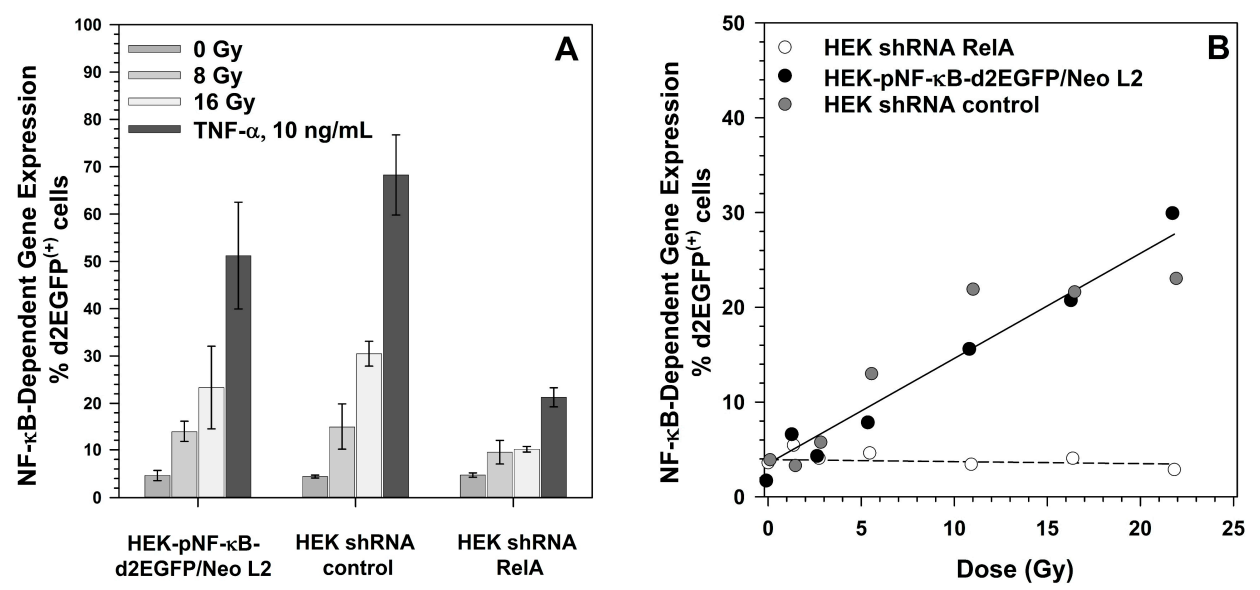

Figure 4. Effect of RelA knock-down on NF- $\mathrm{BB}$ activation by X-rays and TNF- $\alpha$ (A), and by carbon ions (B). HEK-pNF- $k$ B-d2EGFP/Neo L2 cells, cells stably transfected with the shRNA control vector (HEK shRNA control) or the RelA shRNA plasmid (HEK shRNA RelA) were seeded in petri dishes, grown for two days, and exposed to X-rays $(200 \mathrm{kV}$, LET $\sim 0.3-3 \mathrm{keV} / \mu \mathrm{m})$, incubated with $10 \mathrm{ng} / \mathrm{mL}$ TNF- $\alpha$ (A) or irradiated with ${ }^{13} \mathrm{C}$-ions $(75 \mathrm{MeV} / \mathrm{n}$, LET $34 \mathrm{keV} / \mu \mathrm{m}) .18 \mathrm{~h}$ after exposure, cells were harvested by trypsination, fixed with $3.5 \%$ formaldehyde and the percentage of $\mathrm{d}_{2} \mathrm{EGFP}^{(+)}$cells was determined by flow cytometry.

\subsection{Growth of RelA Knock-Down Cells}

In order to determine whether RelA knock-down affects basic cellular functions such as growth, cell numbers were counted during a growth period of 10 days. HEK shRNA RelA cells showed a prolonged lag phase compared to HEK-pNF-kB-d2EGFP/Neo clone L2 cells (Figure 5). Once proliferation starts, both cell lines grow with the same velocity.

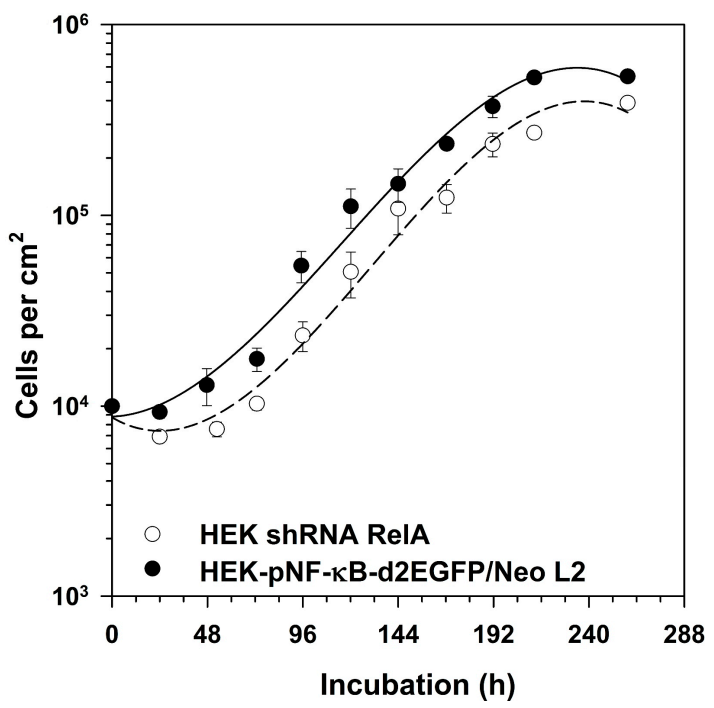

Figure 5. Growth kinetics of HEK shRNA RelA cells compared to the original cell line. $10^{4} \mathrm{cells} / \mathrm{cm}^{2}$ HEK-pNF-kB-d2EGFP/Neo L2 cells and cells stably transfected with the RelA shRNA plasmid (HEK shRNA RelA) were seeded in petri dishes. On a daily base, cells were harvested by trypsination and counted in a counting chamber. The graph shows means and standard errors of three independent experiments. 


\subsection{Survival of RelA Knock-Down Cells After X-ray and after Heavy Ion Exposure}

The survival curves after exposure of HEK-pNF-kB-d2EGFP/Neo clone L2 cells and HEK shRNA RelA cells were of curvilinear shape (Figure 6). The curve of the RelA knock-down cells is significantly steeper, indicating a higher radiosensitivity. The $\mathrm{D}_{0}$ indicating the dose necessary to reduce survival of HEK cells to $37 \%$ is 1.12 Gy for the parental cell line compared to 0.82 Gy for the RelA knock-down cells (Table 3).

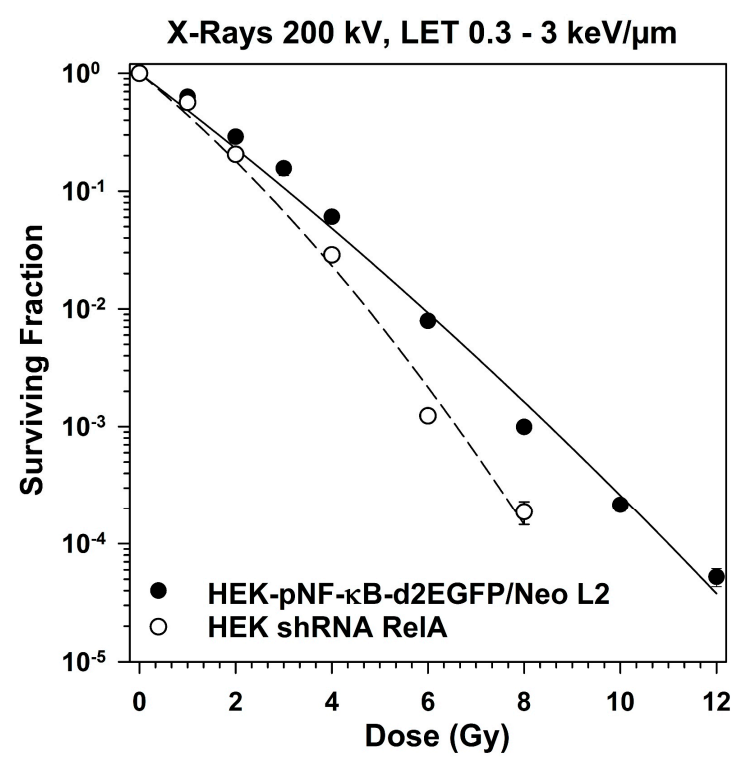

Figure 6. Clonogenic survival of HEK cells with RelA knock-down compared to the parental cells after X-irradiation (200 kV). HEK-pNF-kB-d2EGFP/Neo L2 and HEK shRNA RelA cells were irradiated, incubated and colonies were fixed after 14 to 21 days (means \pm SE of 7-13 independent experiments with six replicates each).

Table 3. Parameters of the survival curves *.

\begin{tabular}{|c|c|c|c|c|c|c|c|c|}
\hline \multirow[b]{2}{*}{$\begin{array}{l}\text { Radiation } \\
\text { Quality }\end{array}$} & \multirow[b]{2}{*}{$\begin{array}{c}\text { LET } \\
(\mathrm{keV} / \mu \mathrm{m})\end{array}$} & \multicolumn{2}{|c|}{$\mathrm{D}_{0}(\mathrm{~Gy})$} & \multicolumn{2}{|c|}{$n$} & \multicolumn{2}{|c|}{$D_{q}(G y)$} & \multirow{2}{*}{$\begin{array}{l}\text { Significance } \\
\text { Level for } D_{0} \\
\quad p=2 \alpha\end{array}$} \\
\hline & & HEK wt & RelA k.d. & HEK wt & RelA k.d. & HEK wt & RelA k.d. & \\
\hline X-rays & $0.3-3$ & $1.20 \pm 0.05$ & $0.76 \pm 0.04$ & $1.31 \pm 0.84$ & $2.43 \pm 1.06$ & $0.33 \pm 0.71$ & $0.68 \pm 0.33$ & $<0.005$ \\
\hline${ }^{12} \mathrm{C}$ & 10 & $1.03 \pm 0.14$ & $0.91 \pm 0.22$ & $1.17 \pm 0.34$ & $1.64 \pm 1.15$ & $0.15 \pm 0.36$ & $0.34 \pm 0.71$ & 0.6006 \\
\hline${ }^{28} \mathrm{Si}$ & 55 & $0.47 \pm 0.05$ & $0.38 \pm 0.04$ & $1.28 \pm 0.34$ & $1.31 \pm 0.12$ & $0.12 \pm 0.14$ & $0.10 \pm 0.12$ & 0.1923 \\
\hline${ }^{58} \mathrm{Ni}$ & 175 & $0.53 \pm 0.02$ & $0.61 \pm 0.04$ & $1.0 \pm 0.26$ & $0.73 \pm 0.26$ & $0.0 \pm 0.12$ & $-0.19 \pm 0.19$ & 0.0607 \\
\hline${ }^{36} \mathrm{Ar}$ & 271 & $0.72 \pm 0.09$ & $0.68 \pm 0.08$ & $0.82 \pm 0.36$ & $1.11 \pm 0.29$ & $-0.14 \pm 0.27$ & $0.08 \pm 0.19$ & 0.8371 \\
\hline
\end{tabular}

* For cellular survival data the parameters $\mathrm{D}_{0}$ and $\mathrm{n}$ of the dose effect curve were calculated by regression analysis (survival versus dose) and fitted to the equation $\mathrm{S}=1-\left(1-\exp ^{\mathrm{D} / \mathrm{Do}}\right)^{n}$. The comparison of different survival curves were performed by Student's t-test of the regression coefficients. A $p=2 \alpha$ level of $<0.05$ was considered as significant. Comparison of two regression lines for HEK-pNF-kB-d2EGFP/Neo L2 and HEK shRNA RelA cells is based on the hypothesis $\left(\sigma^{2} \mathrm{yx}\right)_{1} \neq\left(\sigma^{2} \mathrm{yx}\right)_{2}$ for $\mathrm{D}_{0} ; \mathrm{P}$, probability.

High-LET radiation exposure of HEK cells results in purely exponential survival curves (Figure 7). Based on energy dose, heavy ions with an LET of $55 \mathrm{keV} / \mu \mathrm{m}$ are most efficient in cell killing (Figure 7A), while radiation qualities with an LET above or below this range are less efficient in cell killing (Figure 7A,B). The $\mathrm{D}_{0}$ first decreases to $0.47 \mathrm{~Gy}$ for silicon ions, then increases with increasing LET to 0.72 Gy for argon ions (Table 3). 

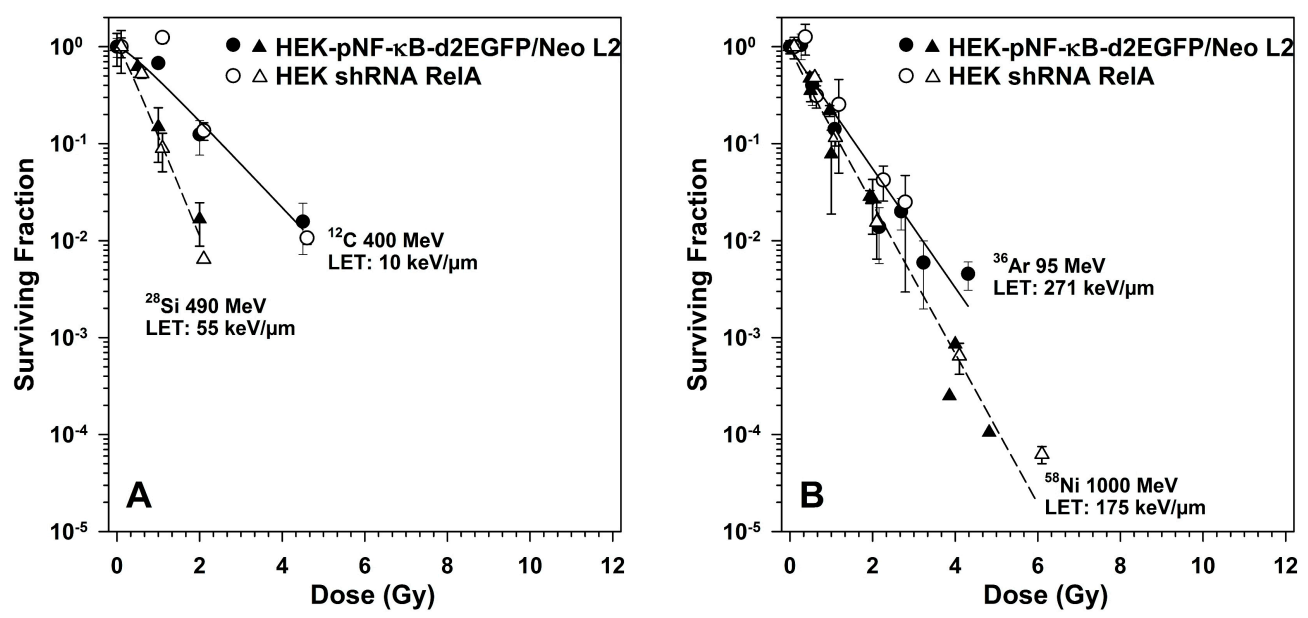

Figure 7. Clonogenic survival of HEK cells with RelA knock-down compared to the parental cells after exposure to heavy ions of diffent LET (A), linear energy transfer (LET) $<100 \mathrm{keV} / \mu \mathrm{m}$, (B) $\mathrm{LET}>100 \mathrm{keV} / \mu \mathrm{m}$ ). HEK-pNF-кB-d2EGFP/Neo L2 and HEK shRNA RelA cells were irradiated, incubated and colonies were fixed after 14-21 days (means \pm SE of 1-2 independent experiments with each six replicates).

\subsection{Induction of NF-kB Target Gene Expression by Exposure to Different Radiation Qualities}

As NF-kB was weakly activated by X-rays and activated by heavy ions to a higher extent, dependent on LET, but only for X-rays, a reduction of survival in case of RelA downregulation was observed, the expression of $88 \mathrm{NF}-\mathrm{kB}$ target genes was profiled $6 \mathrm{~h}$ after exposure to $\mathrm{X}$-rays and heavy ions (Table 4).

The expression of chemokines and cytokines was upregulated by low- and high-LET radiation at higher doses. Exposure to $0.5 \mathrm{~Gy} \mathrm{X}$-rays or Ti ions did not significantly up-regulate the expression of the investigated NF- $\mathrm{kB}$ target genes. The chemokine and cytokine expression was in general higher after exposure to $4 \mathrm{~Gy}$ Ti ions compared to $4 \mathrm{~Gy} \mathrm{X}$-rays. The highest expression levels were reached for CXCL10 and TNF.

Adhesion molecules such as VCAM- 1 and a costimulatory factor (CD83) were also induced. Components of the NF- $\mathrm{kB}$ pathway such as NFKB2 and the inhibitor NFKBIA were upregulated by the two radiation qualities.

RelA knock-down inhibited the ionizing radiation-induced NF- $\mathrm{kB}$ target gene expression except for TNFRSF1B.

\subsection{Secretion of TNF- $\alpha$ and IL-8 after X-Irradiation}

The secretion of the cytokines GM-CSF, IFN- $\gamma$, IL-1 $\beta$, IL-2, IL-4, IL-5, IL-6, IL-8, IL-10, IL-12(p70) and TNF- $\alpha$ was determined using a multiplex ELISA. Only IL- 8 and TNF- $\alpha$ reached values above the quantification limit of the assay.

Incubation with TNF- $\alpha$ resulted in strong secretion of IL-8 by HEK-pNF-kB-d2EGFP/Neo L2 cells within $12 \mathrm{~h}$, and the IL-8 concentration in the cell culture supernatants further increased within the next $36 \mathrm{~h}$ (Figure 8A). High doses of X-rays ( 8 and $16 \mathrm{~Gy}$ ) are required to induce significant IL-8 secretion $12 \mathrm{~h}$ after irradiation, and this secretion is further enhanced at later time points ( $24 \mathrm{~h}$ and $48 \mathrm{~h}$ ). In HEK shRNA RelA cells, the level of IL-8 secretion in mock-irradiated cells (0 Gy) is lower compared to HEK-pNF-kB-d2EGFP/Neo L2 cells, and only the highest X-ray dose (16 Gy) and incubation with TNF- $\alpha$ provoke a very slight time-dependent increase in IL-8 secretion (Figure $8 \mathrm{~B}$ ). 
Table 4. Relative gene expression in HEK-pNF-кB-d2EGFP/Neo L2 (HEK wt) and HEK shRNA RelA (RelA k.d.) cells after irradiation * using the RT2 Profiler PCR array **. The complete data sets are shown in Tables A5 and A6.

\begin{tabular}{|c|c|c|c|c|c|c|c|c|c|c|}
\hline \multirow{3}{*}{$\begin{array}{c}\text { Radiation Quality } \\
\text { Dose (Gy) } \\
\text { Gene Symbol/Cell Line }\end{array}$} & \multicolumn{6}{|c|}{ X-rays } & \multicolumn{4}{|c|}{${ }^{48} \mathrm{Ti}$ ions } \\
\hline & \multicolumn{2}{|c|}{0.5} & \multicolumn{2}{|c|}{4.0} & \multicolumn{2}{|c|}{8.0} & \multicolumn{2}{|c|}{0.5} & \multicolumn{2}{|c|}{4.0} \\
\hline & HEK wt & RelA k.d. & HEK wt & RelA k.d. & HEK wt & RelA k.d. & HEK wt & RelA k.d. & HEK wt & RelA k.d. \\
\hline CCL5 & $-1.42 \pm 0.24$ & $1.55 \pm 0.68$ & $3.68 \pm 1.53$ & $2.07 \pm 0.90$ & $3.34 \pm 1.40$ & $-1.47 \pm 0.30$ & $-1.97 \pm 0.17$ & $-1.89 \pm 0.23$ & $-1.56 \pm 0.22$ & $1.22 \pm 0.53$ \\
\hline$C D 83$ & $-1.01 \pm 0.03$ & $1.12 \pm 0.06$ & $2.47 \pm 0.08$ & $1.67 \pm 0.08$ & $3.75 \pm 0.18$ & $2.27 \pm 0.11$ & $1.25 \pm 0.04$ & $1.09 \pm 0.05$ & $4.37 \pm 0.14$ & $1.42 \pm 0.07$ \\
\hline CXCL1 & $1.04 \pm 0.20$ & $1.06 \pm 0.09$ & $3.57 \pm 0.56$ & $1.52 \pm 0.12$ & $6.96 \pm 1.01$ & $2.02 \pm 0.16$ & $1.01 \pm 0.19$ & $-1.48 \pm 0.05$ & $7.55 \pm 1.44$ & $1.21 \pm 0.10$ \\
\hline CXCL2 & $-1.35 \pm 0.13$ & $-1.04 \pm 0.19$ & $2.33 \pm 0.33$ & $1.55 \pm 0.30$ & $3.01 \pm 0.40$ & $1.29 \pm 0.25$ & $1.30 \pm 0.22$ & $1.11 \pm 0.21$ & $3.48 \pm 0.59$ & $1.00 \pm 0.19$ \\
\hline CXCL10 & $-1.10 \pm 0.16$ & $1.05 \pm 0.08$ & $4.68 \pm 0.60$ & $2.23 \pm 0.16$ & $14.58 \pm 2.57$ & $2.04 \pm 0.15$ & $-1.27 \pm 0.14$ & $-1.30 \pm 0.06$ & $6.70 \pm 1.20$ & $-1.15 \pm 0.06$ \\
\hline CXCL8/IL8 & $-1.73 \pm 0.19$ & $1.20 \pm 0.19$ & $2.42 \pm 0.66$ & $1.38 \pm 0.22$ & $3.74 \pm 0.86$ & $1.01 \pm 0.16$ & $1.38 \pm 0.44$ & $-1.26 \pm 0.13$ & $6.10 \pm 1.96$ & $1.44 \pm 0.23$ \\
\hline NFKB2 & $1.01 \pm 0.12$ & $1.09 \pm 0.18$ & $2.93 \pm 0.33$ & $1.48 \pm 0.24$ & $4.07 \pm 0.45$ & $1.62 \pm 0.26$ & $-1.25 \pm 0.09$ & $-1.02 \pm 0.16$ & $2.52 \pm 0.29$ & $1.04 \pm 0.17$ \\
\hline NFKBIA & $-1.07 \pm 0.08$ & $-1.13 \pm 0.10$ & $2.65 \pm 0.34$ & $1.47 \pm 0.17$ & $4.26 \pm 0.40$ & $1.69 \pm 0.19$ & $-1.11 \pm 0.08$ & $1.05 \pm 0.12$ & $3.55 \pm 0.31$ & $1.47 \pm 0.17$ \\
\hline TNF & $1.01 \pm 0.11$ & $1.08 \pm 0.05$ & $5.10 \pm 0.99$ & $1.17 \pm 0.06$ & $12.90 \pm 1.72$ & $1.15 \pm 0.05$ & $1.08 \pm 0.12$ & $-1.26 \pm 0.04$ & $6.72 \pm 0.76$ & $-1.12 \pm 0.04$ \\
\hline TNFRSF1B & $-1.81 \pm 0.16$ & $-2.15 \pm 0.26$ & $1.02 \pm 0.22$ & $4.10 \pm 2.28$ & $1.11 \pm 0.22$ & $2.39 \pm 1.33$ & $1.07 \pm 0.30$ & $2.88 \pm 1.60$ & $-2.04 \pm 0.14$ & $-2.65 \pm 0.21$ \\
\hline VCAM1 & $-1.27 \pm 0.20$ & $1.08 \pm 0.05$ & $4.24 \pm 1.56$ & $1.17 \pm 0.06$ & $2.94 \pm 0.87$ & $1.15 \pm 0.05$ & $-1.77 \pm 0.15$ & $-1.26 \pm 0.04$ & $-1.10 \pm 0.24$ & $-1.12 \pm 0.04$ \\
\hline
\end{tabular}

${ }^{*}$ Exposure to X-rays or ${ }^{48} \mathrm{Ti}$-ions $(1000 \mathrm{MeV} / \mathrm{n}$, LET $108 \mathrm{keV} / \mu \mathrm{m}) .{ }^{* *}$ The table shows all genes from the NF- $\mathrm{kB}$ signaling array, that are more than threefold up- or down-regulated (in

bold) in irradiated cells compared to mock-irradiated cells. The mean of the fold up- or downregulation was calculated from up to two independent experiments with untreated cells.

Prior to investigating gene expression with RT2 Profiler ${ }^{\mathrm{TM}}$ PCR arrays, a proper RNA and cDNA quality was confirmed. ACTB, B2M, GAPDH, HPRT1 and RPLP0 were used as reference

genes to normalize the results. 

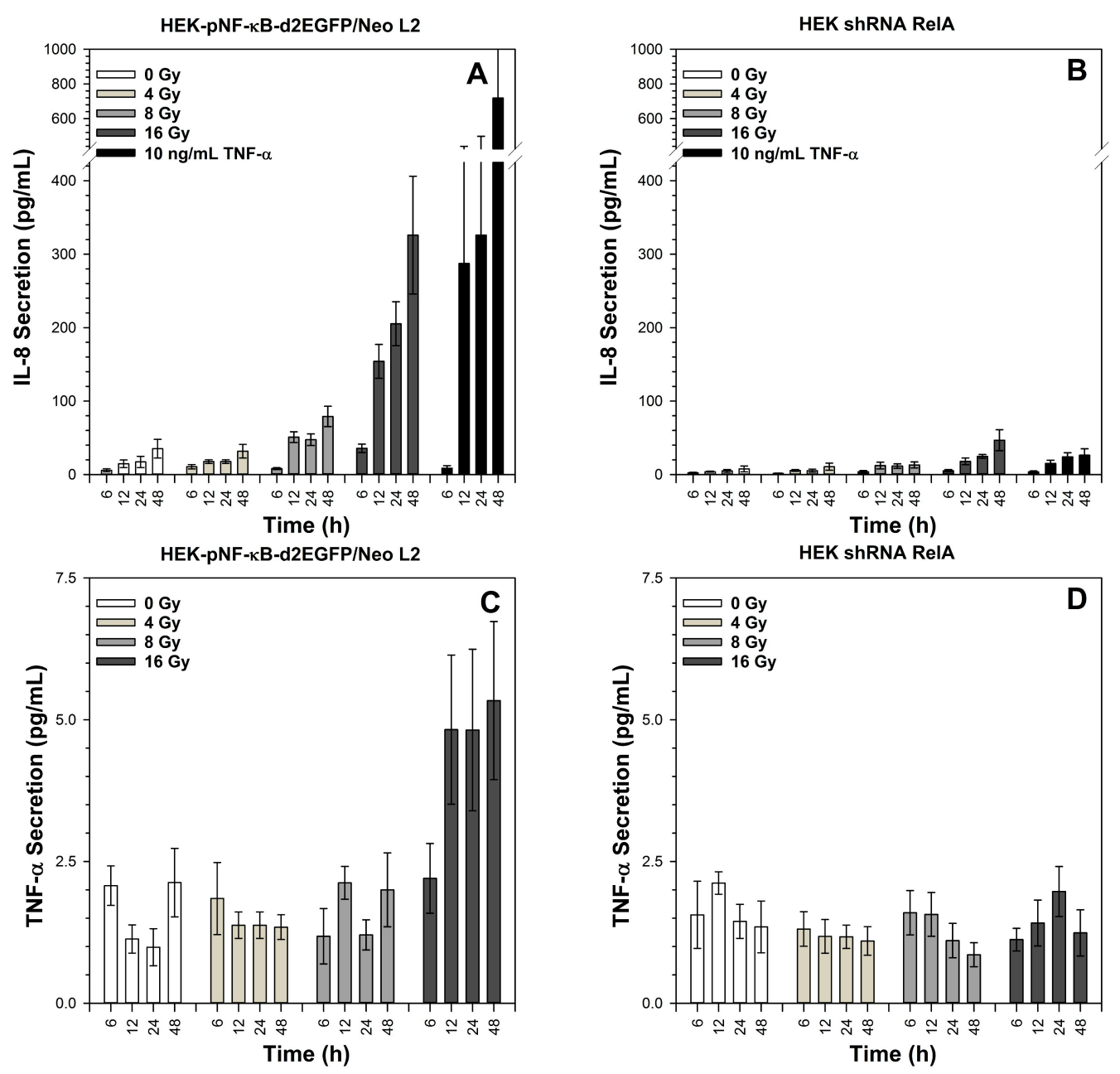

Figure 8. Kinetics of IL-8 and TNF- $\alpha$ secretion of HEK-pNF-кB-d2EGFP/Neo L2 (A,C) and HEK shRNA RelA cells (B,D) after X-irradiation. The supernatants were collected at the indicated time points. The TNF- $\alpha$ and IL- 8 content of the supernatants was determined by means of a multiplex ELISA. Mean and standard error of three independent experiments with duplicate cytokine determination are shown.

TNF- $\alpha$ secretion increased $12 \mathrm{~h}$ after exposure of HEK-pNF-kB-d2EGFP/Neo L2 cells to 16 Gy $X$-rays and remained elevated during the investigated time period without further significant increase (Figure $8 \mathrm{C}$ ). The total amount was much lower compared to IL-8. For HEK shRNA RelA cells, TNF- $\alpha$ secretion remained within background levels for all applied doses and incubation periods (Figure 8D). TNF- $\alpha$ secretion induced by incubation with TNF- $\alpha$ is not shown, as the added TNF- $\alpha$ was present in the supernatants and disguised the TNF- $\alpha$ secretion of the cells.

\section{Discussion}

In this study, we show that knock-down of the NF-kB subunit RelA results in sensitization of HEK cells towards low-LET X-rays, but not towards heavy ions in a LET range of 10 to $272 \mathrm{keV} / \mu \mathrm{m}$. It was previously demonstrated that heavy ions in the LET range of 91 to $272 \mathrm{keV} / \mu \mathrm{m}$ strongly activate NF- $\mathrm{BB}$ [20]. The NF- $\mathrm{BB}$ activation by low- and high-LET ionizing radiation was shown to be ATM dependent. Furthermore, IkB-degradation by the proteasome is essential for ionizing radiation-induced NF-kB-activation.

RelA knock-down also influenced cell proliferation, resulting in a prolonged lag phase, but it did not impact the proliferation rate once the exponential growth phase was reached. Without NF- $\kappa$ B-activation by TNF- $\alpha$ or ionizing radiation, the reduced RelA levels in the knock-down cells 
changed the expression of only a few NF-kB target genes (CCND1, CXCL8, JUN, TNF). After incubation with TNF- $\alpha$ or irradiation, the upregulation of CXCL1, 2, 8 and 10, NFKBIA and TNF was strongly reduced in RelA knock-down cells.

\subsection{Activation of the NF- $\kappa B$ Pathway by Different Radiation Qualities}

Our first study examining the effects of heavy ions on the NF-kB pathway revealed that high-LET argon ions $(272 \mathrm{keV} / \mu \mathrm{m})$ activated the sequence of all events in the NF- $\mathrm{kB}$ pathway from DNA binding via transcription to protein translation and maturation [18]. The study of the LET dependence of this cellular response to heavy ion exposure disclosed that indeed the maximal potency to activate NF-KB dependent d2EGFP gene expression in HEK cells occurs at $272 \mathrm{keV} / \mu \mathrm{m}$ (argon ions) have [20]. In accordance with the results presented here, other authors using a DNA binding assay report nuclear translocation NF- $\mathrm{kB}$ after exposure of normal human monocytes (MM6 cells) after exposure to $0.7 \mathrm{~Gy}$ of ${ }^{56} \mathrm{Fe}$ ions [29]. Activation of NF- $\kappa B$ was mediated through phosphorylation of $\mathrm{I} \kappa \mathrm{B} \alpha$ via subsequent proteasomal degradation. The study on iron ion effects on monocytes revealed only binding of NF- $\mathrm{kB}$ to its consensus sequence of $5^{\prime}$-GGGGACTTTCC- $3^{\prime}$, transcriptional activation itself was not shown.

Also in vivo, NF- $\mathrm{kB}$ activation was observed in the heart and bone marrow of mice one week, one month and six months after exposure to $300 \mathrm{MeV} / \mathrm{n}^{28} \mathrm{Si}$ ions (LET $77 \mathrm{keV} / \mu \mathrm{m}$ ) [30]. This clearly indicates that high-LET ion exposure induces rapid and persistent NF- $\mathrm{KB}$ activation in vitro and in vivo.

\subsection{NF- $\kappa B$ Activation by Ionizing Radiation Is ATM Dependent}

KU-55933 is specific for ATM with respect to inhibition of other related kinases such as DNA-dependent protein kinase (DNA-PK) or phosphatidylinositol 3'-kinase (PI3K) which required a 200 times higher concentration for their inhibition [31]. Results showed that while it was not possible to suppress TNF- $\alpha$-induced NF- $\mathrm{kB}$ activation, KU-55933 suppressed ionizing radiation-induced NF- $\mathrm{KB}$ activity completely. Increasing doses of X-rays and ${ }^{36} \mathrm{Ar}$ ions were used to induce NF- $\kappa B$, showing its dose and LET dependency, as the percentage of $\mathrm{d} 2 \mathrm{EGFP}^{(+)}$cells increased with increasing doses and ${ }^{36} \mathrm{Ar}$ ions had a higher impact on d2EGFP-dependent NF- $\mathrm{kB}$ expression than X-rays.

These results support the assumption that ionizing radiation, including high-LET heavy ions, activates the genotoxic stress induced NF-KB pathway and proves that NF- $\mathrm{KB}$ activation induced by ionizing radiation is strictly ATM dependent. ATM foci form quickly in the nuclei of human cells after exposure to carbon or iron ions and are believed to facilitate or initiate DNA double strand break (DSB) repair by Non-Homologous Endjoining (NHEJ) and Homologous Recombination (HR) [32,33]. ATM was shown to be activated in human cells to a higher extent by carbon ions (LET $290 \mathrm{keV} / \mu \mathrm{m}$ ) than by low-LET $\gamma$-rays [34]. This stronger ATM phosphorylation after heavy ion exposure might be important for the strong NF- $\mathrm{KB}$ activation that was observed in the LET range of $90-300 \mathrm{keV} / \mu \mathrm{m}$.

In contrast, TNF- $\alpha$ induced NF- $\mathrm{kB}$ activation was not impaired by KU-55933, as ATM is not involved in the classical pathway, which is activated by TNF- $\alpha$.

\subsection{IкB Degradation by the Proteasome Is Essential for TNF- $\alpha$ and Ionizing Radiation-Induced NF- $\kappa B$ Activity}

Within non-cytotoxic concentrations (viability above $80 \%$ ), MG-132 suppressed TNF- $\alpha$ - and ionizing radiation-induced NF- $\kappa B$ activity, showing that I $\kappa B$ degradation by the proteasome is an essential step in both, the genotoxic stress and the TNF- $\alpha$-induced pathway. However, it has to be considered, that disturbing proteasome functions with MG-132 leads to the loss of regulation of essential functions within the cell and these chemical inhibitors are not NF- $\mathrm{KB}$ specific.

\subsection{Role of RelA in Cell Proliferation}

Downregulation of RelA prolonged the lag phase. Furthermore, cells required a longer recovery period after freezing and thawing, indicating a role of RelA in cell proliferation. This is supported by the 
observation that transfection of NF- $\mathrm{kB} /$ RelA antisense oligodeoxynucleotide reduces the proliferation of SGC-7901 gastric cancer cells [35] and that siRNA-mediated RelA knock-down decreased the proliferation ability of human esophageal squamous cell cancer (ESCC) EC9706 cells [36]. In tumor cells, the inhibiting effect of RelA knock-down seems to be much more pronounced compared to HEK cells. This might be explained by a constitutive NF-KB activation in many tumors, e.g., some gliomas [37] and hepatomas [38], which is then suppressed. In breast cancer cells, transfection of RelA shRNA reduced proliferation [39].

The reduced expression of cyclin D1 (-3.0) is a possible explanation for the effects of RelA knock-down on proliferation, as RelA and JunD were shown to cooperate to activate the proximal $\mathrm{kB}$ site of the cyclin D1 promoter in presence of serum [40]. Cyclin D1 regulates the cyclin-dependent kinases CDK4 or CDK6, the activity of which is required for cell cycle G1/S transition. This connection of NF- $\mathrm{KB}$, cyclin D1 and proliferation was also found in neural stem or progenitor cells (NSCs, NPCs) [41] and fibroblasts [42]. Upregulation of the activated protein 1 (AP-1) family member Jun (5.0) in HEK shRNA RelA cells might be a regulatory mechanism to compensate for the RelA loss, as c-Jun affects cell proliferation, migration and invasion and, like NF- $\mathrm{KB}$, actively participates in tumorigenesis [43].

\subsection{Role of RelA in Clonogenic Survival after Exposure to Different Radiation Qualities}

As activation of the NF- $\mathrm{KB}$ pathway is supposed to play a role in the negative regulation of apoptosis, survival of cells with residual DNA damage might thus be favored after irradiation. Even if this happens only in rare cases after ionizing radiation exposure, it might result in initiation or promotion of cancer from such wise affected cells. Cellular responses which may be related to better survival of exposed cells would contribute considerably to astronauts' radiation risk, especially at low doses when transient induction of genes involved in maintaining DNA fidelity and in modulating cell cycle progression and cell death would occur [44]. As heavy ion exposure strongly activated NF- $k B$, we examined whether NF- $\mathrm{kB}$ gives HEK cells a survival advantage after heavy ion exposure. For this purpose, expression of the NF-kB subunit RelA was downregulated by stable transfection of RelA shRNA.

The colony forming ability test showed that HEK cells were more sensitive to X-irradiation when RelA was downregulated. Such sensitization to X-rays was also observed with chemical NF- $\mathrm{B}$ B inhibitors, e.g., the sesquiterpene lactone parthenolide, an I $\kappa B$ kinase (IKK) inhibitor, inhibited constitutive and radiation-induced NF- $\mathrm{KB}$ binding activity in p53 null PC-3 cells and enhanced their X-ray sensitivity by a dose modification factor of 1.7 [45]. RelA knock-out murine embryonic fibroblasts (MEF $\mathrm{p} 65^{-/-}$) were 1.3-fold more sensitive towards X-rays than the $\mathrm{p} 65^{+/+}$ cells [46]. In many cancer cell types, NF- $\mathrm{KB}$ inhibition sensitized the cells to ionizing radiation [47-50].

In these MEF $\mathrm{p} 65^{-/-}$cells, the killing effect of UVB radiation was lower compared to MEF

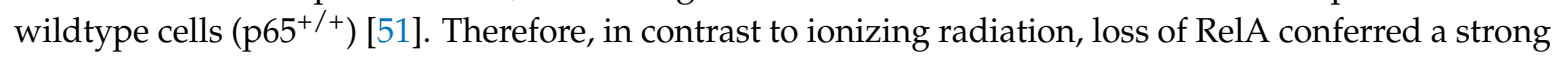
resistance to UVB-induced cell death which was accompanied by reduced Gadd45 gene expression [51].

In contrast to the sensitization to X-rays by RelA knock-down, the sensitivity to heavy ion exposure was equal or only slightly different for cells with and without RelA over a wide range of LET $(10-271 \mathrm{keV} / \mu \mathrm{m})$. This indicates that RelA and heavy ion induced NF- $\mathrm{KB}$ activation does not procure a survival advantage for the exposed cells. This might be explained by other pro-death signals of the heavy ion exposure. Interestingly, in human hematopoietic stem and progenitor cells (HSPC) and peripheral blood lymphocytes (PBL), inhibition of NF- $\mathrm{kB}$ activation by expression of a super-repressor variant of $I \kappa B \alpha(I \kappa B \alpha-S R)$ altered DNA double-strand-break repair [52]. I $K B \alpha$-SR expression reduced homologous DSB repair in PBL by 33\% [52]. NHEJ of DNA DSBs was compromised in HSPC and PBL (reduction to $37 \%$ and $52 \%$, respectively) [52]. These measurements were performed on enzymatically induced DNA DSBs, results for low- or even high-LET radiation-induced DSBs are not yet available. Nevertheless, reduced DNA DSB repair in case of NF- $\mathrm{kB}$ repression or down-regulation might play a role for survival after ionizing radiation exposure. Delayed or incomplete repair might override other 
NF- $\mathrm{kB}$ induced survival signals. Another explanation for the missing effect of RelA knockdown might be the high-LET which is in the range of the highest observed biological efficiency. The cell killing effect in the LET range of $100-200 \mathrm{keV} / \mu \mathrm{m}$ is already very high, so that disturbed cellular signaling pathways might not be able to further increase cell killing. This was observed for the pro-apoptotic p53 in some cell systems: apoptosis was independent of the p53 status [53,54].

Comparing ionizing radiation and chemotherapeutics such as the topoisomerase II inhibitor doxorubicin, knock-down of RelA by siRNA increased the killing effect of doxorubicin in HepG2 cells [38]. The authors of this publication explain the increased killing of hepatoma cells by lower NF- $\mathrm{KB}$-mediated expression of multi-drug resistance (MDR1) gene [38]. A mechanism based on MDR1 is not likely to influence survival after ionizing radiation. In nude mice bearing HeLa cervical cancer xenografts, downregulation of p65 via photothermal transfection of p65 siRNA increased irinotecan-induced tumor apoptosis [55].

Furthermore, the NF- $\mathrm{kB}$ target gene expression profile might be different for low- and high-LET radiation exposure and might give an explanation for the different role in the cellular radiation response. Therefore, the expression of 88 target genes was determined after X-ray and heavy ion exposure. Genes that are regulated more than threefold and at the same time are controlled by RelA are discussed below.

\subsection{Role of RelA in the Expression of NF- $\mathrm{B} B$ Target Genes after Exposure to Different Radiation Qualities}

NF- $\mathrm{kB}$ target genes that are induced after irradiation affect intercellular communication and many of them are proinflammatory. e.g., TNF- $\alpha$ activates inflammation by inducing a proinflammatory cytokine cascade, mediated through expression of IL8 [56]. Incubation with TNF- $\alpha$ induces the expression of a larger subset of genes than low- or high-LET irradiation at a dose of 4 Gy (Figure 9A). TNF, CXCL1 and -10 are upregulated by TNF- $\alpha, 4$ Gy X-rays and $4 \mathrm{~Gy}$ Ti ions. A higher X-ray dose (8 Gy) increased the overlap in the subset of induced NF- $\mathrm{kB}$ target genes (Figure 9B). The gene subsets show overlap with those determined in osteosarcoma cells [57].

The overlapping gene expression in HEK-pNF-kB- d2EGFP/Neo L2 cells after TNF- $\alpha$ and radiation treatment was not observed in RelA knock-down cells, confirming the role of the NF- $\mathrm{KB}$ subunit RelA in the expression of these genes.

After TNF- $\alpha$ treatment HEK-pNF-KB-d2EGFP/Neo L2 cells but not in HEK shRNA RelA cells showed a clear upregulation of $\mathrm{C}-\mathrm{X}-\mathrm{C}$ motif $(\mathrm{CXC}, \mathrm{C}$ stands for cysteine, $\mathrm{X}$ for any other amino acid) chemokine genes, including CXCL1, CXCL10, CXCL2 (MIP-2) and CXCL8 (IL8). The CXC chemokines belong to one group of small cytokines, which, when they are are secreted by infected cells act as chemoattractants inducing chemotaxis or migration especially of neutrophils, which are the first responders during inflammation to migrate towards site of inflammation. Additionally, in wound healing the increased chemokine concentration of damaged cells results in attracting cells to site of damage. Loss of chemokine induction is a serious impairment for the organism as it leads to dysfunctional cell migration and wound healing deficiency. The essential role of TNF in the early induction of chemokines and subsequent recruitment of leukocytes have been shown using models of mycobacterial infection [58] as induction of chemokines and cellular recruitment were delayed in $\mathrm{TNF}^{-/-}$cells. Animal studies show that CXCL2 was upregulated in murine tumors after exposure to carbon ions $(290 \mathrm{MeV} / \mathrm{n}$, LET $50 \mathrm{keV} / \mu \mathrm{m})$ [59].

As expected, TNF- $\alpha$ treatment induced high upregulation (60.0) of TNF, as TNF- $\alpha$, after being released as a response to immunological stimuli, acts as a positive autocrine feedback signal to augment NF- $\mathrm{kB}$ activation [60]. In the knock-down cell line, no upregulation of TNF was observed, as NF- $\mathrm{kB}$ is a key transcription factor involved in the synthesis of TNF- $\alpha$ [61]. 


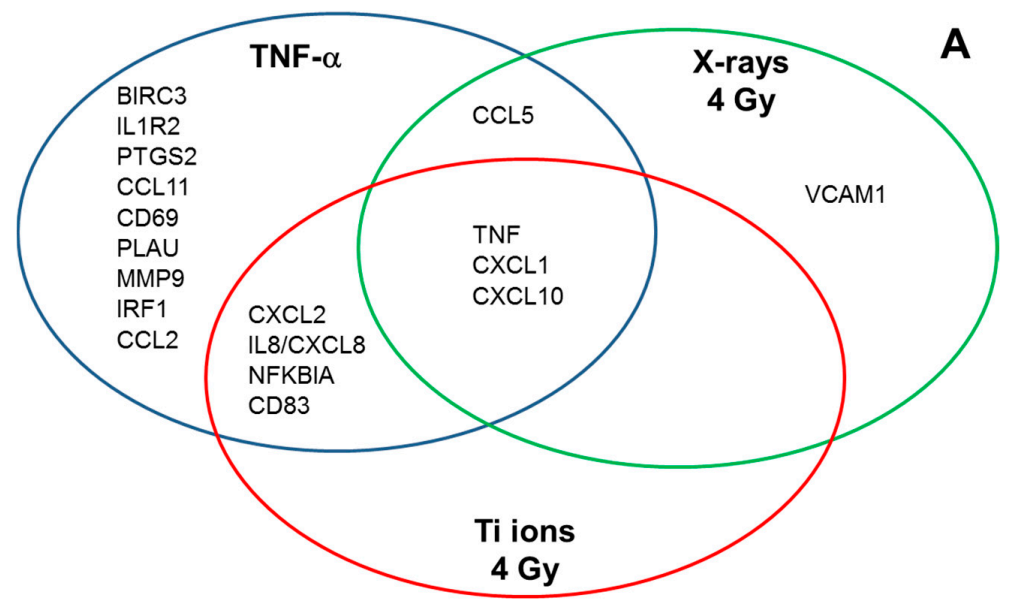

HEK-pNF-kB-d2EGFP/Neo L2 cells

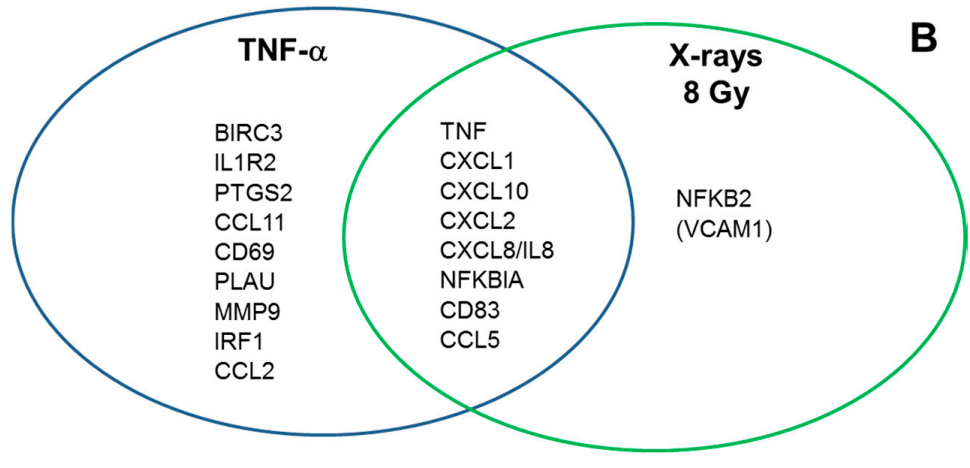

HEK-pNF-кB-d2EGFP/Neo L2 cells

Figure 9. Diagram showing the expression of NF- $\kappa \mathrm{B}$ target genes by HEK cells $6 \mathrm{~h}$ after exposure to $10 \mathrm{ng} / \mathrm{mL}$ TNF- $\alpha, 4$ Gy X-rays or 4 Gy Ti ions (A) and after exposure to $10 \mathrm{ng} / \mathrm{mL}$ TNF- $\alpha$ or 8 Gy $\mathrm{X}$-rays (B) VCAM-1 is in parentheses as its expression is just below the threshold of threefold induction.

Upregulation of NFKBIA (encoding $I \kappa B \alpha$ ) in the original cell line was expected as well, as in addition to increasing the transcription of cytokines and adhesion proteins, NF- $\mathrm{KB}$ also increases the transcription of the inhibitor $\mathrm{I} \mathrm{KB}$, thus leading to its own inactivation and subsequent termination of the response [62]. Other studies showed that NFKBIA was also upregulated in six human malignant melanoma cell lines after carbon ion exposure (290 MeV/n, LET $50 \mathrm{keV} / \mu \mathrm{m})$ [63].

Only three of the genes upregulated in HEK-pNF-kB-d2EGFP/Neo L2 cells were induced by TNF- $\alpha$ in the knock-down cell line: CCL5, TNF and TNFRSF1B. For the latter two genes, the induction factor was much lower compared to the RelA proficient cell line. Instead, downregulation of one NF- $\mathrm{kB}$ target gene was observed, EXO1. Exonuclease 1 (EXO1) is involved in DNA damage signaling [64].

The target gene array, investigating 88 genes after $\mathrm{X}$ - and ${ }^{48} \mathrm{Ti}$ ion irradiation, showed that NF-KB-dependent gene expression does not only depend on dose, but also on LET, complementing our recently published study [26] and studies with Caenorhabitidis elegans [65]. The extent of gene expression increases with increasing doses. Further, the degree of regulation is stronger after $4 \mathrm{~Gy}$ of ${ }^{48} \mathrm{Ti}$ ion exposure than after $\mathrm{X}$-irradiation of the same dose.

In HEK-pNF-kB-d2EGFP/Neo L2 cells, the set of genes, that has already been shown to be upregulated after TNF- $\alpha$ treatment, was likewise upregulated after exposure to $X$-rays and heavy ions. It includes CXC chemokines, TNF and NFKBIA which encodes the NF- $\mathrm{KB}$ inhibitor I $\mathrm{K} \mathrm{B} \alpha$. This shows that expression of these genes is activated not only by the classical NF-kB pathway, but also the genotoxic stress induced, independent of the radiation quality. 
In this work, both low- and high-LET radiation exposure resulted in upregulation of TNF, and with higher LET, the upregulation was stronger. Interestingly, in the tibial marrow of $\mathrm{Fe}$ ion $(600 \mathrm{MeV} / \mathrm{n}$, LET $174 \mathrm{keV} / \mu \mathrm{m}$ ) irradiated mice, no significant increase in TNF expression was found three days after exposure to $2 \mathrm{~Gy}$, and only a slight increase after $2 \mathrm{~Gy} \gamma$-irradiation which remained elevated through day three after irradiation [66].

Especially the CXC chemokines are strongly upregulated, in case of CXCL10 up to 14.6 fold after irradiation with $8 \mathrm{~Gy} X$-rays. None of the genes that are upregulated at higher doses in the original cell line exceeds the threshold of 3 after irradiation with $0.5 \mathrm{~Gy}$ of both, X-rays and ${ }^{48} \mathrm{Ti}$ ions. Though, after 4 Gy of X-rays, CXC chemokines reach expression values of 2.3 to 4.7 fold. For the same dose, these genes are expressed up to 7.6 fold after ${ }^{48} \mathrm{Ti}$ ion irradiation.

CCL5 has chemotactic activity for monocytes and basophils and binds to chemokine receptors CCR2 and CCR4. It was upregulated by high doses of X-rays. Such an upregulation was also observed in vivo in the bone marrow of C57BL/6J mice exposed to $2 \mathrm{~Gy} \gamma$-rays and is suggested to promote ostoclastogenesis [66].

Apart from the genes expressed after both, TNF- $\alpha$ treatment and irradiation, additional genes are upregulated only upon $\mathrm{X}$-irradiation, not after heavy ion exposure, proving the relation between radiation quality or LET and gene expression. These genes include CCL5, NFKB2, and VCAM1.

NFKB2 codes for the NF- $\mathrm{kB}$ subunit p100, which is involved in the non-canonical NF- $\mathrm{kB}$ pathway. It is processed to $\mathrm{p} 52$. This element of the non-canonical pathway seems to be upregulated only by X-rays and not by heavy ions. The RelB:p52 dimer was shown to confer radio-resistance to prostate cancer cells by upregulating the expression of the antioxidant enzyme manganese superoxide dismutase (MnSOD) [67-70]. An upregulation of RelB expression $8 \mathrm{~h}$ after $\mathrm{X}$-ray exposure (0.1, $1 \mathrm{~Gy})$ was also observed in a three-dimensional skin tissue model [71].

The different gene expression profile after ${ }^{48} \mathrm{Ti}$ ion irradiation indicates distinct responses, depending on radiation quality, eventually including different repair mechanisms, as indicated in the survival curves in this work. These genes are expressed after X-irradiation, but not after ${ }^{48} \mathrm{Ti}$ ion exposure. The missing expression of the protecting RelB gene after heavy ion exposure might be another explanation why RelA knock-down results in higher X-ray sensitivity, but not in higher heavy ion exposure sensitivity: Its protecting effect ceases to exist in HEK shRNA RelA cells after $\mathrm{X}$-irradiation, but it is not induced after heavy exposure even in case of normal RelA levels.

CD83 expression was activated by 4 Gy Ti ions, TNF- $\alpha$ and 8 Gy X-rays. It is one of the central regulatory molecules in immune functions with anti-tumor effects [72]. It acts as a co-stimulator during activation of T-cells by antigen-presenting cells and is therefore essential for the induction of the adaptive immune response. NF- $\mathrm{KB}$ regulates inducible CD83 gene expression in activated $\mathrm{T}$ lymphocytes during an adaptive immune response [73]. Increased expression of this costimulatory molecule indicates that exposure to ionizing radiation does not only induce inflammation as a prominent innate immune response via proinflammatory cytokines such as TNF- $\alpha$ and via chemokines, but also induces selected steps towards activation of adaptive immunity.

In absence of RelA, only TNFRSF1B is upregulated after X-ray exposure. TNFRSF1B encodes for the TNF receptor TNF-R2. It was shown that TNFRSF1B receptor signaling resulted in the activation of anti-apoptotic survival proteins [74]. At the same time, TNFRSF1B promotes TNF- $\alpha$ induced apoptosis [75]. Baseline plasma TNFRSF1B, a marker of inflammation and a soluble TNF antagonist, was significantly associated with an increased risk of human colorectal cancer [76]. TNF- $\alpha$ bound to TNFRSF1B recruits intracellular adaptor proteins to activate multiple signal transduction pathways including NF- $\mathrm{KB}$ [77]. The activation of NF- $\mathrm{KB}$ in intestinal epithelial cells by TNF- $\alpha$ through TNFRSF1B receptor signaling has been previously linked to carcinogenesis. Silencing TNFRSF1B increased apoptosis [74]. However, NF- $\kappa B$ interferes with apoptotic signals at various levels. The best example is found in the TNF-R1 pathway [78]. It is therefore not certain whether increased apoptosis results from pro-apoptotic TNFRSF1A signaling. An upregulation of TNFRSF1B expression $8 \mathrm{~h}$ after $\mathrm{X}$-ray exposure $(0.1,1 \mathrm{~Gy})$ was also observed in a three-dimensional skin tissue model [71]. 
Overall, results revealed the outstanding role of NF- $\mathrm{KB}$ and its subunit RelA in cytokine expression after exposure to low- and high-LET radiation and therefore in the "sterile inflammation" after radiation exposure [57]. In contrast to other studies with cancer cells, no radiation-induced upregulation of antiapoptotic genes above the threefold threshold was found. BIRC 3 encoding CIAP2 was upregulated 2.0 and 2.5 times after exposure to 4 and $8 \mathrm{~Gy}$ X-rays, respectively. In differentiated thyroid cancer (DTC) cells, incubation with (131)I-induced NF- $\mathrm{kB}$ activation, and knock-down of p65 by siRNA transfection increased (131)I-induced cell killing [79]. This effect was explained by lower expression of the antiapoptotic NF-kB target genes XIAP, cIAP1, and Bcl-xL when $\mathrm{p} 65$ expression was downregulated by siRNA [79].

\subsection{Role of RelA in IL-8 and TNF- $\alpha$ Production for Survival after Exposure to Different Radiation Qualities}

IL8 (Interleukin 8, CXCL8) was severely downregulated (-8.1) in HEK shRNA RelA cells. In presence of RelA, IL-8 secretion was strongly induced by TNF- $\alpha$ and high X-ray doses. This cytokine is part of the CXC chemokine family and acts as proinflammatory mediator, further activating proinflammatory cytokines in a positive feedback loop. It attracts and activates neutrophils [80], causing them to migrate towards the site of infection. It was shown for several cell types, that the NF- $\mathrm{KB}$ binding site is essential for transcription of IL-8 [81,82]. Interleukin 8 secretion was also increased in response to oxidative stress, mediated by TNF- $\alpha$, which further induces RelA-binding to the binding site of the IL-8 promoter [56]. In HTori-3 cells, a human thyroid epithelial cell line, exposed to either a non-toxic radiation dose $(0.1 \mathrm{~Gy})$ or a slightly toxic dose $(0.2 \mathrm{~Gy})$ from iron ions $(1 \mathrm{GeV} / \mathrm{n})$, IL-8 expression was altered [83]. In organotypic cultures of oral mucosa irradiated with X-rays or carbon ions, both radiation qualities increased the release of IL-8, with a saturation at 4 Gy for early time points, and higher early increases $(4 \mathrm{~h})$ after carbon ion exposure in the spread-out Bragg peak (SOBP, track-averaged LET $\sim 50 \mathrm{keV} / \mu \mathrm{m}$ ) $[84,85]$. The IL-8 release remained increased for two days after carbon ion exposure $(2,4,10 \mathrm{~Gy})$ [84].

TNF- $\alpha$ secretion was increased after higher doses of X-rays (16 Gy), while its mRNA level was enhanced already at a dose of $4 \mathrm{~Gy}$.

\subsection{Implications for Countermeasure Development}

Although caution should be taken to directly translate in vitro data to a clinical setting and the doses used here are quite high, the study suggests that due to NF- $\mathrm{KB}$ activation by heavy ion exposure astronauts would be prone to "sterile inflammation" in relevant target organs. Indeed, Parihar et al. found increased numbers of activated microglia in the perirhinal cortex of rodents exposed to low doses of helium and other space-relevant accelerated ions, indicating neuroinflammation [86,87].

For ensuring astronauts' health, countermeasures have to be developed which could rely not necessarily on therapeutically applied drugs but on natural inhibitors of the proteasome or other regulating factors in the NF- $\mathrm{kB}$ pathway as dietary supplements. The proteasome inhibitor MG132 which was used in this study is not such a candidate as it inhibits multiple proteases in addition to the proteasome. Furthermore, at least in tumor cells, treatment with MG-132 prior to irradiation lead to radiosensitization [88], which is an effect exploited for tumor therapy with the proteasome inhibitor bortezomib [89].

Possible candidates for protection against chronic inflammation could be members of the triterpenoid family, which inhibit the NF- KB pathway at various sites $[90,91]$. Additionally, in our earlier studies, capsaicin, an active component of the red pepper (Capsicum), partially inhibited NF- $\mathrm{KB}$ activation in HEK cells in a non-toxic concentration range [92]. However, NF- $\mathrm{kB}$ is a central element of various physiological functions and its inhibition might be associated with various side effects. Therefore, evaluation of its target genes that are upregulated by radiation exposure might lead to more specific toeholds to mitigate radiation-induced inflammation.

For high-dose exposure that could occur during a large solar particle event, activation of the NF-KB pathway might increase the survival of, e.g., bone marrow stem cells and intestinal epithelial 
cells and thereby ameliorate the acute radiation syndrome. For this purpose, Toll-like receptor 5 (TLR5) agonists were developed based on bacterial flagellin and successfully tested in animal models [93].

\subsection{Conclusions}

RelA is essential for cytokine and chemokine expression after exposure to both, low- and high-LET radiation and it thereby shapes the sterile inflammatory response, which comprises a smaller NF- $\mathrm{kB}$ target gene subset compared to TNF- $\alpha$ treatment. ATM and the proteasome are essential for NF- $\mathrm{KB}$ activation by different radiation qualities. NF- $\mathrm{kB}$ confers a survival advantage after $\mathrm{X}$-ray, but not after heavy ion exposure.

\section{Materials and Methods}

\subsection{Transformation and Preparation of Plasmid DNA}

For plasmid propagation, $100 \mu \mathrm{L}$ of competent E. coli DH5 $\alpha$-cells (Stratagene; Agilent Technologies, Karlsbrunn, Germany) were transformed with $2 \mu \mathrm{L}$ of each SureSilencing ${ }^{\mathrm{TM}}$ shRNA Plasmid ( 30-50 ng/ $\mu \mathrm{L})$ according to the manufacturer's protocol. The transformed bacteria were plated on selective LB-agar plates containing ampicillin (Biochrom $\mathrm{GmbH}$, Berlin, Germany) with a final concentration of $50 \mu \mathrm{g} / \mathrm{mL}$ for selection and incubated at $37^{\circ} \mathrm{C}$ over night. For plasmid preparation, single colonies were cultured for $16 \mathrm{~h}$ in $100 \mathrm{~mL}$ of LB-medium containing ampicillin under permanent shaking. For preparation of plasmid DNA the Plasmid Maxi Kit (Qiagen, Hilden, Germany) was used following the instructions of the manufacturer. For quality control, the optical density at $260 \mathrm{~nm}$ and $280 \mathrm{~nm}$ was determined in a spectrophotometer (Nanodrop 2000c, Thermo Scientific, Langenselbold, Germany). Only preparations with an OD260/OD280 of more than 1.8 were used for the transfection of human cells.

\subsection{Cell Culture}

The cell line HEK 293 was established by Graham et al. (1977) from human embryonic kidney cells immortalized by transfection with sheared fragments of adenovirus type 5 DNA [94]. The cells contain only the stably integrated region (E1a and E1b genes) of the human adenovirus genome and do not produce viral particles. Cells were obtained from the American Type Culture Collection (ATCC CRL-1573; now: LGC Standards, Wesel, Germany). Cloning of the plasmid pNF-kB-d2EGFP/Neo, stable transfection and selection of an appropriate cell clone (HEK-pNF-kB-d2EGFP/Neo L2) was already described [27]. HEK-pNF-kB-d2EGFP/Neo L2 and untransfected HEK cells have comparable radiosensitivity to $X$-rays and to accelerated carbon ions and show no difference in proliferation [19]. Cells were maintained in $\alpha$-medium (Biochrom KG, Berlin, Germany) containing $0.6 \mathrm{mg} / \mathrm{mL}$ G418 and $10 \%$ fetal bovine serum (FBS) at standard conditions $\left(37{ }^{\circ} \mathrm{C}, 95 \%\right.$ air and $5 \% \mathrm{CO}_{2}$ atmosphere). Cells were passaged every week and seeded in a cell density of $3 \times 10^{4}$ cells $/ \mathrm{cm}^{2}$ in $80 \mathrm{~cm}^{2}$ cell culture flasks (Nunc, Novodirect, Kehl, Germany). Medium was exchanged after four days. Cell culture vessels were coated with poly-D-lysine $\left(10 \mu \mathrm{g} / \mathrm{cm}^{2}\right.$, Sigma-Aldrich Chemie, Steinheim, Germany, in sterile deionized water) to allow a stronger binding of cells to the substrate. Therefore, the culture vessels were coated with poly-D-lysine for $15 \mathrm{~min}$ at room temperature and subsequently washed three times with sterile deionized water.

\subsection{Stable Transfection}

For knock-down of the NF-kB subunit RelA, HEK-pNF-kB-d2EGFP/Neo L2 were stably transfected with the SureSilencing ${ }^{\mathrm{TM}}$ shRNA plasmids RELA-1 to 4 and the control plasmid from SABiosciences (Frederick, MD, USA). Four of these plasmids encoded different targeting sequences of RelA mRNA, while the fifths plasmid was a negative control vector containing a scrambled artificial sequence which did not match any human, mouse or rat gene. HEK-pNF-kB-d2EGFP/Neo L2 cells were seeded in poly-D-lysine-coated 6-well-plates (Nunc). Transfection was conducted at a cell density 
of $\sim 50 \%$. Therefore, $2 \mu \mathrm{g}$ of DNA of each vector were mixed with the transfection reagent FuGENE $6^{\circledR}$ (Roche, Mannheim, Germany) and serum-free $\alpha$-medium according to the protocol. After three days of incubation, cells were transferred into $\varnothing 6 \mathrm{~cm}$ culture dishes (Nunc) containing $\alpha$-medium with $400 \mu \mathrm{g} / \mathrm{mL}$ hygromycin (US Biological, Salem, MA, USA). After approximately 10 days, cells were seeded for RNA isolation (Section 4.9.1) to measure the knock-down level of RelA in the mixed population by real-time quantitative Reverse Transcriptase Polymerase Chain Reaction (RT-qPCR). The strongest knock-down of RelA expression was achieved with the plasmids RELA-1 and RELA-4 (Figure 4A). Therefore, clones grown from single cells of these two cell populations were grown by seeding 50 cells per microtiter plate containing hygromycin-medium. Cells were incubated for 2-3 weeks until colonies were grown. A single colony was washed with PBS, trypsinized and added to a $25 \mathrm{~cm}^{2}$ cell culture flask (Nunc) containing $5 \mathrm{~mL}$ of hygromycin-medium. When cells had reached a density of $80-100 \%$, their knock-down level was determined by seeding them in triplicates and proceeding according to 4.10 . In clone 4-9, RelA mRNA expression was reduced by $83.1 \%$ and it was used for further experiments. The selected clone was named HEK shRNA RelA and is characterized by a RelA knock-down level of $83.1 \%$ and a resistance against hygromycin.

\subsection{Growth Kinetics}

To characterize differences in growth behavior between HEK-pNF-kB-d2EGFP/Neo L2 and HEK shRNA RelA, both cell lines were seeded with the same cell number $\left(1 \times 10^{4} \mathrm{cells} / \mathrm{cm}^{2}\right)$ in poly-D-lysine-coated 6-well plates. The cell number of one well was determined daily until cells reached the stationary growth phase.

\subsection{Treatment Modalities}

For cytokine treatment or irradiation experiments, $3 \times 10^{4} \mathrm{cells} / \mathrm{cm}^{2}$ were seeded into suitable culture vessels freshly coated with poly-D-lysine $\left(10 \mu \mathrm{g} / \mathrm{cm}^{2}\right.$, Sigma-Aldrich Chemie, Steinheim, Germany) for 15 min followed by washing with phosphate buffered saline (PBS). For exposure to TNF- $\alpha$, X-rays and heavy ions, cells were seeded into $25 \mathrm{~cm}^{2}$ flasks (Iwaki, Dunn Labortechnik $\mathrm{GmbH}$, Asbach, Germany for GANIL, Nunc for GSI and HIMAC). Cells were incubated for two days before treatment.

\subsubsection{Cytokine Treatment}

Human recombinant TNF- $\alpha$ was obtained from Sigma-Aldrich Chemie. TNF- $\alpha$ (final concentration $10 \mathrm{ng} / \mathrm{mL}$ ), was dissolved in PBS, and added in serum-containing medium. Cells were harvested for flow cytometry as described in 0 after different time points. Control dishes were solvent-treated.

\subsubsection{X-Irradiation}

X-irradiation was performed at DLR in Cologne using a Gulmay RS225 X-ray source (Xstrahl, Surrey, UK). Cells were irradiated at room temperature with $200 \mathrm{kV}$ and $15 \mathrm{~mA}$ at a dose rate of $\sim 1 \mathrm{~Gy} / \mathrm{min}$. To eliminate soft X-rays, a copper filter (thickness $0.5 \mathrm{~mm}$ ) was used. Cells were irradiated in petri dishes (Ø 3 or $6 \mathrm{~cm}$ ). Doses up to $16 \mathrm{~Gy}$ were used, with an LET of $0.3-3 \mathrm{keV} / \mu \mathrm{m}$. Control dishes were sham-irradiated. Doses were determined using the UNIDOS ${ }^{\text {webline }}$ (PTW, Freiburg, Germany).

\subsubsection{Heavy Ion Exposure}

Irradiation with accelerated heavy ions was performed at the "Grand Accélérateur National d'Ions Lourds" (GANIL, Caen, France), at the GSI Helmholtzzentrum für Schwerionenforschung $\mathrm{GmbH}$ (GSI) in Darmstadt, Germany, or at the Heavy Ion Medical Accelerator in Chiba (HIMAC), Japan. Characteristics of the applied beams including the LET in water are shown in Table 5. 
Table 5. Characteristics of the heavy ion beams.

\begin{tabular}{cccccc}
\hline & \multicolumn{2}{c}{ Energy $(\mathbf{M e V} / \mathbf{n})^{\mathbf{a}}$} & LET $(\mathbf{k e V} / \boldsymbol{\mu m})$ & $\begin{array}{c}\text { Penetration Depth }(\boldsymbol{\mu m}) \\
\text { Accelerator }\end{array}$ \\
\hline Ion Species & Beam & on Target $^{\mathbf{b}}$ & \multicolumn{3}{c}{${\text { in } \mathbf{H}_{\mathbf{2}} \mathbf{O}}$} \\
\hline Carbon $\left({ }^{12} \mathrm{C}\right)$ & 400.0 & 400.0 & 10.0 & 272,900 & HIMAC \\
Carbon $\left({ }^{13} \mathrm{C}\right)$ & 75.0 & 71.4 & 34.2 & 15,120 & GANIL \\
Silicon $\left({ }^{28} \mathrm{Si}\right)$ & 490.0 & 490.0 & 55.0 & 161,300 & HIMAC \\
Titanium $\left({ }^{88} \mathrm{Ti}\right)$ & 1000.0 & 996.9 & 107.7 & 319,900 & GSI \\
Nickel $\left({ }^{58} \mathrm{Ni}\right)$ & 1000.0 & 996.9 & 174.5 & 263,600 & GSI \\
Argon $\left({ }^{36} \mathrm{Ar}\right)$ & 95.0 & 83.8 & 271.5 & 6336 & GANIL \\
\hline
\end{tabular}

${ }^{a}$ Mega-electron-Volt/nucleon. ${ }^{b}$ Effective irradiation energy at the cell monolayer. For GANIL beam times energy losses occur in two detectors, the exit window, $\sim 1 \mathrm{~cm}$ air and the bottom of the culture vessel $(1200 \mu \mathrm{m}$ polystyrene or $25 \mu \mathrm{m}$ polytetrafluoroethylene foil). For GSI and HIMAC beams energy losses are marginal (only from bottom of the culture vessel).

Adherent cells were irradiated in sub-confluent stage and in upright position at room temperature. Therefore, flasks and petri dishes were completely filled with $\alpha$-medium and closed. Dosimetry was performed by the staff at the accelerator facilities. Dose rates were adjusted to approximately $1 \mathrm{~Gy} / \mathrm{min}$. At GANIL, dosimetry was performed by the "Centre de recherches sur les Ions, les Matériaux et la Photonique" (CIMAP)/"Laboratoire d'Accueil en Radiobiologie avec les Ions Accélérés" (LARIA) staff, yielding the fluence in particles $/ \mathrm{cm}^{2}\left(\mathrm{P} / \mathrm{cm}^{2}\right)$ [95]. To convert fluence $(\mathrm{F})$ to the energy dose, the following formula was applied [96]:

$$
\text { Dose[Gy] }=1.6 \times 10^{-9} \times \mathrm{LET}[\mathrm{keV} / \mu \mathrm{m}] \times \mathrm{F}\left[\mathrm{P} / \mathrm{cm}^{2}\right]
$$

After irradiation, serum-free $\alpha$-medium was discarded and cells were further cultivated with fresh medium containing $10 \%$ FBS.

\subsection{Cytotoxicity of Chemical Inhibitors}

Cytotoxicity of chemical inhibitors KU-55933 and MG-132 was measured by the MTT assay. Reduction of MTT (3-(4,5-dimethylthiazole-2-yl)-2,5-diphenyltetrazolium bromide) to formazan is correlated to the activity of cellular enzymes and measured colorimetrically. HEK-pNF-kB-d2EGFP/Neo L2 cells were seeded in 96-well plates and incubated with each inhibitor for 20 and 72 hours. NF- $\mathrm{kB}$ was activated by adding TNF- $\alpha$ protected from light. 100\% DMSO was added to one well to measure the background signal. After removing medium, cells were incubated for $1 \mathrm{~h}$ at $37{ }^{\circ} \mathrm{C}$ with serum-free $\alpha$-medium containing $0.1 \mathrm{mg} / \mathrm{mL}$ MTT. Subsequently, cells were lysed with DMSO with $10 \%(w / v)$ sodium dodecyl sulfate (SDS) and $0.6 \%(v / v)$ acetic acid while shaking them for $20 \mathrm{~min}$ with $30 \mathrm{rpm}$. Finally, absorbance of formazan was measured with the fluorescence/luminescence microplate reader Lambda Fluoro 320 (MWG Biotech AG, Penzberg, Germany) at $562 \mathrm{~nm}$. Cell survival was calculated as a ratio of formazan-absorbance of treated vs. untreated samples after subtraction of the background signal.

\subsection{Colony Forming Ability}

For investigating cellular survival after exposure to X-rays and heavy ions, cells were seeded and irradiated as already described. Immediately after irradiation adherent cells were trypsinized and re-plated in six petri dishes per dose. The cell density for seeding of irradiated cells was adjusted to compensate for the plating efficiency of the respective cell line and for the anticipated lethal effect of the treatment in order to allow growth of 40-60 colonies per dish.

After 21 days of incubation without medium change the resulting colonies were fixated and stained ( $1 \mathrm{mg} / \mathrm{mL}$ crystal violet in 3\% formaldehyde solution, Sigma-Aldrich Chemie) and colonies containing more than 50 cells were counted. The experiments were performed with six dishes per dose and repeated if beam time was available. 
All data from the irradiated samples were fitted by least-squares linear regression analysis to $\ln S=\ln \left(\mathrm{PE}_{\mathrm{D}} / \mathrm{PE} \mathrm{D}=0_{0}\right)$ versus dose, where the natural logarithm of $\mathrm{S}$ is the survival and $\mathrm{PE}$ are the plating efficiencies of treated $\left(\mathrm{PE}_{\mathrm{D}}\right)$ or untreated cells $(\mathrm{PE}=0)$. Differences in the survival curves were statistically verified by a two-sided Student's $t$-test of the regression lines. A $p$ level of 0.05 was considered to reflect significance.

\subsection{Flow Cytometry}

For measurement of d2EGFP, cells were harvested at different time points after radiation or cytokine treatment by trypsinization and fixed with $4.5 \mathrm{~mL}$ cold $3.5 \%$ formaldehyde in PBS. For flow cytometric analysis, cells were centrifuged and resuspended in PBS. Forward and side scatter and green fluorescence (FL-1) of 20,000 cells from the samples were measured in a FACScan (Becton Dickinson, San Jose, CA, USA) with an argon laser $(488 \mathrm{~nm})$ as excitation source. The markers d2EGFP ${ }^{(-)}$and $\mathrm{d} 2 \mathrm{EGFP}^{(+)}$were set by means of untreated and TNF- $\alpha$ treated cells. The percentage of d2EGFP ${ }^{(+)}$cells was used as measure of NF-kB-dependent d2EGFP expression.

\subsection{Gene Expression Analysis}

\subsubsection{RNA Isolation}

Each sample was seeded in triplicates. At a density of $\sim 50 \%$ cells were lysed with RLT buffer containing 1\% $14.3 \mathrm{~mol} / \mathrm{L} \beta$-mercaptoethanol and transferred into an RNase-free Eppendorf tube with an iced syringe. RNA was isolated using the RNeasy ${ }^{\circledR}$ Mini Kit (Qiagen, Hilden, Germany) according to the manufacturer's protocol. As RNA was used for cDNA synthesis and subsequent RT-qPCR, the additional DNase treatment step was included to eliminate residual genomic DNA. RNA was eluted in $50 \mu \mathrm{L}$ RNase-free $\mathrm{H}_{2} \mathrm{O}$.

RNA concentration and purity were measured photometric (A260/280) with the NanoDrop 2000c Spectrometer (Thermo Scientific, Waltham, MA, USA). Additionally, RNA concentration, RNA integrity (RNA Integrity Number; RIN) and rRNA ratio (28S/18S) were measured by micro-electrophoresis using the RNA 6000 Nano Assay in the Agilent 2100 Bioanalyser (Agilent Technologies, Santa Clara, CA, USA).

For gene expression analysis with the RT2 Profiler ${ }^{\mathrm{TM}}$ PCR Arrays (SABiosciences, Washington, DC, USA), further RNA quality control with RT2 RNA QC PCR array (SABiosciences) was performed.

\subsection{2. cDNA Synthesis}

Quality, integrity and quantity of isolated RNA were analyzed. Subsequently, RNA was transcribed into cDNA using the RT2 First Strand Kit (SABiosciences). A preliminary genomic DNA elimination step was conducted by incubation of $1 \mu \mathrm{g}$ total RNA with gDNA Elimination Buffer, as recommended in the protocol. To detect possible remaining genomic DNA contamination in isolated RNA samples, one sample lacking reverse transcriptase was used as a negative control. The reaction mix (4 $\mu \mathrm{L}$ BC 3 (5X RT Buffer), $2 \mu \mathrm{L}$ PC2 (Primer and External Control Mix 3), $2 \mu \mathrm{L}$ RE3 (RT Enzyme

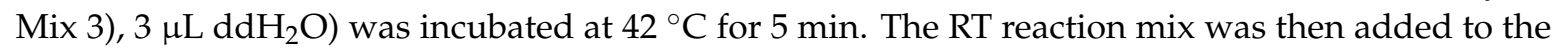
Genomic DNA Elimination Mixture and incubated at $42{ }^{\circ} \mathrm{C}$ for $15 \mathrm{~min}$. The reaction was stopped by heating at $95{ }^{\circ} \mathrm{C}$ for $5 \mathrm{~min}$. cDNA concentration at this stage was $50 \mathrm{ng} / \mu \mathrm{L}$. Finally, $91 \mu \mathrm{L}$ of $\mathrm{H}_{2} \mathrm{O}$ were added to each $20 \mu \mathrm{L}$ cDNA synthesis reaction to obtain a final cDNA concentration of $9 \mathrm{ng} / \mu \mathrm{L}$. cDNA samples were stored at $-20^{\circ} \mathrm{C}$.

\subsubsection{Setting Up RT-qPCR Validation of Knock-Down-Level}

The quantitative real-time PCR reaction mix for one PCR tube was composed referring to the RT2 qPCR Primer Assays protocol (SABiosciences) as follows: $12.5 \mu \mathrm{L}$ RT2 SYBR Green qPCR Master Mix, $8.5 \mu \mathrm{L} \mathrm{ddH} \mathrm{H}_{2} \mathrm{O}, 3 \mu \mathrm{L}$ Template cDNA $(27 \mathrm{ng})$ and $1 \mu \mathrm{L} 10 \mu \mathrm{mol} / \mathrm{L}$ PCR primer pair stock. 
As a negative control DNA was replaced by $\mathrm{H}_{2} \mathrm{O}$. The primer pairs $S Y B{ }^{\circledR}$ Green Human RELA and SYBR ${ }^{\circledR}$ Green Human HPRT 1 (RT2 qPCR Primer Assay, SABiosciences) were used for targeting the gene of interest (GOI) RelA and the housekeeping gene (HKG) HPRT (Table 6).

Table 6. RT-qPCR primer pairs * as described in the RT2 qPCR Primer Assay (SABiosciences).

\begin{tabular}{cccc}
\hline Gene Symbol & REF SEQ ACC. \# & Amplicon Size & Melting Temperature \\
\hline RELA & NM_021975.3 & $65 \mathrm{bp}$ & $80.0^{\circ} \mathrm{C}$ \\
HPRT1 & NM_000194.2 & $89 \mathrm{bp}$ & $76.5^{\circ} \mathrm{C}$ \\
\hline
\end{tabular}

* All genes listed are human genes. HPRT, Hypoxanthine phosphoribosyltransferase 1; RELA, V-rel reticuloendotheliosis viral oncogene homolog A (avian).

\subsubsection{Human RT2 Profiler PCR Array}

RT2 Profiler ${ }^{\text {TM }}$ PCR Arrays (SABiosciences) were used to profile the expression of 88 genes per sample. Two different arrays were available, with one being customized (PAHS-021), individually composed of genes of interest of several signaling pathways (Human Cell Cycle, PAHS-020A; Human NF-kB Signaling Pathway, PAHS-025A; Human p53 Signaling Pathway, PAHS-027A; Human Apoptosis, PAHS-012A; Human PI3K-AKT Signaling Pathway, PAHS-058A; Human Stress and Toxicity Pathway Finder, PAHS-003A; Human DNA Damage Signaling Pathway, PAHS-029A; Human Oxidative Stress and Antioxidant Defense, PAHS-065A) for an initial screening (Table A2) and one array focusing on genes targeted by NF- $\mathrm{kB}$ (human NF- $\mathrm{kB}$ target gene array, PAHS-225ZD, Table A1). An overview of all genes included in these arrays is listed in Appendix A. Overall, 162 genes, involved in cell cycle control, apoptosis, DNA damage, stress and toxicity and NF- $\mathrm{kB}$ signaling were investigated. Each well of these arrays contains primers for the respective gene.

Only cDNA samples, which had been approved by the RT2 RNA QC PCR Array (SA Biosciences) to prevent false positive signals by genomic DNA contamination, were used for further analysis. The RT-qPCR master mix for one 96-well plate was set up according to the RT2 RNA QC PCR Array protocol using $1350 \mu \mathrm{L}$ RT2 SYBR Green qPCR Master Mix, $1248 \mu \mathrm{L}$ ddH $_{2} \mathrm{O}$ and $102 \mu \mathrm{L}$ template cDNA $(9 \mathrm{ng} / \mu \mathrm{L})$.

Quantitative real-time analysis was performed in the Opticon2 thermocycler starting with an initial denaturation for $10 \mathrm{~min}$ at $95^{\circ} \mathrm{C}$, following by 40 cycles (denaturation for $15 \mathrm{~s}$ at $95^{\circ} \mathrm{C}$, annealing for $35 \mathrm{~s}$ at $55^{\circ} \mathrm{C}$, elongation for $30 \mathrm{~s}$ at $72{ }^{\circ} \mathrm{C}$, plate read), a final incubation for $1 \mathrm{~min}$ at $95^{\circ} \mathrm{C}$ and 2 min at $65^{\circ} \mathrm{C}$, and a melting curve from $65-95^{\circ} \mathrm{C}$ with reads every $0.2^{\circ} \mathrm{C}$. The threshold cycle $(\mathrm{Ct})$ was determined in the amplification plots. Results were analyzed according to the algorithm described in the RT2 RNA QC PCR Array protocol. It is based on the $\Delta \Delta C$ method:

$$
\begin{gathered}
\Delta \mathrm{Ct}=\mathrm{Ct} \text { (target gene) }-\mathrm{Ct} \text { (reference gene) } \\
\Delta \Delta \mathrm{Ct}=\Delta \mathrm{Ct}(\text { sample })-\Delta \mathrm{Ct}(\text { control })
\end{gathered}
$$

The relative expression of treated sample versus control was calculated by means of Equation (4):

$$
\text { Rate of gene expression }=2^{-\Delta \Delta C t}
$$

In a cautious data interpretation, the threshold for significant up- or downregulation was set to -3 or +3 , respectively, to avoid misinterpretation of physiological fluctuation of mRNA levels.

\subsection{Measurement of Cytokine Secretion}

To measure the cytokine concentration in the cell culture supernatants $(100 \mu \mathrm{L}$ aliquots, frozen and stored at $-80^{\circ} \mathrm{C}$ after collection and once thawed, centrifuged for $5 \mathrm{~min}$ at a relative centrifugal field of $300 \times g$ ) of HEK-pNF-kB-d2EGFP/Neo L2 and HEK shRNA RelA cells, the LUNARISTM Human 11-Plex Cytokine Kit was used (LHCY-20110S, Ayoxxa Biosystems GmbH, Köln, Germany) 
which is based on beads-on-a-chip technology with a classical sandwich immunoassay principle and a fluorescence readout. The calibration curve was generated according to the kit handbook. Briefly, seven standards were prepared by serial dilution (1:4) of the Human Cytokine Standard using Assay Diluent 2. The standard contained the following analytes: GM-CSF, IFN- $\gamma$, IL-1 $\beta$, IL-2, IL-4, IL-5, IL-6, IL-8, IL-10, IL-12(p70) and TNF- $\alpha$. The LUNARIS ${ }^{\mathrm{TM}}$ BioChips were first washed and the $5 \mu \mathrm{L}$ of standard, blank and samples which were diluted 1:2 in Assay Diluent 2 were loaded into the appropriate wells. After an incubation of at least $3 \mathrm{~h}$ at room temperature, the BioChips were washed and $10 \mu \mathrm{L}$ of detection antibody solition was added and allowed to incubate for $60 \mathrm{~min}$ at RT. The BioChips were washed again and then $10 \mu \mathrm{L}$ of Streptavidin-Phycoerythrin (SA-PE) reagent was added. After $30 \mathrm{~min}$ of incubation, the final washing step was performed and the BioChips were air-dried and imaged using the LUNARIS ${ }^{\mathrm{TM}}$ Reader (LRS-001). The quantification of the readout was performed using the LUNARIS $^{\mathrm{TM}}$ Analysis Suite Software.

\subsection{Statistics}

Each experiment was repeated up to five times depending on the availability of beam time with one to six replicates each. In order to account for different numbers of replicates and repeats, the standard error was calculated. Means, standard errors and significance levels in the t-test were calculated with Microsoft ${ }^{\circledR}$ Office Excel 2010 (Microsoft Deutschland GmbH, München, Germany). Regression analyses were performed using SigmaPlot 13.0.

Author Contributions: Conceptualization, C.E.H., K.K. and C.B.-K.; Data curation, C.E.H., L.F.S., K.K., S.F. and C.B.-K.; Formal analysis, C.E.H., K.K., C.S. and C.B.-K.; Funding acquisition, C.E.H. and C.B.-K.; Investigation, C.E.H., L.F.S., K.K., A.A.C., B.H., S.D., B.K., S.F., C.S., T.B. and C.B.-K.; Methodology, C.E.H. and K.K.; Project administration, C.E.H. and C.B.-K.; Resources, C.E.H. and C.B.-K.; Supervision, C.E.H. and C.B.-K.; Visualization, C.E.H., L.F.S., K.K., S.F. and C.B.-K.; Writing-original draft, C.E.H. and K.K.; Writing-review and editing, C.B.-K. All authors have approved the submitted version and agree to be personally accountable for the author's own contributions and for ensuring that questions related to the accuracy or integrity of any part of the work, even ones in which the author was not personally involved, are appropriately investigated, resolved, and documented in the literature.

Funding: The project was supported by the DLR grant FuE-Projekt "ISS LIFE" (programm RF-FuW, Teilprogramm 475). The Helmholtz Association and the German Aerospace Center are acknowledged for funding doctoral students of the Helmholtz Space Life Sciences Research School (SpaceLife, grant VH-KO-300) involved in the accelerator experiments. The travel costs to the GANIL were supported in part by the European Union (EURONS). The travel costs to the HIMAC were supported in part by the International Open Laboratory of the National Institute of Radiation Science (NIRS) and National Institutes for Quantum and Radiological Science and Technology (QST), Anagawa, Inageku, in Chiba, Japan.

Acknowledgments: We thank Isabelle Testard, Amine Cassimi, Florent Durantel, Hermann Rothard and all the physicists of CIMAP (Caen, France) involved in dosimetry and the beam operator team at GANIL for providing us valuable advice and many help given during numerous night shifts at the French Heavy Ion Accelerator GANIL. Michael Scholz, Chiara La Tessa and the beam operators are acknowledged for their valuable help during beam times GSI. The authors would like to thank Teruaki Konishi from NIRS and QST, Anagawa, Inageku, in Chiba, Japan, for the support during HIMAC beamtimes.

Conflicts of Interest: The authors declare no conflicts of interest. 


\section{Abbreviations}

\begin{tabular}{|c|c|}
\hline AP-1 & activated protein 1 \\
\hline ATCC & American Type Culture Collection \\
\hline CIMAP & Centre de recherches sur les Ions, les Matériaux et la Photonique \\
\hline d2EGFP & destabilized EGFP \\
\hline DDR & DNA damage response \\
\hline DNA-PK & DNA-dependent protein kinase \\
\hline DSB & double strand break \\
\hline EGFP & Enhanced Green Fluorescent Protein \\
\hline ESCC & esophageal squamous cell cancer \\
\hline EXO1 & exonuclease 1 \\
\hline FBS & fetal bovine serum \\
\hline GANIL & "Grand Accélérateur National d'Ions Lourds" \\
\hline GSI & GSI Helmholtzzentrum für Schwerionenforschung GmbH \\
\hline HEK & human embryonic kidney \\
\hline HIMAC & Heavy Ion Medical Accelerator in Chiba \\
\hline HR & Homologous Recombination \\
\hline HSPC & hematopoietic stem and progenitor cells \\
\hline IAP & inhibitor of apoptosis protein \\
\hline $\mathrm{I} \kappa \mathrm{B} \alpha$ & inhibitor of NF-kB $\alpha$ \\
\hline IKK & IкB kinase \\
\hline IKB $\alpha-S R$ & super-repressor variant of IкB $\alpha$ \\
\hline ISS & International Space Station \\
\hline k.d. & knock-down \\
\hline LARIA & "Laboratoire d'Accueil en Radiobiologie avec les Ions Accélérés" \\
\hline LET & linear energy transfer \\
\hline MDR1 & multi-drug resistance \\
\hline $\mathrm{MeV} / \mathrm{n}$ & Mega electron Volt per nucleon \\
\hline MnSOD & manganese superoxide dismutase \\
\hline mRNA & messenger RNA \\
\hline NF- $\mathrm{kB}$ & Nuclear factor $\kappa B$ \\
\hline NHEJ & Non-Homologous Endjoining \\
\hline NPCs & neural progenitor cells \\
\hline NRE & NF- $\kappa B$ response element \\
\hline NSCs & neural stem cells \\
\hline $\mathrm{P}$ & probability \\
\hline PBL & peripheral blood lymphocytes \\
\hline PBS & phosphate buffered saline \\
\hline PI3K & phosphatidyl inositol kinase 3 \\
\hline RBE & relative biologic effectiveness \\
\hline Rel & Reticuloendotheliosis \\
\hline RT-qPCR & Reverse Transcriptase real-time quantitative PCR \\
\hline shRNA RelA & RelA short-hairpin RNA \\
\hline SD & standard deviation \\
\hline SE & standard error \\
\hline TK & thymidine kinase \\
\hline TLR5 & Toll-like receptor 5 \\
\hline TNF- $\alpha$ & tumor necrosis factor $\alpha$ \\
\hline TP53 & tumor protein p53 \\
\hline
\end{tabular}




\section{Appendix}

Table A1. Gene list of QPCR Array PAHS-225ZD.

\begin{tabular}{|c|c|c|c|c|}
\hline UniGene & GeneBank & Symbol & Description & Gene Names \\
\hline Hs. 441047 & NM_001124 & $A D M$ & Adrenomedullin & $A M$ \\
\hline Hs.19383 & NM_000029 & $A G T$ & Angiotensinogen (serpin peptidase inhibitor, clade A, member 8) & ANHU, FLJ92595, FLJ97926, SERPINA8 \\
\hline Hs. 525622 & NM_005163 & AKT1 & V-akt murine thymoma viral oncogene homolog 1 & AKT, MGC99656, PKB, PKB-ALPHA, PRKBA, RAC, RAC-ALPHA \\
\hline Hs.499886 & NM_000382 & $A L D H 3 A 2$ & Aldehyde dehydrogenase 3 family, member A2 & ALDH10, DKFZp686E23276, FALDH, FLJ20851, SLS \\
\hline Hs.227817 & NM_004049 & $B C L 2 A 1$ & BCL2-related protein A1 & ACC-1, ACC-2, BCL2L5, BFL1, GRS, HBPA1 \\
\hline Hs.516966 & NM_138578 & $B C L 2 L 1$ & BCL2-like 1 & $\begin{array}{l}B C L-X L, S, B C L 2 L, B C L X, B C L X L, B C L X S, B c l-X, D K F Z p 781 P 2092, \\
b c l-x L, b c l-x S\end{array}$ \\
\hline Hs.696238 & NM_001166 & BIRC2 & Baculoviral IAP repeat containing 2 & API1, HIAP2, Hiap-2, MIHB, RNF48, c-IAP1, cIAP1 \\
\hline Hs.127799 & NM_001165 & BIRC3 & Baculoviral IAP repeat containing 3 & AIP1, API2, CIAP2, HAIP1, HIAP1, MALT2, MIHC, RNF49, c-IAP2 \\
\hline Hs.529053 & NM_000064 & $\mathrm{C3}$ & Complement component 3 & AHUS5, ARMD9, ASP, CPAMD1 \\
\hline Hs. 54460 & NM_002986 & CCL11 & Chemokine (C-C motif) ligand 11 & MGC22554, SCYA11 \\
\hline Hs.303649 & NM_002982 & CCL2 & Chemokine (C-C motif) ligand 2 & $\begin{array}{l}\text { GDCF-2, HC11, HSMCR30, MCAF, MCP-1, MCP1, MGC9434, } \\
\text { SCYA2, SMC-CF }\end{array}$ \\
\hline Hs. 534347 & NM_002990 & CCL22 & Chemokine (C-C motif) ligand 22 & $A B C D-1, D C, B-C K, M D C, M G C 34554, S C Y A 22, S T C P-1$ \\
\hline Hs.514821 & NM_002985 & CCL5 & Chemokine (C-C motif) ligand 5 & D17S136E, MGC17164, RANTES, SCYA5, SISd, TCP228 \\
\hline Hs.450802 & NM_000579 & CCR5 & Chemokine (C-C motif) receptor 5 & $\begin{array}{l}\text { CC-CKR-5, CCCKR5, CD195, CKR-5, CKR5, CMKBR5, FLJ78003, } \\
\text { IDDM22 }\end{array}$ \\
\hline Hs. 472860 & NM_001250 & $\mathrm{CD} 40$ & CD40 molecule, TNF receptor superfamily member 5 & Bp50, CDW40, MGC9013, TNFRSF5, p50 \\
\hline Hs.208854 & NM_001781 & CD69 & CD69 molecule & CLEC2C \\
\hline Hs. 838 & NM_005191 & CD80 & CD80 molecule & B7, B7-1, B7.1, BB1, CD28LG, CD28LG1, LAB7 \\
\hline Hs.595133 & NM_004233 & CD83 & CD83 molecule & BL11, HB15 \\
\hline Hs.370771 & NM_000389 & CDKN1A & Cyclin-dependent kinase inhibitor 1A (p21, Cip1) & CAP20, CDKN1, CIP1, MDA-6, P21, SDI1, WAF1, p21CIP1 \\
\hline Hs.69771 & NM_001710 & $C F B$ & Complement factor B & AHUS4, BF, BFD, CFAB, FB, FBI12, FLJ54899, GBG, H2-Bf, PBF2 \\
\hline Hs.591402 & NM_000757 & CSF1 & Colony stimulating factor 1 (macrophage) & MCSF, MGC31930 \\
\hline
\end{tabular}


Table A1. Cont.

\begin{tabular}{|c|c|c|c|c|}
\hline UniGene & GeneBank & Symbol & Description & Gene Names \\
\hline Hs.1349 & NM_000758 & CSF2 & Colony stimulating factor 2 (granulocyte-macrophage) & GMCSF, MGC131935, MGC138897 \\
\hline Hs.592192 & NM_000395 & $C S F 2 R B$ & $\begin{array}{l}\text { Colony stimulating factor } 2 \text { receptor, beta, low-affinity } \\
\text { (granulocyte-macrophage) }\end{array}$ & CD131, CDw131, IL3RB, IL5RB \\
\hline Hs.2233 & NM_000759 & CSF3 & Colony stimulating factor 3 (granulocyte) & C17orf33, CSF3OS, GCSF, MGC45931 \\
\hline Hs.789 & NM_001511 & CXCL1 & $\begin{array}{l}\text { Chemokine (C-X-C motif) ligand } 1 \text { (melanoma growth } \\
\text { stimulating activity, alpha) }\end{array}$ & FSP, GRO1, GROa, MGSA, MGSA-a, NAP-3, SCYB1 \\
\hline Hs.632586 & NM_001565 & CXCL10 & Chemokine (C-X-C motif) ligand 10 & C7, IFI10, INP10, IP-10, SCYB10, crg-2, gIP-10, mob-1 \\
\hline Hs.77367 & NM_002416 & CXCL9 & Chemokine (C-X-C motif) ligand 9 & CMK, Humig, MIG, SCYB9, crg-10 \\
\hline Hs.488293 & NM_005228 & EGFR & Epidermal growth factor receptor & ERBB, ERBB1, HER1, PIG61, mENA \\
\hline Hs.1395 & NM_000399 & EGR2 & Early growth response 2 & AT591, CMT1D, CMT4E, DKFZp686J1957, FLJ14547, KROX20 \\
\hline Hs.62192 & NM_001993 & F3 & Coagulation factor III (thromboplastin, tissue factor) & CD142, FLJ17960, TF, TFA \\
\hline Hs.654450 & NM_000132 & F8 & Coagulation factor VIII, procoagulant component & AHF, DXS1253E, F8B, F8C, FVIII, HEMA \\
\hline Hs.244139 & NM_000043 & FAS & Fas (TNF receptor superfamily, member 6) & ALPS1A, APO-1, APT1, CD95, FAS1, FASTM, TNFRSF6 \\
\hline Hs.2007 & NM_000639 & FASLG & Fas ligand (TNF superfamily, member 6) & APT1LG1, CD178, CD95-L, CD95L, FASL, TNFSF6 \\
\hline Hs.643447 & NM_000201 & ICAM1 & Intercellular adhesion molecule 1 & $B B 2, C D 54, P 3.58$ \\
\hline Hs.93177 & NM_002176 & IFNB1 & Interferon, beta 1 , fibroblast & IFB, IFF, IFNB, MGC96956 \\
\hline Hs.856 & NM_000619 & IFNG & Interferon, gamma & IFG, IFI \\
\hline Hs. 674 & NM_002187 & IL12B & $\begin{array}{l}\text { Interleukin 12B (natural killer cell stimulatory factor 2, cytotoxic } \\
\text { lymphocyte maturation factor } 2, \mathrm{p} 40 \text { ) }\end{array}$ & CLMF, CLMF2, IL-12B, NKSF, NKSF2 \\
\hline Hs.654378 & NM_000585 & IL15 & Interleukin 15 & IL-15, MGC9721 \\
\hline Hs.1722 & NM_000575 & IL1A & Interleukin 1, alpha & IL-1A, IL1, IL1-ALPHA, IL1F1 \\
\hline Hs.126256 & NM_000576 & IL1B & Interleukin 1, beta & IL-1, IL1-BETA, IL1F2 \\
\hline Hs.25333 & NM_004633 & IL1R2 & Interleukin 1 receptor, type II & CD121b, IL1RB, MGC47725 \\
\hline Hs.81134 & NM_000577 & IL1RN & Interleukin 1 receptor antagonist & $\begin{array}{l}\text { DIRA, ICIL-1RA, IL-1RN, IL-1ra, IL-1ra3, IL1F3, IL1RA, IRAP, } \\
\text { MGC10430, MVCD4 }\end{array}$ \\
\hline Hs.89679 & NM_000586 & IL2 & Interleukin 2 & IL-2, TCGF, lymphokine \\
\hline Hs. 231367 & NM_000417 & $I L 2 R A$ & Interleukin 2 receptor, alpha & CD25, IDDM10, IL2R, TCGFR \\
\hline
\end{tabular}


Table A1. Cont.

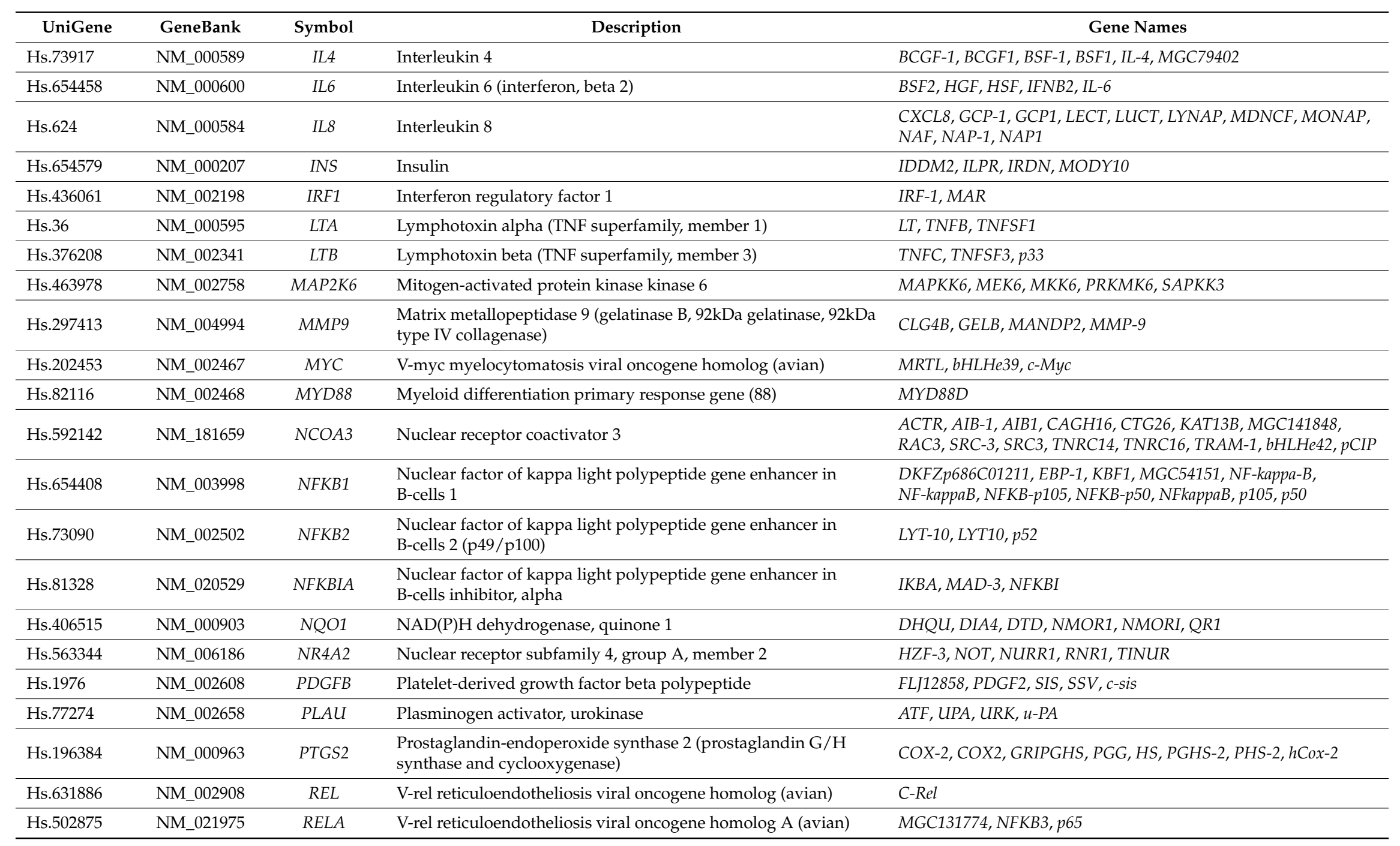


Table A1. Cont.

\begin{tabular}{|c|c|c|c|c|}
\hline UniGene & GeneBank & Symbol & Description & Gene Names \\
\hline Hs.642990 & NM_007315 & STAT1 & Signal transducer and activator of transcription $1,91 \mathrm{kDa}$ & DKFZp686B04100, ISGF-3, STAT91 \\
\hline Hs.654402 & NM_006509 & RELB & V-rel reticuloendotheliosis viral oncogene homolog B & I-REL, IREL, REL-B \\
\hline Hs. 89546 & NM_000450 & SELE & Selectin E & CD62E, ELAM, ELAM1, ESEL, LECAM2 \\
\hline Hs.73800 & NM_003005 & SELP & Selectin P (granule membrane protein 140kDa, antigen CD62) & $\begin{array}{l}\text { CD62, CD62P, FLJ45155, GMP140, GRMP, LECAM3, PADGEM, } \\
\text { PSEL }\end{array}$ \\
\hline Hs.167317 & NM_003081 & SNAP25 & Synaptosomal-associated protein, $25 \mathrm{kDa}$ & $\begin{array}{l}\text { FLJ23079, RIC-4, RIC4, SEC9, SNAP, SNAP-25, bA416N4.2, } \\
\text { dJ1068F16.2 }\end{array}$ \\
\hline Hs.463059 & NM_003150 & STAT3 & $\begin{array}{l}\text { Signal transducer and activator of transcription } 3 \text { (acute-phase } \\
\text { response factor) }\end{array}$ & APRF, FLJ20882, HIES, MGC16063 \\
\hline Hs.595276 & NM_012448 & STAT5B & Signal transducer and activator of transcription $5 \mathrm{~B}$ & STAT5 \\
\hline Hs. 241570 & NM_000594 & $T N F$ & Tumor necrosis factor & DIF, TNF-alpha, TNFA, TNFSF2 \\
\hline Hs. 256278 & NM_001066 & TNFRSF1B & Tumor necrosis factor receptor superfamily, member 1B & $\begin{array}{l}\text { CD120b, TBPII, TNF-R-II, TNF-R75, TNFBR, TNFR1B, TNFR2, } \\
\text { TNFR80, p75, p75TNFR }\end{array}$ \\
\hline Hs.478275 & NM_003810 & TNFSF10 & Tumor necrosis factor (ligand) superfamily, member 10 & APO2L, Apo-2L, CD253, TL2, TRAIL \\
\hline Hs.522506 & NM_021138 & TRAF2 & TNF receptor-associated factor 2 & MGC:45012, TRAP, TRAP3 \\
\hline Hs.109225 & NM_001078 & VCAM1 & Vascular cell adhesion molecule 1 & CD106, DKFZp779G2333, INCAM-100, MGC99561 \\
\hline Hs.356076 & NM_001167 & XIAP & X-linked inhibitor of apoptosis & API3, BIRC4, FLJ26913, IAP-3, ILP1, MIHA, XLP2, hIAP-3, hIAP3 \\
\hline Hs.520640 & NM_001101 & $A C T B$ & Actin, beta & PS1TP5BP1 \\
\hline Hs.534255 & NM_004048 & $B 2 M$ & Beta-2-microglobulin & - \\
\hline Hs.592355 & NM_002046 & GAPDH & Glyceraldehyde-3-phosphate dehydrogenase & G3PD, GAPD, MGC88685 \\
\hline Hs.412707 & NM_000194 & HPRT1 & Hypoxanthine phosphoribosyltransferase 1 & HGPRT, HPRT \\
\hline Hs.546285 & NM_001002 & RPLPO & Ribosomal protein, large, P0 & L10E, LP0, MGC111226, MGC88175, P0, PRLP0, RPP0 \\
\hline $\mathrm{N} / \mathrm{A}$ & SA_00105 & $H G D C$ & Human Genomic DNA Contamination & HIGX1A \\
\hline
\end{tabular}


Table A2. List Additional Genes of the Customized QPCR Array.

\begin{tabular}{|c|c|c|c|c|}
\hline UniGene & GeneBank & Symbol & Description & Gene Names \\
\hline Hs.131431 & NM_002759 & EIF2AK2 & Eukaryotic translation initiation factor 2-alpha kinase 2 & EIF2AK1/PKR \\
\hline Hs.141125 & NM_004346 & CASP3 & Caspase 3, apoptosis-related cysteine peptidase & СРP32/CРP32B \\
\hline Hs.146806 & NM 003592 & CUL1 & Cullin 1 & MGC149834 \\
\hline Hs.147433 & NM_182649 & PCNA & Proliferating cell nuclear antigen & MGC8367 \\
\hline Hs.160953 & NM_022112 & P53AIP1 & P53-regulated apoptosis-inducing protein 1 & P53AIP1 \\
\hline Hs. 1770 & NM_000234 & LIG1 & Ligase I, DNA, ATP-dependent & MGC117397 \\
\hline Hs.191334 & NM_003362 & UNG & Uracil-DNA glycosylase & DGU/DKFZp781L1143 \\
\hline Hs.191356 & NM_001515 & GTF2H2 & General transcription factor IIH, polypeptide 2, $44 \mathrm{kDa}$ & BTF2/BTF2P44 \\
\hline Hs.193717 & NM_000572 & IL10 & Interleukin 10 & CSIF/IL-10 \\
\hline Hs.194143 & NM_007294 & $B R C A 1$ & Breast cancer 1 , early onset & $B R C A I / B R C C 1$ \\
\hline Hs. 2420 & NM_003102 & SOD3 & Superoxide dismutase 3 , extracellular & EC-SOD \\
\hline Hs. 244723 & NM_001238 & CCNE1 & Cyclin E1 & CCNE \\
\hline Hs.24529 & NM_001274 & CHEK1 & CHK1 checkpoint homolog (S. pombe) & CHK1 \\
\hline Hs. 271791 & NM 001184 & ATR & Ataxia telangiectasia and Rad 3 related & FRP1/MEC1 \\
\hline Hs.290758 & NM_001923 & DDB1 & Damage-specific DNA binding protein 1, $127 \mathrm{kDa}$ & $D D B A / U V-D D B 1$ \\
\hline Hs.291363 & NM_007194 & CHEK2 & CHK2 checkpoint homolog (S. pombe) & CDS1/CHK2 \\
\hline Hs.31210 & NM_005178 & $B C L 3$ & B-cell CLL/lymphoma 3 & BCL4/D19S37 \\
\hline Hs.321045 & NM_014002 & IKBKE & Inhibitor of kappa light polypeptide gene enhancer in B-cells, kinase epsilon & $I K K-i / I K K E$ \\
\hline Hs.326035 & NM_001964 & EGR1 & Early growth response 1 & AT225/G0S30 \\
\hline Hs.329502 & NM_001229 & CASP9 & Caspase 9, apoptosis-related cysteine peptidase & APAF-3/APAF3 \\
\hline Hs.334562 & NM_001786 & $C D C 2$ & Cell division cycle $2, \mathrm{G} 1$ to $\mathrm{S}$ and $\mathrm{G} 2$ to $\mathrm{M}$ & CDC28A/CDK1 \\
\hline Hs.34012 & NM_000059 & $B R C A 2$ & Breast cancer 2, early onset & $B R C C 2 / F A C D$ \\
\hline Hs.367437 & NM_000051 & ATM & Ataxia telangiectasia mutated & AT1/ATA \\
\hline Hs.380271 & NM_002542 & OGG1 & 8-oxoguanine DNA glycosylase & HMMH/HOGG1 \\
\hline Hs.388739 & NM_021141 & XRCC5 & $\begin{array}{l}\text { X-ray repair complementing defective repair in Chinese hamster cells } 5 \text { (double-strand-break } \\
\text { rejoining; Ku autoantigen, } 80 \mathrm{kDa} \text { ) }\end{array}$ & KARP-1/KARP1 \\
\hline Hs. 408528 & NM_000321 & RB1 & Retinoblastoma 1 (including osteosarcoma) & $O S R C / R B$ \\
\hline Hs. 431850 & NM_002745 & MAPK1 & Mitogen-activated protein kinase 1 & ERK/ERK2 \\
\hline Hs.43505 & NM_003639 & $I K B K G$ & Inhibitor of kappa light polypeptide gene enhancer in B-cells, kinase gamma & $A M C B X 1 / F I P-3$ \\
\hline Hs.437705 & NM_001789 & $C D C 25 A$ & Cell division cycle 25 homolog A (S. pombe) & $C D C 25 A 2$ \\
\hline Hs.443914 & NM_000454 & SOD1 & Superoxide dismutase 1 , soluble (amyotrophic lateral sclerosis 1 (adult)) & ALS/ALS1 \\
\hline Hs.445203 & NM_001539 & DNAJA1 & DnaJ (Hsp40) homolog, subfamily A, member 1 & $D J-2 / D j A 1$ \\
\hline Hs.460996 & NM_003789 & TRADD & TNFRSF1A-associated via death domain & Hs.89862 \\
\hline Hs.469872 & NM_000122 & ERCC3 & $\begin{array}{l}\text { Excision repair cross-complementing rodent repair deficiency, complementation group } 3 \\
\text { (xeroderma pigmentosum group B complementing) }\end{array}$ & BTF2/GTF2H \\
\hline Hs.492208 & NM_002485 & NBN & Nibrin & $A T-V 1 / A T-V 2$ \\
\hline Hs. 498248 & NM_130398 & EXO1 & Exonuclease 1 & HEX1/hEXoI \\
\hline Hs.502302 & NM_001752 & CAT & Catalase & MGC138422 \\
\hline Hs.505033 & NM_004985 & KRAS & V-Ki-ras2 Kirsten rat sarcoma viral oncogene homolog & $C-K-R A S / K-R A S 2 A$ \\
\hline Hs.505777 & NM_004083 & DDIT3 & DNA-damage-inducible transcript 3 & CEBPZ/CHOP \\
\hline
\end{tabular}


Table A2. Cont.

\begin{tabular}{|c|c|c|c|c|}
\hline UniGene & GeneBank & Symbol & Description & Gene Names \\
\hline Hs.512599 & NM_000077 & CDKN2A & Cyclin-dependent kinase inhibitor 2A (melanoma, p16, inhibits CDK4) & $A R F / C D K 4 I$ \\
\hline Hs. 514527 & NM_001168 & BIRC5 & Baculoviral IAP repeat-containing 5 (survivin) & API4/EPR-1 \\
\hline Hs.520028 & NM_005345 & HSPA1A & Heat shock $70 \mathrm{kDa}$ protein $1 \mathrm{~A}$ & HSP70-1/HSP72 \\
\hline Hs.523185 & NM_012423 & RPL13A & Ribosomal protein L13a & RPL13A \\
\hline Hs. 523560 & NM_001040141 & HSP90AA2 & Heat shock protein $90 \mathrm{kDa}$ alpha (cytosolic), class A member 2 & HSP90ALPHA/HSPCA \\
\hline Hs.523968 & NM_005426 & ТР53ВР2 & Tumor protein $p 53$ binding protein, 2 & $53 B P 2 / A S P P 2$ \\
\hline Hs.525704 & NM_002228 & JUN & Jun oncogene & AP1/c-Jun \\
\hline Hs.530227 & NM_005526 & HSF1 & Heat shock transcription factor 1 & HSTF1 \\
\hline Hs.531704 & NM_002737 & PRKCA & Protein kinase $C$, alpha & AAG6/PKC-alpha \\
\hline Hs.544577 & NM_002046 & GAPDH & Glyceraldehyde-3-phosphate dehydrogenase & G3PD/GAPD \\
\hline Hs.553498 & NM_006218 & PIK3CA & Phosphoinositide-3-kinase, catalytic, alpha polypeptide & PI3K/p110-alpha \\
\hline Hs. 567303 & NM_002392 & MDM2 & $\mathrm{Mdm} 2$, transformed $3 \mathrm{~T} 3$ cell double minute 2, p53 binding protein (mouse) & $H D M X / h d m 2$ \\
\hline Hs.567387 & NM_057749 & CCNE2 & Cyclin E2 & CYCE2 \\
\hline Hs.591084 & NM_004629 & FANCG & Fanconi anemia, complementation group $\mathrm{G}$ & $F A G / X R C C 9$ \\
\hline Hs.591980 & NM_000378 & WT1 & Wilms tumor 1 & GUD/WAGR \\
\hline Hs.592325 & NM_005432 & XRCC3 & X-ray repair complementing defective repair in Chinese hamster cells 3 & $\mathrm{XRCC} 3$ \\
\hline Hs.592839 & NM_005633 & SOS1 & Son of sevenless homolog 1 (Drosophila) & GF1/GGF1 \\
\hline Hs.61188 & NM_033276 & XRCC6BP1 & XRCC6 binding protein 1 & КUВЗ \\
\hline Hs.631709 & NM_002875 & RAD51 & RAD51 homolog (RecA homolog, E. coli) (S. cerevisiae) & BRCC5/HRAD51 \\
\hline Hs.647093 & NM_005431 & $\mathrm{XRCC} 2$ & X-ray repair complementing defective repair in Chinese hamster cells 2 & DKFZp781P0919 \\
\hline Hs.647371 & NM_005953 & MT2A & Metallothionein 2A & MT2 \\
\hline Hs.654393 & NM_005225 & E2F1 & E2F transcription factor 1 & E2F-1/RBBP3 \\
\hline Hs.654532 & NM_003263 & TLR1 & Toll-like receptor 1 & CD281/DKFZp54710610 \\
\hline Hs.655354 & NM_004584 & RAD9A & RAD9 homolog A (S. pombe) & RAD9 \\
\hline Hs.655983 & NM_001228 & CASP8 & Caspase 8 , apoptosis-related cysteine peptidase & ALPS2B/CAP4 \\
\hline Hs.656458 & NM_001556 & $I K B K B$ & Inhibitor of kappa light polypeptide gene enhancer in B-cells, kinase beta & IKK-beta/IKK2 \\
\hline Hs.695926 & NM_002890 & RASA1 & RAS p21 protein activator (GTPase activating protein) 1 & $C M-A V M / C M A V M$ \\
\hline Hs.697294 & NM_005427 & TP73 & Tumor protein $\mathrm{p} 73$ & P73 \\
\hline Hs.706746 & NM_000625 & NOS2A & Nitric oxide synthase 2A (inducible, hepatocytes) & HEP-NOS/INOS \\
\hline Hs.708288 & NM_000165 & GJA1 & Gap junction protein, alpha $1,43 \mathrm{kDa}$ & CX43/DFNB38 \\
\hline Hs.73133 & NM_005954 & MT3 & Metallothionein 3 & GIF/GIFB \\
\hline Hs.76686 & NM_000581 & GPX1 & Glutathione peroxidase 1 & GSHPX1 \\
\hline Hs.80409 & NM_001924 & GADD45A & Growth arrest and DNA-damage-inducible, alpha & DDIT1/GADD45 \\
\hline Hs. 87247 & NM_003806 & HRK & Harakiri, BCL2 interacting protein (contains only BH3 domain) & DP5/HARAKIRI \\
\hline Hs.9701 & NM_006705 & GADD45G & Growth arrest and DNA-damage-inducible, gamma & CR6/DDIT2 \\
\hline Hs.98493 & NM_006297 & $\mathrm{XRCC1}$ & X-ray repair complementing defective repair in Chinese hamster cells 1 & $R C C$ \\
\hline
\end{tabular}


Table A3. Basal gene expression in HEK shRNA RelA cells compared to the original cell line HEK-pNF-кB-d2EGFP/Neo L2 using the RT2 Profiler PCR array.

\begin{tabular}{|c|c|c|c|c|c|c|c|c|}
\hline Symbol & $\mu$ & SE & Symbol & $\mu$ & SE & Symbol & $\mu$ & SE \\
\hline$A C T B$ & 1.02 & 0.06 & $C F B$ & -1.12 & 0.13 & HSP90AA2 & 1.74 & 0.19 \\
\hline$A D M$ & 1.42 & 0.23 & CHEK1 & 1.01 & 0.16 & HSPA1A & 1.86 & 0.33 \\
\hline$A G T$ & -1.02 & 0.13 & CHEK2 & -1.11 & 0.06 & ICAM1 & 1.13 & 0.16 \\
\hline AKT1 & -1.11 & 0.10 & CSF1 & -1.24 & 0.06 & IFNB1 & -1.00 & 0.05 \\
\hline$A L D H 3 A 2$ & -1.15 & 0.03 & CSF2 & 1.06 & 0.18 & IFNG & -1.00 & 0.05 \\
\hline ATM & -1.79 & 0.02 & $C S F 2 R B$ & -1.00 & 0.05 & $I K B K B$ & -1.37 & 0.06 \\
\hline ATR & 1.40 & 0.08 & CSF3 & 1.35 & 0.20 & $I K B K E$ & -2.40 & 0.02 \\
\hline$B 2 M$ & -1.03 & 0.07 & CUL1 & 1.04 & 0.12 & $I K B K G$ & 1.10 & 0.27 \\
\hline$B C L 2 A 1$ & 1.06 & 0.11 & CXCL1 & -1.59 & 0.12 & IL10 & 1.67 & 0.43 \\
\hline$B C L 2 L 1$ & 1.08 & 0.13 & CXCL10 & -1.32 & 0.15 & IL12B & -1.15 & 0.06 \\
\hline$B C L 3$ & -1.15 & 0.21 & CXCL2 & 1.11 & 0.24 & IL15 & -1.36 & 0.11 \\
\hline BIRC2 & -1.03 & 0.09 & CXCL9 & 1.57 & 0.38 & IL1A & 1.12 & 0.17 \\
\hline BIRC3 & 1.23 & 0.30 & DDB1 & 1.21 & 0.28 & IL1B & 1.09 & 0.08 \\
\hline BIRC5 & 1.06 & 0.10 & DDIT3 & 1.62 & 0.51 & IL1R2 & -1.05 & 0.24 \\
\hline$B R C A 2$ & 1.08 & 0.12 & DNAJA1 & -1.23 & 0.09 & IL1RN & -1.00 & 0.05 \\
\hline BRCA5 & -1.04 & 0.28 & $E 2 F 1$ & 1.27 & 0.40 & IL2 & -1.00 & 0.05 \\
\hline C3 & 1.88 & 0.69 & EGFR & -1.04 & 0.11 & $I L 2 R A$ & -1.00 & 0.05 \\
\hline CASP3 & 1.27 & 0.09 & EGR1 & 2.15 & 0.30 & IL4 & 1.97 & 0.33 \\
\hline CASP8 & -1.22 & 0.30 & EGR2 & 1.30 & 0.30 & IL6 & 1.27 & 0.28 \\
\hline CASP9 & -1.07 & 0.06 & EIF2AK2 & -1.24 & 0.04 & IL8 & -2.31 & 0.13 \\
\hline$C A T$ & 1.03 & 0.22 & ERCC3 & -1.18 & 0.09 & INS & -1.00 & 0.05 \\
\hline CCL11 & 1.22 & 0.32 & EXO1 & -1.19 & 0.21 & IRF1 & -1.11 & 0.08 \\
\hline CCL2 & 1.36 & 0.11 & F3 & 1.20 & 0.15 & JUN & 4.96 & 1.85 \\
\hline CCL22 & -1.00 & 0.05 & F8 & 1.16 & 0.06 & KRAS & -1.08 & 0.02 \\
\hline CCL5 & 15.57 & 8.77 & FANCG & -1.48 & 0.04 & LIG1 & -1.18 & 0.23 \\
\hline CCND1 & -2.99 & 0.05 & FAS & -1.30 & 0.13 & $L T A$ & 1.54 & 0.33 \\
\hline CCNE1 & 1.03 & 0.08 & FASLG & 2.50 & 0.54 & $L T B$ & 1.09 & 0.25 \\
\hline CCNE2 & 1.18 & 0.23 & GADD $45 A$ & -1.27 & 0.06 & $M A P 2 K 6$ & -1.23 & 0.13 \\
\hline CCR5 & 1.53 & 0.28 & GADD $45 B$ & 3.63 & 1.08 & MAPK1 & -1.10 & 0.12 \\
\hline$C D 40$ & -1.02 & 0.15 & GADD45G & -1.17 & 0.19 & MDM2 & -1.24 & 0.11 \\
\hline CD69 & -1.00 & 0.05 & GAPDH & 1.13 & 0.07 & MMP9 & -1.03 & 0.23 \\
\hline CD80 & 1.18 & 0.26 & GJA1 & -1.22 & 0.16 & $M T 2 A$ & 1.01 & 0.07 \\
\hline CD83 & -1.50 & 0.09 & GPX1 & 1.52 & 0.17 & MT3 & 1.88 & 0.80 \\
\hline$C D C 2$ & 1.12 & 0.21 & GTF2H2 & -1.24 & 0.06 & $M Y C$ & 1.14 & 0.20 \\
\hline$C D C 25 A$ & 1.22 & 0.10 & HPRT1 & 1.21 & 0.08 & MYD88 & -1.33 & 0.17 \\
\hline CDKN1A & 1.37 & 0.31 & HRK & 1.12 & 0.48 & $N B N$ & -2.37 & 0.09 \\
\hline$C D K N 2 A$ & 1.11 & 0.06 & HSF1 & 1.06 & 0.21 & NCOA3 & 1.33 & 0.06 \\
\hline NFKB1 & 1.00 & 0.06 & $R B 1$ & 1.00 & 0.04 & TNF & -1.69 & 0.12 \\
\hline NFKB2 & 1.19 & 0.16 & REL & -1.27 & 0.04 & TNFRSF1B & 1.02 & 0.25 \\
\hline NFKBIA & -1.64 & 0.08 & RELA & -4.93 & 0.02 & TNFSF10 & -1.01 & 0.23 \\
\hline NOS2 & 1.40 & 0.32 & $R E L B$ & 1.14 & 0.22 & TP53 & -1.17 & 0.04 \\
\hline NQO1 & 1.28 & 0.19 & RPL13A & -1.12 & 0.13 & ТР53ВР2 & -1.13 & 0.10 \\
\hline$N R 4 A 2$ & 2.40 & 0.23 & RPLPO & -1.19 & 0.06 & TP73 & 1.02 & 0.09 \\
\hline OGG1 & 1.02 & 0.18 & SELE & 1.64 & 0.38 & TRADD & -1.46 & 0.04 \\
\hline P53AIP1 & 1.45 & 0.30 & SELP & -1.00 & 0.05 & TRAF2 & -1.12 & 0.03 \\
\hline PCNA & 1.28 & 0.16 & SNAP25 & 1.79 & 0.38 & UNG & 1.66 & 0.18 \\
\hline PDGFB & -1.00 & 0.05 & SOD1 & 1.21 & 0.15 & VCAM1 & -1.00 & 0.05 \\
\hline PIK3Ca & 1.13 & 0.07 & SOD2 & -1.09 & 0.06 & WT1 & 1.25 & 0.19 \\
\hline PLAU & -1.52 & 0.14 & SOD3 & 2.03 & 0.75 & XIAP & -1.10 & 0.12 \\
\hline PRKCA & -1.03 & 0.12 & SOS1 & -1.11 & 0.13 & $X R C C 1$ & 1.01 & 0.09 \\
\hline PTGS2 & 1.96 & 0.38 & STAT1 & 1.25 & 0.05 & $X R C C 2$ & -1.52 & 0.07 \\
\hline RAD51 & 1.02 & 0.05 & STAT3 & -1.10 & 0.04 & $X R C C 3$ & 1.04 & 0.31 \\
\hline RAD9A & 1.04 & 0.04 & STAT5B & -1.08 & 0.09 & $X R C C 5$ & 1.10 & 0.11 \\
\hline RASA1 & -1.24 & 0.05 & TLR1 & 1.15 & 0.03 & XRCC6BP1 & -1.20 & 0.10 \\
\hline
\end{tabular}


Table A4. TNF- $\alpha$ induced gene expression in HEK shRNA RelA cells (RelA k.d.) compared to the original cell line HEK-pNF-kB-d2EGFP/Neo L2 (HEK wt) using the RT2 Profiler PCR array.

\begin{tabular}{|c|c|c|c|c|}
\hline \multirow[b]{2}{*}{ Symbol } & \multicolumn{2}{|c|}{ HEK wt } & \multicolumn{2}{|c|}{ RelA k.d. } \\
\hline & $\mu$ & SE & $\mu$ & SE \\
\hline$A C T B$ & -1.19 & 0.05 & -1.26 & 0.07 \\
\hline$A D M$ & -1.88 & 0.08 & 1.39 & 0.27 \\
\hline$A G T$ & 1.57 & 0.42 & -1.06 & 0.11 \\
\hline AKT1 & -1.36 & 0.08 & 1.04 & 0.16 \\
\hline$A L D H 3 A 2$ & -1.19 & 0.02 & -1.23 & 0.03 \\
\hline ATM & -1.01 & 0.03 & 1.19 & 0.06 \\
\hline ATR & -1.50 & 0.05 & 1.35 & 0.03 \\
\hline$B 2 M$ & 1.58 & 0.14 & 1.27 & 0.07 \\
\hline$B C L 2 A 1$ & 2.22 & 0.32 & 1.47 & 0.20 \\
\hline$B C L 2 L 1$ & 1.65 & 0.19 & 1.17 & 0.08 \\
\hline$B C L 3$ & 2.38 & 0.44 & 1.67 & 0.47 \\
\hline BIRC2 & 1.54 & 0.13 & 1.27 & 0.12 \\
\hline BIRC3 & 4.76 & 0.98 & 2.03 & 0.47 \\
\hline BIRC5 & -1.36 & 0.10 & -1.09 & 0.01 \\
\hline$B R C A 2$ & 1.21 & 0.07 & 1.48 & 0.22 \\
\hline BRCA5 & 2.04 & 0.67 & 1.47 & 0.33 \\
\hline C3 & 5.97 & 1.39 & 1.97 & 0.57 \\
\hline CASP3 & -1.04 & 0.10 & 1.44 & 0.02 \\
\hline CASP8 & 1.97 & 0.74 & 1.80 & 0.56 \\
\hline CASPO & 1.08 & 0.07 & -1.02 & 0.05 \\
\hline$C A T$ & -1.44 & 0.18 & -1.18 & 0.11 \\
\hline CCL11 & 3.73 & 1.51 & 1.84 & 0.57 \\
\hline CCL2 & 3.04 & 0.24 & -1.28 & 0.09 \\
\hline CCL22 & 1.39 & 0.24 & -1.15 & 0.04 \\
\hline CCL5 & 4.79 & 1.79 & 29.02 & 12.66 \\
\hline CCND1 & -2.35 & 0.11 & -1.55 & 0.09 \\
\hline CCNE1 & -1.13 & 0.09 & -1.10 & 0.04 \\
\hline CCNE2 & 1.40 & 0.33 & 1.56 & 0.22 \\
\hline CCR5 & 1.61 & 0.49 & -2.87 & 0.06 \\
\hline CD40 & 2.83 & 0.53 & 1.51 & 0.30 \\
\hline CD69 & 3.37 & 0.23 & -1.15 & 0.04 \\
\hline CD80 & 2.06 & 0.50 & 2.32 & 0.77 \\
\hline CD83 & 5.68 & 0.82 & 1.67 & 0.08 \\
\hline$C D C 2$ & 1.16 & 0.16 & 1.38 & 0.31 \\
\hline$C D C 25 A$ & 1.25 & 0.02 & -1.04 & 0.11 \\
\hline CDKN1A & 2.85 & 0.50 & 2.59 & 0.59 \\
\hline CDKN2A & -1.35 & 0.04 & -1.14 & 0.04 \\
\hline$C F B$ & 2.21 & 0.36 & 1.36 & 0.17 \\
\hline CHEK1 & 1.35 & 0.25 & 1.15 & 0.15 \\
\hline CHEK2 & 1.18 & 0.06 & 1.14 & 0.09 \\
\hline CSF1 & 2.55 & 0.25 & -1.14 & 0.02 \\
\hline CSF2 & 1.16 & 0.37 & -1.32 & 0.10 \\
\hline$C S F 2 R B$ & -1.07 & 0.05 & -1.15 & 0.04 \\
\hline CSF3 & 1.07 & 0.30 & 1.13 & 0.21 \\
\hline CUL1 & 1.08 & 0.15 & -1.09 & 0.06 \\
\hline CXCL1 & 47.46 & 11.75 & -1.05 & 0.08 \\
\hline CXCL10 & 23.38 & 5.72 & -1.18 & 0.06 \\
\hline CXCL2 & 18.29 & 3.92 & 1.72 & 0.33 \\
\hline CXCL9 & 2.08 & 0.62 & 1.72 & 0.45 \\
\hline DDB1 & -1.10 & 0.27 & -1.33 & 0.10 \\
\hline DDIT3 & 1.88 & 0.63 & 1.91 & 0.50 \\
\hline$D N A J A 1$ & 1.48 & 0.24 & 1.07 & 0.02 \\
\hline$E 2 F 1$ & -1.31 & 0.28 & -1.28 & 0.18 \\
\hline$E G F R$ & 1.80 & 0.20 & 1.33 & 0.14 \\
\hline EGR1 & -1.06 & 0.18 & 1.23 & 0.03 \\
\hline EGR2 & 1.98 & 0.57 & 1.81 & 0.47 \\
\hline$E I F 2 A K 2$ & 1.06 & 0.06 & 1.09 & 0.04 \\
\hline ERCC3 & 1.26 & 0.01 & 1.12 & 0.17 \\
\hline EXO1 & 1.97 & 0.67 & -4.29 & 0.02 \\
\hline$F 3$ & 2.66 & 0.30 & 1.66 & 0.22 \\
\hline F8 & -1.23 & 0.10 & 1.26 & 0.02 \\
\hline FANCG & 1.26 & 0.08 & 1.18 & 0.05 \\
\hline
\end{tabular}


Table A4. Cont.

\begin{tabular}{|c|c|c|c|c|}
\hline \multirow[b]{2}{*}{ Symbol } & \multicolumn{2}{|c|}{ HEK wt } & \multicolumn{2}{|c|}{ RelA k.d. } \\
\hline & $\mu$ & SE & $\mu$ & SE \\
\hline FAS & -1.39 & 0.13 & -1.13 & 0.16 \\
\hline FASLG & 1.28 & 0.47 & -1.01 & 0.18 \\
\hline GADD $45 A$ & 1.38 & 0.15 & 1.86 & 0.00 \\
\hline$G A D D 45 B$ & 2.01 & 0.56 & 2.60 & 0.91 \\
\hline GADD45G & -1.01 & 0.24 & 1.12 & 0.20 \\
\hline GAPDH & -1.29 & 0.06 & -1.32 & 0.04 \\
\hline GJA1 & -1.03 & 0.12 & -1.46 & 0.17 \\
\hline GPX1 & -1.17 & 0.13 & -1.34 & 0.03 \\
\hline GTF2H2 & 1.42 & 0.02 & 1.24 & 0.13 \\
\hline HPRT1 & -1.13 & 0.07 & 1.40 & 0.17 \\
\hline$H R K$ & 2.12 & 0.76 & 2.45 & 1.08 \\
\hline HSF1 & 1.60 & 0.44 & -1.00 & 0.07 \\
\hline HSP90AA2 & 1.17 & 0.16 & 1.05 & 0.07 \\
\hline HSPA1A & -1.51 & 0.15 & -1.04 & 0.08 \\
\hline ICAM1 & 2.12 & 0.36 & -2.56 & 0.05 \\
\hline IFNB1 & -1.01 & 0.05 & -1.15 & 0.04 \\
\hline IFNG & -1.36 & 0.17 & -1.15 & 0.04 \\
\hline$I K B K B$ & 1.20 & 0.14 & 1.05 & 0.00 \\
\hline IKBKE & 1.22 & 0.08 & -1.83 & 0.03 \\
\hline$I K B K G$ & 1.01 & 0.33 & -1.75 & 0.06 \\
\hline IL10 & 1.41 & 0.26 & -1.80 & 0.17 \\
\hline IL12B & 1.82 & 0.32 & 1.42 & 0.07 \\
\hline IL15 & 2.83 & 0.63 & 1.59 & 0.07 \\
\hline IL1A & 1.59 & 0.19 & 1.38 & 0.23 \\
\hline IL1B & -1.10 & 0.07 & 1.27 & 0.12 \\
\hline IL1R2 & 4.02 & 1.29 & 1.71 & 0.30 \\
\hline IL1RN & 1.39 & 0.24 & -1.15 & 0.04 \\
\hline IL2 & -1.27 & 0.13 & -1.15 & 0.04 \\
\hline IL2RA & 1.35 & 0.21 & -1.15 & 0.04 \\
\hline IL4 & 1.62 & 0.43 & -1.12 & 0.14 \\
\hline IL6 & 1.01 & 0.23 & 1.05 & 0.18 \\
\hline IL6 & 1.86 & 0.58 & 2.39 & 0.50 \\
\hline IL8 & 17.83 & 5.19 & -1.15 & 0.04 \\
\hline INS & -1.27 & 0.12 & 1.29 & 0.11 \\
\hline IRF1 & 3.16 & 0.40 & -1.18 & 0.12 \\
\hline JUN & 1.39 & 0.69 & 1.15 & 0.01 \\
\hline$K R A S$ & 1.11 & 0.02 & -1.42 & 0.10 \\
\hline LIG1 & -1.24 & 0.29 & 1.58 & 0.38 \\
\hline LTA & 1.52 & 0.51 & 2.06 & 0.67 \\
\hline$L T B$ & 1.92 & 0.58 & -1.80 & 0.13 \\
\hline МAP2K6 & -1.57 & 0.12 & -1.08 & 0.11 \\
\hline MAPK1 & -1.13 & 0.13 & 1.02 & 0.13 \\
\hline MDM2 & -1.01 & 0.13 & 2.01 & 0.37 \\
\hline MMP9 & 3.34 & 0.61 & -1.53 & 0.06 \\
\hline$M T 2 A$ & -1.13 & 0.02 & -1.04 & 0.45 \\
\hline MT3 & 1.86 & 0.58 & -1.10 & 0.16 \\
\hline$M Y C$ & -1.84 & 0.08 & 2.09 & 0.70 \\
\hline MYD88 & 1.49 & 0.35 & 1.01 & 0.29 \\
\hline$N B N$ & -1.18 & 0.06 & 1.12 & 0.08 \\
\hline NCOA3 & -1.02 & 0.06 & 1.22 & 0.04 \\
\hline NFKB1 & 2.88 & 0.28 & 1.47 & 0.13 \\
\hline NFKB2 & 2.90 & 0.61 & 1.79 & 0.40 \\
\hline NFKBIA & 11.88 & 1.66 & 2.52 & 0.30 \\
\hline NOS2 & 1.91 & 0.52 & 1.32 & 0.20 \\
\hline NQO1 & -1.76 & 0.10 & -1.10 & 0.05 \\
\hline$N R 4 A 2$ & 1.17 & 0.18 & 1.22 & 0.21 \\
\hline OGG1 & -1.19 & 0.10 & -1.19 & 0.19 \\
\hline P53AIP1 & 1.64 & 0.09 & 1.42 & 0.41 \\
\hline PCNA & 1.36 & 0.14 & 1.25 & 0.18 \\
\hline PDGFB & 1.17 & 0.12 & -1.15 & 0.04 \\
\hline PIK3Ca & 1.20 & 0.08 & 1.19 & 0.06 \\
\hline PLAU & 3.35 & 0.57 & 2.64 & 0.58 \\
\hline PRKCA & -1.00 & 0.17 & -1.21 & 0.05 \\
\hline PTGS2 & 3.99 & 0.53 & 2.17 & 0.39 \\
\hline
\end{tabular}


Table A4. Cont.

\begin{tabular}{lcccc}
\hline & \multicolumn{2}{c}{ HEK wt } & \multicolumn{2}{c}{ RelA k.d. } \\
\hline Symbol & $\mu$ & SE & $\mu$ & SE \\
\hline RAD51 & -1.00 & 0.02 & 1.00 & 0.07 \\
RAD9A & 1.10 & 0.02 & -1.31 & 0.04 \\
RASA1 & 1.11 & 0.07 & 1.27 & 0.07 \\
RB1 & 1.07 & 0.03 & 1.08 & 0.05 \\
REL & 2.40 & 0.25 & 1.33 & 0.07 \\
RELA & 1.69 & 0.17 & -1.11 & 0.06 \\
RELB & 1.82 & 0.55 & 1.21 & 0.23 \\
RPL13A & -1.29 & 0.09 & -1.12 & 0.15 \\
RPLP0 & 1.46 & 0.12 & 1.10 & 0.05 \\
SELE & 1.86 & 0.71 & 1.06 & 0.19 \\
SELP & 1.17 & 0.11 & -1.15 & 0.04 \\
SNAP25 & 1.48 & 0.31 & 2.06 & 0.64 \\
SOD1 & -1.28 & 0.13 & -1.16 & 0.05 \\
SOD2 & -1.17 & 0.09 & -1.10 & 0.06 \\
SOD3 & 1.86 & 0.58 & -1.42 & 0.27 \\
SOS1 & 1.25 & 0.19 & 1.08 & 0.14 \\
STAT1 & 1.07 & 0.11 & 1.01 & 0.04 \\
STAT3 & -1.15 & 0.09 & 1.02 & 0.06 \\
STAT5B & 1.35 & 0.18 & 1.28 & 0.17 \\
TLR1 & -1.40 & 0.01 & -2.09 & 0.02 \\
TNF & 60.95 & 12.42 & 3.40 & 0.54 \\
TNFRSF1B & 1.49 & 0.34 & 4.13 & 2.29 \\
TNFSF10 & 1.73 & 0.37 & 2.07 & 0.78 \\
TP53 & 1.17 & 0.05 & 1.16 & 0.06 \\
TP53BP2 & 1.31 & 0.17 & -1.00 & 0.09 \\
TP73 & 1.11 & 0.12 & -2.03 & 0.04 \\
TRADD & 1.09 & 0.06 & -1.42 & 0.04 \\
TRAF2 & 1.23 & 0.11 & 1.04 & 0.05 \\
UNG & -1.23 & 0.12 & -1.09 & 0.05 \\
VCAM1 & -1.36 & 0.15 & -1.15 & 0.04 \\
WT1 & 1.20 & 0.01 & -1.64 & 0.13 \\
XIAP & 1.50 & 0.21 & 1.37 & 0.17 \\
XRCC1 & 1.04 & 0.13 & -1.17 & 0.02 \\
XRCC2 & 1.17 & 0.14 & 1.42 & 0.11 \\
XRCC3 & -1.28 & 0.27 & -1.65 & 0.13 \\
XRCC5 & -1.17 & 0.12 & 1.05 & 0.01 \\
XRCC6BP1 & -1.08 & 0.02 & -1.09 & 0.15 \\
\hline & & & &
\end{tabular}

Table A5. Relative gene expression in HEK-pNF-кB-d2EGFP/Neo L2 (HEK wt) and HEK shRNA RelA (RelA k.d.) cells after irradiation using the RT2 Profiler PCR array: X-rays.

\begin{tabular}{|c|c|c|c|c|c|c|c|c|c|c|c|c|}
\hline \multirow[b]{3}{*}{ Symbol } & \multicolumn{6}{|c|}{ HEK wt } & \multicolumn{6}{|c|}{ RelA k.d. } \\
\hline & \multicolumn{2}{|c|}{$0.5 \mathrm{~Gy}$} & \multicolumn{2}{|c|}{$4 \mathrm{~Gy}$} & \multicolumn{2}{|c|}{$8 \mathrm{~Gy}$} & \multicolumn{2}{|c|}{$0.5 \mathrm{~Gy}$} & \multicolumn{2}{|c|}{$4 \mathrm{~Gy}$} & \multicolumn{2}{|c|}{$8 \mathrm{~Gy}$} \\
\hline & $\mu$ & $\mathrm{SE}$ & $\mu$ & $\mathrm{SE}$ & $\mu$ & SE & $\mu$ & SE & $\mu$ & SE & $\mu$ & SE \\
\hline$A D M$ & -1.09 & 0.11 & -1.04 & 0.09 & -1.16 & 0.08 & 1.02 & 0.20 & 1.18 & 0.23 & 1.15 & 0.22 \\
\hline$A G T$ & -1.35 & 0.23 & 1.80 & 0.57 & 1.56 & 0.47 & 1.07 & 0.12 & 1.17 & 0.13 & -1.00 & 0.11 \\
\hline AKT1 & 1.08 & 0.06 & 1.05 & 0.05 & 1.12 & 0.05 & 1.22 & 0.19 & 1.31 & 0.20 & 1.29 & 0.20 \\
\hline$A L D H 3 A 2$ & 1.16 & 0.04 & 1.01 & 0.07 & -1.08 & 0.06 & 1.06 & 0.04 & -1.03 & 0.04 & -1.01 & 0.04 \\
\hline$B C L 2 A 1$ & 1.15 & 0.19 & 1.31 & 0.15 & -1.15 & 0.12 & -1.02 & 0.13 & 1.45 & 0.19 & 1.04 & 0.14 \\
\hline$B C L 2 L 1$ & 1.01 & 0.11 & -1.18 & 0.09 & -1.12 & 0.13 & -1.41 & 0.05 & 1.21 & 0.09 & -1.24 & 0.06 \\
\hline BIRC2 & -1.17 & 0.06 & -1.14 & 0.04 & 1.02 & 0.07 & -1.37 & 0.07 & -1.02 & 0.09 & -1.08 & 0.08 \\
\hline BIRC3 & -1.31 & 0.11 & 1.96 & 0.38 & 2.53 & 0.29 & -1.86 & 0.12 & -1.02 & 0.23 & -1.22 & 0.19 \\
\hline C3 & 1.98 & 0.32 & 1.98 & 0.32 & 1.05 & 0.14 & -1.72 & 0.17 & 1.43 & 0.42 & 1.20 & 0.35 \\
\hline CCL11 & 1.40 & 0.57 & 2.66 & 0.78 & 2.63 & 0.77 & 1.88 & 0.58 & 1.90 & 0.59 & 1.23 & 0.38 \\
\hline CCL2 & -1.21 & 0.08 & 1.24 & 0.15 & 2.25 & 0.20 & 1.25 & 0.15 & 1.10 & 0.13 & 1.04 & 0.12 \\
\hline CCL22 & 1.73 & 0.32 & 1.14 & 0.31 & 1.08 & 0.24 & 1.08 & 0.05 & 1.17 & 0.06 & 1.15 & 0.05 \\
\hline CCL5 & -1.42 & 0.24 & 3.68 & 1.53 & 3.34 & 1.40 & 1.55 & 0.68 & 2.07 & 0.90 & -1.47 & 0.30 \\
\hline CCND1 & 1.02 & 0.19 & 1.15 & 0.18 & 1.20 & 0.18 & 1.46 & 0.21 & 2.16 & 0.30 & 2.13 & 0.30 \\
\hline CCR5 & -1.34 & 0.28 & 1.78 & 0.61 & 1.49 & 0.44 & 1.55 & 0.28 & 1.52 & 0.27 & -1.01 & 0.18 \\
\hline
\end{tabular}


Table A5. Cont.

\begin{tabular}{|c|c|c|c|c|c|c|c|c|c|c|c|c|}
\hline \multirow[b]{3}{*}{ Symbol } & \multicolumn{6}{|c|}{ HEK wt } & \multicolumn{6}{|c|}{ RelA k.d. } \\
\hline & \multicolumn{2}{|c|}{$0.5 \mathrm{~Gy}$} & \multicolumn{2}{|c|}{$4 \mathrm{~Gy}$} & \multicolumn{2}{|c|}{$8 \mathrm{~Gy}$} & \multicolumn{2}{|c|}{$0.5 \mathrm{~Gy}$} & \multicolumn{2}{|c|}{4 Gy } & \multicolumn{2}{|c|}{$8 \mathrm{~Gy}$} \\
\hline & $\mu$ & SE & $\mu$ & SE & $\mu$ & SE & $\mu$ & SE & $\mu$ & SE & $\mu$ & SE \\
\hline$C D 40$ & 1.09 & 0.18 & 1.27 & 0.15 & 1.21 & 0.16 & -1.02 & 0.19 & 1.42 & 0.28 & -1.14 & 0.17 \\
\hline CD69 & 1.28 & 0.10 & 1.14 & 0.11 & -1.01 & 0.08 & 1.08 & 0.05 & 1.17 & 0.06 & 1.15 & 0.05 \\
\hline CD80 & -1.63 & 0.17 & 1.45 & 0.35 & 1.29 & 0.25 & -1.34 & 0.25 & 2.42 & 0.80 & -1.35 & 0.24 \\
\hline CD83 & -1.01 & 0.03 & 2.47 & 0.08 & 3.75 & 0.18 & 1.12 & 0.06 & 1.67 & 0.08 & 2.27 & 0.11 \\
\hline CDKN1A & 1.41 & 0.19 & 1.81 & 0.19 & 1.84 & 0.21 & 1.17 & 0.33 & 1.58 & 0.45 & 2.04 & 0.58 \\
\hline$C F B$ & 1.21 & 0.14 & -1.09 & 0.08 & -1.20 & 0.09 & -1.33 & 0.09 & -1.39 & 0.09 & -1.15 & 0.11 \\
\hline CSF1 & 1.31 & 0.12 & 1.52 & 0.13 & 1.92 & 0.14 & 1.13 & 0.02 & 1.28 & 0.03 & 1.30 & 0.03 \\
\hline CSF2 & -1.49 & 0.27 & -1.02 & 0.32 & 1.30 & 0.46 & 1.44 & 0.19 & 1.41 & 0.19 & -1.06 & 0.13 \\
\hline$C S F 2 R B$ & 1.07 & 0.08 & -1.00 & 0.08 & -1.13 & 0.06 & 1.08 & 0.05 & 1.17 & 0.06 & 1.15 & 0.05 \\
\hline CSF3 & -1.55 & 0.22 & 1.53 & 0.54 & 1.82 & 0.62 & 1.26 & 0.23 & 1.03 & 0.19 & -1.31 & 0.14 \\
\hline CXCL1 & 1.04 & 0.20 & 3.57 & 0.56 & 6.96 & 1.01 & 1.06 & 0.09 & 1.52 & 0.12 & 2.02 & 0.16 \\
\hline CXCL10 & -1.10 & 0.16 & 4.68 & 0.60 & 14.58 & 2.57 & 1.05 & 0.08 & 2.23 & 0.16 & 2.04 & 0.15 \\
\hline CXCL2 & -1.35 & 0.13 & 2.33 & 0.33 & 3.01 & 0.40 & -1.04 & 0.19 & 1.55 & 0.30 & 1.29 & 0.25 \\
\hline CXCL9 & -2.11 & 0.17 & 1.58 & 0.56 & 1.75 & 0.48 & -1.43 & 0.18 & .38 & 0.36 & -1.25 & 0.21 \\
\hline EGFR & 1.25 & 0.12 & 1.43 & 0.11 & & 0.13 & -1.10 & 0.10 & .04 & 0.11 & -1.07 & 0.10 \\
\hline EGR2 & 1.77 & 0.19 & 1.03 & 0.24 & 1.32 & 0. & -1.65 & 0.16 & .95 & 1 & -1.02 & 0.26 \\
\hline F3 & 1.05 & 0.11 & 1.3 & & & & 1.13 & & 1.31 & & 1.67 & 0.22 \\
\hline F8 & -1.39 & 0.10 & -1.36 & 0. & -1.45 & 0. & -1.35 & & -1.55 & & -1.48 & 0.01 \\
\hline FAS & 1.35 & 0.30 & 1.31 & 0.21 & 1.57 & & 1.68 & & 1.85 & & 1.86 & 0.34 \\
\hline FASLG & -1.78 & 0.25 & 1.81 & 0.77 & 2. & 0.97 & 1.28 & 0.23 & 1.40 & 0.25 & -1.61 & 0.11 \\
\hline$G A D D 45 B$ & -1.83 & 0.17 & 1.66 & 0.49 & 1.50 & 0.37 & -1.30 & 0.27 & -1.43 & 0.24 & -1.60 & 0.22 \\
\hline ICAM1 & 1.46 & 0.24 & 1.29 & 0.17 & 1.03 & 0.16 & -1.02 & 0.12 & -1.00 & 0.12 & 1.11 & 0.14 \\
\hline IFNB1 & 1.12 & 0.07 & 1.27 & 0.06 & -1.27 & 0.09 & 1.08 & 0.05 & 1.17 & 0.06 & 1.15 & 0.05 \\
\hline IFNG & -1.32 & 0.22 & 1.44 & 0.39 & 1.41 & 0.41 & 1.08 & 0.05 & 1.17 & 0.06 & 1.15 & 0.05 \\
\hline IL12B & -1.36 & 0.16 & 1.45 & 0.33 & 1.64 & 0.31 & -1.02 & 0.05 & 2.01 & 0.10 & 3 & 0.05 \\
\hline IL15 & 1.14 & 0.23 & 2.22 & 0.58 & 2.31 & 0 & 1.08 & 0.05 & 46 & 0.06 & .55 & 0.07 \\
\hline IL1A & -1.52 & 0.11 & -1.33 & 0. & -1 & & -1.70 & 0. & 6 & 0.27 & -1.24 & 0.17 \\
\hline$I L 1 B$ & 1.03 & 0.0 & -1.12 & & -1 & & 1.02 & & 0 & 0. & 1.08 & 0.10 \\
\hline IL1R2 & -1.80 & 0.16 & -1.00 & & -1.29 & 0. & -1.27 & & 1 & 0 & -1.13 & 0.16 \\
\hline$I L 1 R N$ & 1.73 & 0.3 & & & & & & & & & 115 & 0.05 \\
\hline IL2 & -1.16 & 0.18 & & 0.19 & & & 1.08 & 0.05 & 1.17 & 0.06 & 1.10 & 0.05 \\
\hline$I L 2 R$ & 1.67 & 0.28 & & 0.27 & & & 1.08 & 0.05 & 1.17 & 0.06 & 1.15 & 0.05 \\
\hline IL4 & -1.36 & 0.23 & 1.51 & 0.46 & 1.20 & 0.33 & 1.10 & 0.18 & -1.17 & 0.14 & -1.60 & 0.10 \\
\hline IL6 & -1.30 & 0.22 & 1.75 & 0.51 & 1.53 & 0.45 & 1.19 & 0.12 & 1.09 & 0.11 & 1.07 & 0.11 \\
\hline IL8 & -1.73 & 0.19 & 2.42 & 0.66 & 3.74 & 0.86 & 1.20 & 0.19 & 1.38 & 0.22 & 1.01 & 0.16 \\
\hline INS & -1.16 & 0.17 & 1.22 & 0.20 & 1.48 & 0.34 & 1.08 & 0.05 & 1.17 & 0.06 & 1.15 & 0.05 \\
\hline IRF1 & 1.27 & 0.14 & 1.45 & 0.15 & 2.19 & 0.25 & 1.08 & 0.09 & 1.41 & 0.12 & 1.56 & 0.13 \\
\hline LTA & 1.19 & 0.3 & & 0. & & & -1.29 & 0.19 & 1.86 & 0. & 00 & 0.24 \\
\hline$L T B$ & 1.87 & 0.20 & 1.23 & 0. & 1 . & 0. & -1.54 & 0.21 & 2.67 & 0.87 & 1.30 & 0.42 \\
\hline$M A P$ & -1.20 & 0.1 & -1.91 & 0. & -2.78 & 0. & -1.15 & 0.2 & -1.09 & 0.22 & -1.02 & 0.24 \\
\hline MMP9 & -1.37 & 0.0 & -1.36 & 0.03 & -1.48 & 0.03 & -1.42 & 0. & -1.28 & 0.14 & -1.18 & 0.16 \\
\hline$M Y C$ & & 0.05 & -1.02 & 0. & -1.22 & & & & -1.24 & 0.14 & -1.24 & 0.14 \\
\hline MYD88 & -1.89 & 0.14 & 1.24 & 0.36 & 1.13 & 0.27 & 1.57 & 0.53 & 1.60 & 0.54 & 1.41 & 0.47 \\
\hline NCOA3 & 1.04 & 0.08 & -1.15 & 0.05 & -1.20 & 0.05 & -1.13 & 0.06 & -1.11 & 0.06 & -1.33 & 0.05 \\
\hline NFKB1 & -1.08 & 0.13 & 1.62 & 0.17 & 2.73 & 0.30 & 1.17 & 0.03 & 1.21 & 0.04 & 1.31 & 0.04 \\
\hline NFKB2 & 1.01 & 0.12 & 2.93 & 0.33 & 4.07 & 0.45 & 1.09 & 0.18 & 1.48 & 0.24 & 1.62 & 0.26 \\
\hline NFKBIA & -1.07 & 0.08 & 2.65 & 0.34 & 4.26 & 0.40 & -1.13 & 0.10 & 1.47 & 0.17 & 1.69 & 0.19 \\
\hline NQO1 & 1.10 & 0.12 & -1.10 & 0.12 & -1.17 & 0.10 & 1.18 & 0.06 & 1.21 & 0.06 & 1.49 & 0.08 \\
\hline$N R 4 A 2$ & 1.43 & 0.25 & -1.10 & 0.19 & 1.03 & 0.23 & -1.02 & 0.17 & 1.08 & 0.19 & 1.73 & 0.30 \\
\hline$P D G F B$ & 1.41 & 0.16 & 1.13 & 0.17 & -1.02 & 0.14 & 1.08 & 0.05 & 1.17 & 0.06 & 1.15 & 0.05 \\
\hline PLAU & -1.11 & 0.15 & 2.09 & 0.49 & 2.18 & 0.41 & 1.22 & 0.27 & 1.26 & 0.28 & -1.29 & 0.17 \\
\hline PTGS2 & -1.03 & 0.03 & 1.41 & 0.03 & 1.77 & 0.05 & -1.62 & 0.11 & -1.21 & 0.15 & -1.35 & 0.13 \\
\hline$R E L$ & 1.10 & 0.1 & 1.02 & 0.14 & 1.40 & & -1.32 & 0.04 & -1.07 & 0.05 & -1.07 & 0.05 \\
\hline RELA & & 0.06 & 1.07 & 0.04 & 1.1 & 0.05 & 1.00 & 0.06 & 1.14 & 0.07 & 1.05 & 0.06 \\
\hline RELB & -1.73 & 0.21 & 1.68 & 0.60 & 1.87 & 0.51 & -1.13 & 0.17 & 1.09 & 0.20 & 1.02 & 0.19 \\
\hline SELE & -1.79 & 0.25 & 1.70 & 0.68 & 1.92 & 0.71 & 1.36 & 0.24 & 1.32 & 0.24 & -1.41 & 0.13 \\
\hline SELP & 1.41 & 0.15 & -1.01 & 0.21 & -1.08 & 0.15 & 1.08 & 0.05 & 1.17 & 0.06 & 1.15 & 0.05 \\
\hline SNAP25 & 1.05 & 0.26 & 1.21 & 0.22 & 1.06 & 0.19 & 1.59 & 0.49 & 1.86 & 0.58 & 1.96 & 0.61 \\
\hline SOD2 & -1.05 & 0.07 & -1.08 & 0.05 & -1.00 & 0.07 & -1.03 & 0.09 & 1.02 & 0.10 & 1.15 & 0.11 \\
\hline STAT1 & 1.15 & 0.14 & -1.17 & 0.09 & -1.10 & 0.10 & -1.08 & 0.04 & -1.14 & 0.04 & -1.25 & 0.03 \\
\hline STAT3 & -1.14 & 0.10 & 1.03 & 0.11 & 1.12 & 0.13 & -1.13 & 0.06 & -1.15 & 0.05 & -1.16 & 0.05 \\
\hline
\end{tabular}


Table A5. Cont.

\begin{tabular}{|c|c|c|c|c|c|c|c|c|c|c|c|c|}
\hline \multirow[b]{3}{*}{ Symbol } & \multicolumn{6}{|c|}{ HEK wt } & \multicolumn{6}{|c|}{ RelA k.d. } \\
\hline & \multicolumn{2}{|c|}{$0.5 \mathrm{~Gy}$} & \multicolumn{2}{|c|}{$4 \mathrm{~Gy}$} & \multicolumn{2}{|c|}{$8 \mathrm{~Gy}$} & \multicolumn{2}{|c|}{$0.5 \mathrm{~Gy}$} & \multicolumn{2}{|c|}{$4 \mathrm{~Gy}$} & \multicolumn{2}{|c|}{$8 \mathrm{~Gy}$} \\
\hline & $\mu$ & SE & $\mu$ & SE & $\mu$ & SE & $\mu$ & SE & $\mu$ & SE & $\mu$ & SE \\
\hline STAT5B & 1.08 & 0.16 & 1.33 & 0.19 & 1.24 & 0.15 & 1.00 & 0.13 & -1.08 & 0.12 & -1.17 & 0.11 \\
\hline TNF & 1.01 & 0.11 & 5.10 & 0.99 & 12.90 & 1.72 & 1.08 & 0.05 & 1.17 & 0.06 & 1.15 & 0.05 \\
\hline TNFRSF1B & -1.81 & 0.16 & 1.02 & 0.22 & 1.11 & 0.22 & -2.15 & 0.26 & 4.10 & 2.28 & 2.39 & 1.33 \\
\hline TNFSF10 & -1.48 & 0.17 & 1.11 & 0.21 & -1.02 & 0.18 & -1.61 & 0.23 & 2.81 & 1.06 & 1.64 & 0.62 \\
\hline ТР53 & 1.13 & 0.02 & 1.39 & 0.04 & 1.67 & 0.08 & -1.14 & 0.02 & -1.02 & 0.02 & -1.04 & 0.02 \\
\hline TRAF2 & 1.06 & 0.11 & 1.04 & 0.09 & 1.12 & 0.10 & 1.10 & 0.05 & -1.10 & 0.04 & -1.03 & 0.04 \\
\hline VCAM1 & -1.27 & 0.20 & 4.24 & 1.56 & 2.94 & 0.87 & 1.08 & 0.05 & 1.17 & 0.06 & 1.15 & 0.05 \\
\hline XIAP & -1.07 & 0.11 & -1.18 & 0.09 & -1.23 & 0.07 & -1.13 & 0.11 & -1.17 & 0.10 & -1.27 & 0.10 \\
\hline ACTB & 1.12 & 0.10 & -1.16 & 0.08 & -1.08 & 0.07 & 1.21 & 0.17 & 1.08 & 0.16 & -1.04 & 0.14 \\
\hline$B 2 M$ & -1.05 & 0.07 & 1.29 & 0.14 & 1.29 & 0.09 & -1.09 & 0.04 & -1.06 & 0.04 & 1.08 & 0.04 \\
\hline GAPDH & -1.14 & 0.04 & -1.03 & 0.04 & -1.10 & 0.05 & 1.03 & 0.05 & -1.06 & 0.05 & -1.17 & 0.04 \\
\hline HPRT1 & 1.04 & 0.04 & 1.01 & 0.03 & -1.02 & 0.04 & -1.08 & 0.12 & 1.10 & 0.14 & 1.21 & 0.16 \\
\hline RPLPO & 1.06 & 0.05 & 1.03 & 0.07 & 1.01 & 0.05 & 1.01 & 0.05 & 1.00 & 0.05 & -1.01 & 0.05 \\
\hline
\end{tabular}

Table A6. Relative gene expression in HEK-pNF-кB-d2EGFP/Neo L2 (HEK wt) and HEK shRNA RelA (RelA k.d.) cells after irradiation using the RT2 Profiler PCR array: Ti ions.

\begin{tabular}{|c|c|c|c|c|c|c|c|c|}
\hline \multirow[b]{3}{*}{ Symbol } & \multicolumn{4}{|c|}{ HEK wt } & \multicolumn{4}{|c|}{ RelA k.d. } \\
\hline & \multicolumn{2}{|c|}{$0.5 \mathrm{~Gy}$} & \multicolumn{2}{|c|}{$4 \mathrm{~Gy}$} & \multicolumn{2}{|c|}{$0.5 \mathrm{~Gy}$} & \multicolumn{2}{|c|}{$4 \mathrm{~Gy}$} \\
\hline & $\mu$ & SE & $\mu$ & SE & $\mu$ & SE & $\mu$ & SE \\
\hline$A D M$ & -1.44 & 0.08 & 1.14 & 0.13 & 1.22 & 0.24 & 1.24 & 0.24 \\
\hline$A G T$ & -1.88 & 0.16 & -1.48 & 0.21 & -1.36 & 0.08 & 1.11 & 0.13 \\
\hline$A K T 1$ & -1.01 & 0.05 & 1.11 & 0.06 & -1.11 & 0.14 & -1.16 & 0.13 \\
\hline$A L D H 3 A 2$ & -1.05 & 0.03 & -1.16 & 0.03 & 1.08 & 0.04 & -1.15 & 0.04 \\
\hline$B C L 2 A 1$ & -1.21 & 0.13 & 1.04 & 0.17 & 1.12 & 0.15 & -1.23 & 0.11 \\
\hline BCL2L1 & 1.17 & 0.13 & -1.16 & 0.10 & 1.36 & 0.10 & -1.68 & 0.04 \\
\hline BIRC2 & 1.08 & 0.07 & 1.06 & 0.07 & 1.26 & 0.12 & -1.17 & 0.08 \\
\hline BIRC3 & 1.34 & 0.20 & 1.66 & 0.24 & 1.29 & 0.30 & -1.16 & 0.20 \\
\hline C3 & 1.58 & 0.25 & 1.03 & 0.16 & -1.46 & 0.20 & -1.99 & 0.15 \\
\hline CCL11 & 1.97 & 0.81 & 1.10 & 0.45 & 1.46 & 0.45 & 1.68 & 0.52 \\
\hline CCL2 & 1.18 & 0.11 & 2.94 & 0.27 & 1.57 & 0.19 & 2.64 & 0.31 \\
\hline CCL22 & 1.24 & 0.23 & 1.57 & 0.29 & -1.26 & 0.04 & -1.12 & 0.04 \\
\hline CCL5 & -1.97 & 0.17 & -1.56 & 0.22 & -1.89 & 0.23 & 1.22 & 0.53 \\
\hline CCND1 & -1.77 & 0.11 & 1.03 & 0.19 & -1.23 & 0.11 & -1.24 & 0.11 \\
\hline CCR5 & -1.02 & 0.37 & -2.13 & 0.18 & 1.04 & 0.19 & 1.35 & 0.24 \\
\hline CD40 & 1.58 & 0.26 & -1.17 & 0.14 & 1.15 & 0.23 & -1.30 & 0.15 \\
\hline CD69 & -1.09 & 0.07 & 1.16 & 0.09 & -1.26 & 0.04 & -1.12 & 0.04 \\
\hline CD80 & -1.01 & 0.27 & -1.55 & 0.18 & 2.03 & 0.67 & -1.53 & 0.22 \\
\hline CD83 & 1.25 & 0.04 & 4.37 & 0.14 & 1.09 & 0.05 & 1.42 & 0.07 \\
\hline CDKN1A & -1.39 & 0.10 & 1.21 & 0.17 & -1.35 & 0.21 & -1.07 & 0.26 \\
\hline$C F B$ & 1.01 & 0.12 & 1.14 & 0.14 & 1.57 & 0.20 & -1.01 & 0.12 \\
\hline CSF1 & -1.15 & 0.08 & 1.69 & 0.15 & -1.06 & 0.02 & -1.01 & 0.02 \\
\hline CSF2 & -1.82 & 0.22 & -1.30 & 0.31 & -3.46 & 0.04 & 1.48 & 0.20 \\
\hline$C S F 2 R B$ & -1.30 & 0.06 & -1.03 & 0.07 & -1.26 & 0.04 & -1.12 & 0.04 \\
\hline CSF3 & -1.44 & 0.24 & -1.44 & 0.24 & 1.02 & 0.19 & 1.46 & 0.27 \\
\hline CXCL1 & 1.01 & 0.19 & 7.55 & 1.44 & -1.48 & 0.05 & 1.21 & 0.10 \\
\hline CXCL10 & -1.27 & 0.14 & 6.70 & 1.20 & -1.30 & 0.06 & -1.15 & 0.06 \\
\hline CXCL2 & 1.30 & 0.22 & 3.48 & 0.59 & 1.11 & 0.21 & 1.00 & 0.19 \\
\hline CXCL9 & 1.02 & 0.37 & -2.17 & 0.17 & 1.14 & 0.30 & -1.66 & 0.16 \\
\hline EGFR & -1.33 & 0.07 & -1.12 & 0.09 & -1.05 & 0.10 & -1.08 & 0.10 \\
\hline EGR2 & 1.17 & 0.39 & -1.66 & 0.20 & 1.57 & 0.41 & -1.52 & 0.17 \\
\hline$F 3$ & -1.15 & 0.10 & 1.47 & 0.17 & -1.01 & 0.13 & -1.00 & 0.13 \\
\hline$F 8$ & -1.22 & 0.12 & -1.06 & 0.13 & 1.19 & 0.01 & -1.01 & 0.01 \\
\hline FAS & -2.11 & 0.11 & -1.61 & 0.14 & 1.14 & 0.21 & 1.15 & 0.21 \\
\hline FASLG & -1.40 & 0.32 & -1.51 & 0.30 & -1.10 & 0.16 & 1.15 & 0.21 \\
\hline$G A D D 45 B$ & -1.06 & 0.30 & 2.19 & 0.69 & 1.69 & 0.59 & 2.06 & 0.72 \\
\hline ICAM1 & -1.57 & 0.10 & -1.64 & 0.10 & 1.14 & 0.14 & 1.37 & 0.17 \\
\hline IFNB1 & -1.24 & 0.05 & 1.02 & 0.06 & -1.26 & 0.04 & -1.12 & 0.04 \\
\hline
\end{tabular}


Table A6. Cont.

\begin{tabular}{|c|c|c|c|c|c|c|c|c|}
\hline \multirow[b]{3}{*}{ Symbol } & \multicolumn{4}{|c|}{ HEK wt } & \multicolumn{4}{|c|}{ RelA k.d. } \\
\hline & \multicolumn{2}{|c|}{$0.5 \mathrm{~Gy}$} & \multicolumn{2}{|c|}{$4 \mathrm{~Gy}$} & \multicolumn{2}{|c|}{$0.5 \mathrm{~Gy}$} & \multicolumn{2}{|c|}{$4 \mathrm{~Gy}$} \\
\hline & $\mu$ & SE & $\mu$ & SE & $\mu$ & SE & $\mu$ & SE \\
\hline IFNG & -1.84 & 0.16 & -1.46 & 0.20 & -1.26 & 0.04 & -1.12 & 0.04 \\
\hline IL12B & -1.35 & 0.16 & -1.49 & 0.14 & 1.25 & 0.06 & 1.30 & 0.06 \\
\hline IL15 & -1.32 & 0.15 & 1.07 & 0.22 & -1.21 & 0.04 & -1.41 & 0.03 \\
\hline IL1A & -1.39 & 0.12 & -1.83 & 0.09 & 1.57 & 0.33 & -1.40 & 0.15 \\
\hline IL1B & -1.35 & 0.07 & -1.07 & 0.09 & -1.02 & 0.10 & -1.18 & 0.08 \\
\hline IL1R2 & -1.29 & 0.22 & -1.99 & 0.14 & 1.01 & 0.18 & -1.80 & 0.10 \\
\hline$I L 1 R N$ & 1.24 & 0.23 & 1.57 & 0.29 & -1.26 & 0.04 & -1.12 & 0.04 \\
\hline IL2 & -1.62 & 0.13 & -1.28 & 0.16 & -1.26 & 0.04 & -1.12 & 0.04 \\
\hline IL2RA & 1.20 & 0.20 & 1.52 & 0.25 & -1.26 & 0.04 & -1.12 & 0.04 \\
\hline IL4 & -1.12 & 0.28 & -1.17 & 0.26 & -1.26 & 0.13 & 1.02 & 0.16 \\
\hline IL6 & -1.81 & 0.15 & -1.43 & 0.20 & -1.27 & 0.08 & 1.09 & 0.11 \\
\hline IL8 & 1.38 & 0.44 & 6.10 & 1.96 & -1.26 & 0.13 & 1.44 & 0.23 \\
\hline INS & -1.62 & 0.12 & -1.28 & 0.15 & -1.26 & 0.04 & -1.12 & 0.04 \\
\hline IRF1 & 1.06 & 0.12 & 2.85 & 0.33 & -1.09 & 0.08 & 1.40 & 0.11 \\
\hline LTA & 1.05 & 0.44 & -2.07 & 0.20 & 1.28 & 0.31 & -1.39 & 0.17 \\
\hline$L T B$ & 1.16 & 0.44 & -2.18 & 0.17 & 1.91 & 0.62 & -1.49 & 0.22 \\
\hline$M A P 2 K 6$ & -1.17 & 0.19 & -1.63 & 0.13 & 1.99 & 0.48 & 1.44 & 0.35 \\
\hline MMP9 & 1.24 & 0.07 & -1.04 & 0.06 & 1.09 & 0.20 & 1.07 & 0.20 \\
\hline$M Y C$ & -1.14 & 0.04 & 1.21 & 0.05 & 1.67 & 0.29 & 1.97 & 0.35 \\
\hline MYD88 & -1.05 & 0.24 & -1.25 & 0.21 & -1.35 & 0.25 & -1.10 & 0.30 \\
\hline NCOA3 & -1.18 & 0.06 & 1.06 & 0.08 & 1.18 & 0.08 & -1.17 & 0.06 \\
\hline NFKB1 & -1.24 & 0.12 & 2.09 & 0.30 & 1.04 & 0.03 & 1.05 & 0.03 \\
\hline NFKB2 & -1.25 & 0.09 & 2.52 & 0.29 & -1.02 & 0.16 & 1.04 & 0.17 \\
\hline NFKBIA & -1.11 & 0.08 & 3.55 & 0.31 & 1.05 & 0.12 & 1.47 & 0.17 \\
\hline NQO1 & -1.27 & 0.09 & -1.34 & 0.08 & 1.13 & 0.06 & -1.14 & 0.04 \\
\hline$N R 4 A 2$ & 1.09 & 0.19 & 1.11 & 0.19 & -1.20 & 0.14 & -1.40 & 0.12 \\
\hline$P D G F B$ & 1.02 & 0.11 & 1.28 & 0.14 & -1.26 & 0.04 & -1.12 & 0.04 \\
\hline PLAU & -1.64 & 0.10 & 1.08 & 0.18 & -1.09 & 0.20 & -1.47 & 0.15 \\
\hline PTGS2 & 1.39 & 0.04 & 2.12 & 0.06 & 1.07 & 0.19 & 1.01 & 0.18 \\
\hline$R E L$ & 1.11 & 0.15 & 1.84 & 0.25 & 1.02 & 0.05 & -1.17 & 0.04 \\
\hline RELA & 1.17 & 0.07 & 1.48 & 0.08 & 1.21 & 0.07 & 1.15 & 0.07 \\
\hline RELB & -1.39 & 0.26 & -1.09 & 0.33 & 1.01 & 0.19 & -1.20 & 0.16 \\
\hline SELE & -1.09 & 0.41 & -1.34 & 0.33 & -1.00 & 0.18 & 1.06 & 0.19 \\
\hline SELP & 1.01 & 0.11 & 1.28 & 0.13 & -1.26 & 0.04 & -1.12 & 0.04 \\
\hline SNAP25 & -1.74 & 0.14 & -2.36 & 0.10 & -1.32 & 0.24 & -1.69 & 0.18 \\
\hline SOD2 & -1.17 & 0.06 & -1.06 & 0.06 & 1.24 & 0.12 & 1.29 & 0.13 \\
\hline STAT1 & 1.19 & 0.14 & 1.40 & 0.17 & -1.01 & 0.04 & -1.03 & 0.04 \\
\hline STAT3 & -1.29 & 0.09 & -1.32 & 0.09 & 1.11 & 0.07 & -1.08 & 0.06 \\
\hline STAT5B & -1.16 & 0.13 & -1.18 & 0.13 & -1.14 & 0.12 & -1.40 & 0.10 \\
\hline TNF & 1.08 & 0.12 & 6.72 & 0.76 & -1.26 & 0.04 & -1.12 & 0.04 \\
\hline TNFRSF1B & 1.07 & 0.30 & -2.04 & 0.14 & 2.88 & 1.60 & -2.65 & 0.21 \\
\hline TNFSF10 & 1.06 & 0.27 & -1.65 & 0.15 & 1.58 & 0.60 & -2.19 & 0.17 \\
\hline TP53 & -1.03 & 0.02 & 1.49 & 0.03 & -1.12 & 0.02 & -1.03 & 0.02 \\
\hline TRAF2 & -1.13 & 0.09 & 1.32 & 0.14 & -1.00 & 0.04 & 1.15 & 0.05 \\
\hline VCAM1 & -1.77 & 0.15 & -1.10 & 0.24 & -1.26 & 0.04 & -1.12 & 0.04 \\
\hline XIAP & -1.01 & 0.12 & 1.19 & 0.14 & -1.02 & 0.12 & -1.32 & 0.09 \\
\hline АСТВ & 1.25 & 0.11 & 1.12 & 0.10 & 1.19 & 0.17 & 1.24 & 0.18 \\
\hline$B 2 M$ & -1.08 & 0.07 & -1.01 & 0.08 & -1.06 & 0.04 & -1.07 & 0.04 \\
\hline GAPDH & -1.02 & 0.05 & -1.12 & 0.04 & 1.13 & 0.05 & 1.10 & 0.05 \\
\hline HPRT1 & -1.10 & 0.04 & -1.05 & 0.04 & -1.21 & 0.11 & -1.21 & 0.11 \\
\hline RPLPO & 1.01 & 0.05 & 1.10 & 0.05 & 1.01 & 0.05 & 1.01 & 0.05 \\
\hline
\end{tabular}




\section{References}

1. Berger, T.; Bilski, P.; Hajek, M.; Puchalska, M.; Reitz, G. The MATROSHKA Experiment: Results and Comparison from Extravehicular Activity (MTR-1) and Intravehicular Activity (MTR-2A/2B) Exposure. Radiat. Res. 2013, 180, 622-637. [CrossRef] [PubMed]

2. Puchalska, M.; Bilski, P.; Berger, T.; Hajek, M.; Horwacik, T.; Korner, C.; Olko, P.; Shurshakov, V.; Reitz, G. NUNDO: A Numerical Model of a Human Torso Phantom and Its Application to Effective Dose Equivalent Calculations for Astronauts at the ISS. Radiat. Environ. Biophys. 2014, 53, 719-727. [CrossRef] [PubMed]

3. Zeitlin, C.; Hassler, D.M.; Cucinotta, F.A.; Ehresmann, B.; Wimmer-Schweingruber, R.F.; Brinza, D.E.; Kang, S.; Weigle, G.; Bottcher, S.; Bohm, E.; et al. Measurements of Energetic Particle Radiation in Transit to Mars on the Mars Science Laboratory. Science 2013, 340, 1080-1084. [CrossRef] [PubMed]

4. Hassler, D.M.; Zeitlin, C.; Wimmer-Schweingruber, R.F.; Ehresmann, B.; Rafkin, S.; Eigenbrode, J.L.; Brinza, D.E.; Weigle, G.; Bottcher, S.; Bohm, E.; et al. Mars' Surface Radiation Environment Measured with the Mars Science Laboratory's Curiosity Rover. Science 2014, 343, 1244797. [CrossRef] [PubMed]

5. National Council on Radiation Protection and Measurements. Information Needed to Make Radiation Protection Recommendations for Space Missions beyond Low-Earth Orbit: Recommendations of the National Council on Radiation Protection and Measurements; National Council on Radiation Protection and Measurements: Bethesda, MD, USA, 2006.

6. Cucinotta, F.A.; Manuel, F.K.; Jones, J.; Iszard, G.; Murrey, J.; Djojonegro, B.; Wear, M. Space Radiation and Cataracts in Astronauts. Radiat. Res. 2001, 156, 460-466. [CrossRef]

7. Chylack, L.T., Jr.; Peterson, L.E.; Feiveson, A.H.; Wear, M.L.; Manuel, F.K.; Tung, W.H.; Hardy, D.S.; Marak, L.J.; Cucinotta, F.A. NASA Study of Cataract in Astronauts (NASCA). Report 1: Cross-Sectional Study of the Relationship of Exposure to Space Radiation and Risk of Lens Opacity. Radiat. Res. 2009, 172, 10-20. [CrossRef] [PubMed]

8. Hughson, R.L.; Helm, A.; Durante, M. Heart in Space: Effect of the Extraterrestrial Environment on the Cardiovascular System. Nat. Rev. Cardiol. 2018, 15, 167-180. [CrossRef] [PubMed]

9. Jandial, R.; Hoshide, R.; Waters, J.D.; Limoli, C.L. Space-Brain: The Negative Effects of Space Exposure on the Central Nervous System. Surg. Neurol. Intern. 2018, 9, 9.

10. Sanzari, J.K.; Wan, X.S.; Muehlmatt, A.; Lin, L.; Kennedy, A.R. Comparison of Changes over Time in Leukocyte Counts in Yucatan Minipigs Irradiated with Simulated Solar Particle Event-Like Radiation. Life Sci. Space Res. 2015, 4, 11-16. [CrossRef] [PubMed]

11. Sanzari, J.K.; Diffenderfer, E.S.; Hagan, S.; Billings, P.C.; Gridley, D.S.; Seykora, J.T.; Kennedy, A.R.; Cengel, K.A. Dermatopathology Effects of Simulated Solar Particle Event Radiation Exposure in the Porcine Model. Life Sci. Space Res. 2015, 6, 21-28. [CrossRef] [PubMed]

12. Pecaut, M.J.; Gridley, D.S. The Impact of Mouse Strain on Iron Ion Radio-Immune Response of Leukocyte Populations. Int. J. Radiat. Biol. 2010, 86, 409-419. [CrossRef] [PubMed]

13. Georgakilas, A.G.; O'Neill, P.; Stewart, R.D. Induction and Repair of Clustered DNA Lesions: What do We Know So Far? Radiat. Res. 2013, 180, 100-109. [CrossRef] [PubMed]

14. Hellweg, C.E.; Spitta, L.F.; Henschenmacher, B.; Diegeler, S.; Baumstark-Khan, C. Transcription Factors in the Cellular Response to Charged Particle Exposure. Front. Oncol. 2016, 6, 61. [CrossRef] [PubMed]

15. Colombo, F.; Zambrano, S.; Agresti, A. NF-kappaB, the Importance of Being Dynamic: Role and Insights in Cancer. Biomedicines 2018, 6, 45. [CrossRef] [PubMed]

16. Brach, M.A.; Hass, R.; Sherman, M.L.; Gunji, H.; Weichselbaum, R.; Kufe, D. Ionizing Radiation Induces Expression and Binding Activity of the Nuclear Factor Kappa B. J. Clin. Investig. 1991, 88, 691-695. [CrossRef] [PubMed]

17. Sen, R.; Baltimore, D. Inducibility of Kappa Immunoglobulin Enhancer-Binding Protein Nf-Kappa B by a Posttranslational Mechanism. Cell 1986, 47, 921-928. [CrossRef]

18. Baumstark-Khan, C.; Hellweg, C.E.; Arenz, A.; Meier, M.M. Cellular Monitoring of the Nuclear Factor kappaB Pathway for Assessment of Space Environmental Radiation. Radiat. Res. 2005, 164, 527-530. [CrossRef] [PubMed]

19. Hellweg, C.E.; Baumstark-Khan, C.; Schmitz, C.; Lau, P.; Meier, M.M.; Testard, I.; Berger, T.; Reitz, G. Carbon-Ion-Induced Activation of the NF-kappaB Pathway. Radiat. Res. 2011, 175, 424-431. [CrossRef] [PubMed] 
20. Hellweg, C.E.; Baumstark-Khan, C.; Schmitz, C.; Lau, P.; Meier, M.M.; Testard, I.; Berger, T.; Reitz, G. Activation of the Nuclear Factor kappaB Pathway by Heavy Ion Beams of Different Linear Energy Transfer. Int. J. Radiat. Biol. 2011, 87, 954-963. [CrossRef] [PubMed]

21. Reitz, G.; Berger, T.; Bilski, P.; Facius, R.; Hajek, M.; Petrov, V.; Puchalska, M.; Zhou, D.; Bossler, J.; Akatov, Y.; et al. Astronaut's Organ Doses Inferred from Measurements in a Human Phantom Outside the International Space Station. Radiat. Res. 2009, 171, 225-235. [CrossRef] [PubMed]

22. Habraken, Y.; Piette, J. NF-kappaB Activation by Double-Strand Breaks. Biochem. Pharmacol. 2006, 72, 1132-1141. [CrossRef] [PubMed]

23. Hellweg, C.E. The Nuclear Factor kappaB Pathway: A link to the Immune System in the Radiation Response. Cancer Lett. 2015, 368, 275-289. [CrossRef] [PubMed]

24. Ghosh, S.; May, M.J.; Kopp, E.B. NF-kappa B and Rel Proteins: Evolutionarily Conserved Mediators of Immune Responses. Annu. Rev. Immunol. 1998, 16, 225-260. [CrossRef] [PubMed]

25. Baichwal, V.R.; Baeuerle, P.A. Activate NF-kappa B or Die? Curr. Biol. 1997, 7, R94-96. [CrossRef]

26. Chishti, A.A.; Baumstark-Khan, C.; Koch, K.; Kolanus, W.; Feles, S.; Konda, B.; Azhar, A.; Spitta, L.F.; Henschenmacher, B.; Diegeler, S.; et al. Linear Energy Transfer Modulates Radiation-Induced NF-kappa B Activation and Expression of its Downstream Target Genes. Radiat. Res. 2018, 189, 354-370. [CrossRef] [PubMed]

27. Hellweg, C.E.; Baumstark-Khan, C.; Horneck, G. Generation of Stably Transfected Mammalian Cell Lines as Fluorescent Screening Assay for NF-kappaB Activation-Dependent Gene Expression. J. Biomol. Screen. 2003, 8, 511-521. [CrossRef] [PubMed]

28. Li, X.; Zhao, X.; Fang, Y.; Jiang, X.; Duong, T.; Fan, C.; Huang, C.C.; Kain, S.R. Generation of Destabilized Green Fluorescent Protein as a Transcription Reporter. J. Biol. Chem. 1998, 273, 34970-34975. [CrossRef] [PubMed]

29. Natarajan, M.; Aravindan, N.; Meltz, M.L.; Herman, T.S. Post-Translational Modification of I-kappa B Alpha Activates NF-kappa B in Human Monocytes Exposed to 56Fe Ions. Radiat. Environ. Biophys. 2002, 41, 139-144. [CrossRef] [PubMed]

30. Tungjai, M.; Whorton, E.B.; Rithidech, K.N. Persistence of Apoptosis and Inflammatory Responses in the Heart and Bone Marrow of Mice Following Whole-Body Exposure to (2)(8)Silicon ((2)(8)Si) ions. Radiat. Environ. Biophys. 2013, 52, 339-350. [CrossRef] [PubMed]

31. Hickson, I.; Zhao, Y.; Richardson, C.J.; Green, S.J.; Martin, N.M.; Orr, A.I.; Reaper, P.M.; Jackson, S.P.; Curtin, N.J.; Smith, G.C. Identification and Characterization of a Novel and Specific Inhibitor of the Ataxia-Telangiectasia Mutated Kinase ATM. Cancer Res. 2004, 64, 9152-9159. [CrossRef] [PubMed]

32. Xue, L.; Yu, D.; Furusawa, Y.; Okayasu, R.; Tong, J.; Cao, J.; Fan, S. Regulation of ATM in DNA Double Strand Break Repair Accounts for the Radiosensitivity in Human Cells Exposed to High Linear Energy Transfer Ionizing Radiation. Mutat. Res. 2009, 670, 15-23. [CrossRef] [PubMed]

33. Takahashi, A.; Yamakawa, N.; Kirita, T.; Omori, K.; Ishioka, N.; Furusawa, Y.; Mori, E.; Ohnishi, K.; Ohnishi, T. DNA Damage Recognition Proteins Localize along Heavy Ion Induced Tracks in the Cell Nucleus. J. Radiat. Res. 2008, 49, 645-652. [CrossRef] [PubMed]

34. Ghosh, S.; Narang, H.; Sarma, A.; Krishna, M. DNA Damage Response Signaling in Lung Adenocarcinoma A549 Cells Following Gamma and Carbon Beam Irradiation. Mutat. Res. 2011, 716, 10-19. [CrossRef] [PubMed]

35. Li, Q.; Gao, Y.; Xu, Z.G.; Jiang, H.; Yu, Y.Y.; Zhu, Z.G. Effect of Antisense Oligodeoxynucleotide Targeted Against NF-kappaB/P65 on Cell Proliferation and Tumorigenesis of Gastric Cancer. Clin. Exp. Med. 2013, 13, 11-19. [CrossRef] [PubMed]

36. Wang, F.; He, W.; Fanghui, P.; Wang, L.; Fan, Q. NF-kappaBP65 Promotes Invasion and Metastasis of Oesophageal Squamous Cell Cancer by Regulating Matrix Metalloproteinase-9 and Epithelial-to-Mesenchymal Transition. Cell Biol. Int. 2013, 37, 780-788. [CrossRef] [PubMed]

37. Bonavia, R.; Inda, M.M.; Vandenberg, S.; Cheng, S.Y.; Nagane, M.; Hadwiger, P.; Tan, P.; Sah, D.W.; Cavenee, W.K.; Furnari, F.B. EGFRvIII Promotes Glioma Angiogenesis and Growth through the NF-kappaB, Interleukin-8 Pathway. Oncogene 2012, 31, 4054-4066. [CrossRef] [PubMed]

38. Shi, Y.; Wang, S.Y.; Yao, M.; Sai, W.L.; Wu, W.; Yang, J.L.; Cai, Y.; Zheng, W.J.; Yao, D.F. Chemosensitization of HepG2 Cells by Suppression of NF-kappaB/p65 Gene Transcription with Specific-siRNA. World J. Gastroenterol. 2015, 21, 12814-12821. [CrossRef] [PubMed] 
39. Xiao, J.; Duan, X.; Yin, Q.; Miao, Z.; Yu, H.; Chen, C.; Zhang, Z.; Wang, J.; Li, Y. The Inhibition of Metastasis and Growth of Breast Cancer by Blocking the NF-kappaB Signaling Pathway Using Bioreducible PEI-based/p65 shRNA Complex Nanoparticles. Biomaterials 2013, 34, 5381-5390. [CrossRef] [PubMed]

40. Toualbi-Abed, K.; Daniel, F.; Guller, M.C.; Legrand, A.; Mauriz, J.L.; Mauviel, A.; Bernuau, D. Jun D Cooperates with p65 to Activate the Proximal kappaB Site of the Cyclin D1 Promoter: Role of PI3K/PDK-1. Carcinogenesis 2008, 29, 536-543. [CrossRef] [PubMed]

41. Widera, D.; Mikenberg, I.; Elvers, M.; Kaltschmidt, C.; Kaltschmidt, B. Tumor Necrosis Factor Alpha Triggers Proliferation of Adult Neural Stem Cells via IKK/NF-kappaB Signaling. BMC Neurosci. 2006, 7, 64. [CrossRef] [PubMed]

42. Guttridge, D.C.; Albanese, C.; Reuther, J.Y.; Pestell, R.G.; Baldwin, A.S., Jr. NF-kappaB Controls Cell Growth and Differentiation through Transcriptional Regulation of Cyclin D1. Mol. Cell. Biol. 1999, 19, 5785-5799. [CrossRef] [PubMed]

43. Galardi, S.; Mercatelli, N.; Farace, M.G.; Ciafre, S.A. NF-kB and c-Jun Induce the Expression of the Oncogenic miR-221 and miR-222 in Prostate Carcinoma and Glioblastoma Cells. Nucleic Acids Res. 2011, 39, 3892-3902. [CrossRef] [PubMed]

44. Williams, J.R.; Zhang, Y.; Zhou, H.; Osman, M.; Cha, D.; Kavet, R.; Cuccinotta, F.; Dicello, J.F.; Dillehay, L.E. Predicting Cancer Rates in Astronauts from Animal Carcinogenesis Studies and Cellular Markers. Mutat. Res. 1999, 430, 255-269. [CrossRef]

45. Watson, C.; Miller, D.A.; Chin-Sinex, H.; Losch, A.; Hughes, W.; Sweeney, C.; Mendonca, M.S. Suppression of NF-kappaB Activity by Parthenolide Induces X-ray Sensitivity through Inhibition of Split-Dose Repair in TP53 Null Prostate Cancer Cells. Radiat. Res. 2009, 171, 389-396. [CrossRef] [PubMed]

46. Veuger, S.J.; Hunter, J.E.; Durkacz, B.W. Ionizing Radiation-Induced NF-kappaB Activation Requires PARP-1 Function to Confer Radioresistance. Oncogene 2009, 28, 832-842. [CrossRef] [PubMed]

47. Wang, C.Y.; Mayo, M.W.; Baldwin, A.S., Jr. TNF- and Cancer Therapy-Induced Apoptosis: Potentiation by Inhibition of NF-kappaB. Science 1996, 274, 784-787. [CrossRef] [PubMed]

48. Jung, M.; Dritschilo, A. NF-kappa B Signaling Pathway as a Target for Human Tumor Radiosensitization. Semin. Radiat. Oncol. 2001, 11, 346-351. [CrossRef] [PubMed]

49. Russo, S.M.; Tepper, J.E.; Baldwin, A.S., Jr.; Liu, R.; Adams, J.; Elliott, P.; Cusack, J.C., Jr. Enhancement of Radiosensitivity by Proteasome Inhibition: Implications for a Role of NF-kappaB. Int. J. Radiat. Oncol. Biol. Phys. 2001, 50, 183-193. [CrossRef]

50. Criswell, T.; Leskov, K.; Miyamoto, S.; Luo, G.; Boothman, D.A. Transcription Factors Activated in Mammalian Cells after Clinically Relevant Doses of Ionizing Radiation. Oncogene 2003, 22, 5813-5827. [CrossRef] [PubMed]

51. Thyss, R.; Virolle, V.; Imbert, V.; Peyron, J.F.; Aberdam, D.; Virolle, T. NF-kappaB/Egr-1/Gadd45 are Sequentially Activated upon UVB Irradiation to Mediate Epidermal Cell Death. EMBO J. 2005, 24, 128-137. [CrossRef] [PubMed]

52. Kraft, D.; Rall, M.; Volcic, M.; Metzler, E.; Groo, A.; Stahl, A.; Bauer, L.; Nasonova, E.; Salles, D.; Taucher-Scholz, G.; et al. NF-kappaB-dependent DNA Damage-Signaling Differentially Regulates DNA Double-Strand Break Repair Mechanisms in Immature and Mature Human Hematopoietic Cells. Leukemia 2015, 29, 1543-1554. [CrossRef] [PubMed]

53. Mori, E.; Takahashi, A.; Yamakawa, N.; Kirita, T.; Ohnishi, T. High LET Heavy Ion Radiation Induces p53-independent Apoptosis. J. Radiat. Res. 2009, 50, 37-42. [CrossRef] [PubMed]

54. Takahashi, A.; Matsumoto, H.; Yuki, K.; Yasumoto, J.; Kajiwara, A.; Aoki, M.; Furusawa, Y.; Ohnishi, K.; Ohnishi, T. High-LET Radiation Enhanced Apoptosis but Not Necrosis Regardless of p53 Status. Int. J. Radiat. Oncol. Biol. Phys. 2004, 60, 591-597. [CrossRef] [PubMed]

55. Lu, W.; Zhang, G.; Zhang, R.; Flores, L.G., 2nd; Huang, Q.; Gelovani, J.G.; Li, C. Tumor Site-Specific Silencing of NF-kappaB p65 by Targeted Hollow Gold Nanosphere-Mediated Photothermal Transfection. Cancer Res. 2010, 70, 3177-3188. [CrossRef] [PubMed]

56. Vlahopoulos, S.; Boldogh, I.; Casola, A.; Brasier, A.R. Nuclear Factor-kappaB-dependent Induction of Interleukin-8 Gene Expression by Tumor Necrosis Factor Alpha: Evidence for an Antioxidant Sensitive Activating Pathway Distinct from Nuclear Translocation. Blood 1999, 94, 1878-1889. [PubMed] 
57. Janus, P.; Szoltysek, K.; Zajac, G.; Stokowy, T.; Walaszczyk, A.; Widlak, W.; Wojtas, B.; Gielniewski, B.; Iwanaszko, M.; Braun, R.; et al. Pro-Inflammatory Cytokine and High Doses of Ionizing Radiation have Similar Effects on the Expression of NF-kappaB-dependent Genes. Cell. Signal. 2018, 46, 23-31. [CrossRef] [PubMed]

58. Roach, D.R.; Bean, A.G.; Demangel, C.; France, M.P.; Briscoe, H.; Britton, W.J. TNF Regulates Chemokine Induction Essential for Cell Recruitment, Granuloma Formation, and Clearance of Mycobacterial Infection. J. Immunol. 2002, 168, 4620-4627. [CrossRef] [PubMed]

59. Imadome, K.; Iwakawa, M.; Nojiri, K.; Tamaki, T.; Sakai, M.; Nakawatari, M.; Moritake, T.; Yanagisawa, M.; Nakamura, E.; Tsujii, H.; et al. Upregulation of Stress-Response Genes with Cell Cycle Arrest Induced by Carbon Ion Irradiation in Multiple Murine Tumors Models. Cancer Biol. Ther. 2008, 7, 208-217. [CrossRef] [PubMed]

60. Coward, W.R.; Okayama, Y.; Sagara, H.; Wilson, S.J.; Holgate, S.T.; Church, M.K. NF-kappa B and TNF-alpha: A Positive Autocrine Loop in Human Lung Mast Cells? J. Immunol. 2002, 169, 5287-5293. [CrossRef] [PubMed]

61. May, M.J.; Ghosh, S. Signal Transduction through NF-kappa B. Immunol. Today 1998, 19, 80-88. [CrossRef]

62. Baldwin, A.S., Jr. The NF-kappa B and I kappa B Proteins: New Discoveries and Insights. Annu. Rev. Immunol. 1996, 14, 649-683. [CrossRef] [PubMed]

63. Matsumoto, Y.; Iwakawa, M.; Furusawa, Y.; Ishikawa, K.; Aoki, M.; Imadome, K.; Matsumoto, I.; Tsujii, H.; Ando, K.; Imai, T. Gene Expression Analysis in Human Malignant Melanoma Cell Lines Exposed to Carbon Beams. Int. J. Radiat. Biol. 2008, 84, 299-314. [CrossRef] [PubMed]

64. Souto-Carneiro, M.M.; Fritsch, R.; Sepulveda, N.; Lagareiro, M.J.; Morgado, N.; Longo, N.S.; Lipsky, P.E. The NF-kappaB Canonical Pathway is Involved in the Control of the Exonucleolytic Processing of Coding Ends during V(D)J Recombination. J. Immunol. 2008, 180, 1040-1049. [CrossRef] [PubMed]

65. Nelson, G.A.; Jones, T.A.; Chesnut, A.; Smith, A.L. Radiation-Induced Gene Expression in the Nematode Caenorhabditis Elegans. J. Radiat. Res. 2002, 43, S199-S203. [CrossRef] [PubMed]

66. Alwood, J.S.; Shahnazari, M.; Chicana, B.; Schreurs, A.S.; Kumar, A.; Bartolini, A.; Shirazi-Fard, Y.; Globus, R.K. Ionizing Radiation Stimulates Expression of Pro-Osteoclastogenic Genes in Marrow and Skeletal Tissue. J. Interferon Cytokine Res. 2015, 35, 480-487. [CrossRef] [PubMed]

67. Josson, S.; Xu, Y.; Fang, F.; Dhar, S.K.; St Clair, D.K.; St Clair, W.H. RelB Regulates Manganese Superoxide Dismutase Gene and Resistance to Ionizing Radiation of Prostate Cancer Cells. Oncogene 2006, 25, 1554-1559. [CrossRef] [PubMed]

68. Xu, Y.; Fang, F.; St Clair, D.K.; Josson, S.; Sompol, P.; Spasojevic, I.; St Clair, W.H. Suppression of RelB-Mediated Manganese Superoxide Dismutase Expression Reveals a Primary Mechanism for Radiosensitization Effect of 1alpha,25-dihydroxyvitamin D(3) in Prostate Cancer Cells. Mol. Cancer Ther. 2007, 6, 2048-2056. [CrossRef] [PubMed]

69. Xu, Y.; Fang, F.; St Clair, D.K.; Sompol, P.; Josson, S.; St Clair, W.H. SN52, A Novel Nuclear Factor-kappaB Inhibitor, Blocks Nuclear Import of RelB:p52 Dimer and Sensitizes Prostate Cancer Cells to Ionizing Radiation. Mol. Cancer Ther. 2008, 7, 2367-2376. [CrossRef] [PubMed]

70. Holley, A.K.; Xu, Y.; St Clair, D.K.; St Clair, W.H. RelB Regulates Manganese Superoxide Dismutase Gene and Resistance to Ionizing Radiation of Prostate Cancer Cells. Ann. N. Y. Acad. Sci. 2010, 1201, 129-136. [CrossRef] [PubMed]

71. Ray, M.; Yunis, R.; Chen, X.; Rocke, D.M. Comparison of Low and High Dose Ionising Radiation Using Topological Analysis of Gene Coexpression Networks. BMC Genom. 2012, 13, 190. [CrossRef] [PubMed]

72. Fujimoto, Y.; Tedder, T.F. CD83: A Regulatory Molecule of the Immune System with Great Potential for Therapeutic Application. J. Med. Dent. Sci. 2006, 53, 85-91. [PubMed]

73. McKinsey, T.A.; Chu, Z.; Tedder, T.F.; Ballard, D.W. Transcription Factor NF-kappaB Regulates Inducible CD83 Gene Expression in Activated T Lymphocytes. Mol. Immunol. 2000, 37, 783-788. [CrossRef]

74. Yang, Y.; Wang, X.; Moore, D.R.; Lightfoot, S.A.; Huycke, M.M. TNF-alpha Mediates Macrophage-Induced Bystander Effects through Netrin-1. Cancer Res. 2012, 72, 5219-5229. [CrossRef] [PubMed] 
75. Onizawa, M.; Nagaishi, T.; Kanai, T.; Nagano, K.; Oshima, S.; Nemoto, Y.; Yoshioka, A.; Totsuka, T.; Okamoto, R.; Nakamura, T.; et al. Signaling Pathway via TNF-alpha/NF-kappaB in Intestinal Epithelial Cells may be Directly Involved in Colitis-Associated Carcinogenesis. Am. J. Physiol. Gastrointest. Liver Physiol. 2009, 296, G850-G859. [CrossRef] [PubMed]

76. Chan, A.T.; Ogino, S.; Giovannucci, E.L.; Fuchs, C.S. Inflammatory Markers are Associated with Risk of Colorectal Cancer and Chemopreventive Response to Anti-Inflammatory Drugs. Gastroenterology 2011, 140, 799-808. [CrossRef] [PubMed]

77. Thommesen, L.; Laegreid, A. Distinct Differences between TNF Receptor 1- and TNF Receptor 2-mediated Activation of NFkappaB. J. Biochem. Mol. Biol. 2005, 38, 281-289. [PubMed]

78. Chen, G.; Goeddel, D.V. TNF-R1 Signaling: A Beautiful Pathway. Science 2002, 296, 1634-1635. [CrossRef] [PubMed]

79. Meng, Z.; Lou, S.; Tan, J.; Xu, K.; Jia, Q.; Zheng, W. Nuclear Factor-kappa B Inhibition can Enhance Apoptosis of Differentiated Thyroid Cancer Cells Induced by 131I. PLoS ONE 2012, 7, e33597. [CrossRef] [PubMed]

80. Baggiolini, M.; Walz, A.; Kunkel, S.L. Neutrophil-Activating Peptide-1/interleukin 8, a Novel Cytokine that Activates Neutrophils. J. Clin. Inv. 1989, 84, 1045-1049. [CrossRef] [PubMed]

81. Stein, B.; Baldwin, A.S., Jr. Distinct Mechanisms for Regulation of the Interleukin-8 Gene Involve Synergism and Cooperativity between C/EBP and NF-kappa B. Mol. Cell. Biol. 1993, 13, 7191-7198. [CrossRef] [PubMed]

82. Wu, G.D.; Lai, E.J.; Huang, N.; Wen, X. Oct-1 and CCAAT/enhancer-binding Protein (C/EBP) Bind to Overlapping Elements within the Interleukin-8 Promoter. The role of Oct-1 as a Transcriptional Repressor. J. Biol. Chem. 1997, 272, 2396-2403. [CrossRef] [PubMed]

83. Stewart, J.; Ko, Y.H.; Kennedy, A.R. Protective Effects of L-Selenomethionine on Space Radiation Induced Changes in Gene Expression. Radiat. Environ. Biophys. 2007, 46, 161-165. [CrossRef] [PubMed]

84. Walenta, S.; Mueller-Klieser, W. Differential Superiority of Heavy Charged-Particle Irradiation to X-rays: Studies on Biological Effectiveness and Side Effect Mechanisms in Multicellular Tumor and Normal Tissue Models. Front. Oncol. 2016, 6, 30. [CrossRef] [PubMed]

85. Tschachojan, V.; Schroer, H.; Averbeck, N.; Mueller-Klieser, W. Carbon Ions and X-rays Induce Proinflammatory Effects in 3D Oral Mucosa Models with and without PBMCs. Oncol. Rep. 2014, 32, 1820-1828. [CrossRef] [PubMed]

86. Parihar, V.K.; Maroso, M.; Syage, A.; Allen, B.D.; Angulo, M.C.; Soltesz, I.; Limoli, C.L. Persistent Nature of Alterations in Cognition and Neuronal Circuit Excitability after Exposure to Simulated Cosmic Radiation in Mice. Exp. Neurol. 2018, 305, 44-55. [CrossRef] [PubMed]

87. Parihar, V.K.; Allen, B.D.; Caressi, C.; Kwok, S.; Chu, E.; Tran, K.K.; Chmielewski, N.N.; Giedzinski, E.; Acharya, M.M.; Britten, R.A.; et al. Cosmic Radiation Exposure and Persistent Cognitive Dysfunction. Sci. Rep. 2016, 6, 34774. [CrossRef] [PubMed]

88. Choudhury, A.; Cuddihy, A.; Bristow, R.G. Radiation and New Molecular Agents Part I: Targeting ATM-ATR Checkpoints, DNA Repair, and the Proteasome. Semin. Radiat. Oncol. 2006, 16, 51-58. [CrossRef] [PubMed]

89. Ao, N.; Chen, Q.; Liu, G. The Small Molecules Targeting Ubiquitin-Proteasome System for Cancer Therapy. Comb. Chem. High Throughput Screen. 2017, 20, 403-413. [CrossRef] [PubMed]

90. Salminen, A.; Lehtonen, M.; Suuronen, T.; Kaarniranta, K.; Huuskonen, J. Terpenoids: Natural Inhibitors of NF-kappaB Signaling with Anti-Inflammatory and Anticancer Potential. Cell. Mol. Life Sci. 2008, 65, 2979-2999. [CrossRef] [PubMed]

91. Jain, H.; Dhingra, N.; Narsinghani, T.; Sharma, R. Insights into the Mechanism of Natural Terpenoids as NF-kappaB Inhibitors: An Overview on Their Anticancer Potential. Exp. Oncol. 2016, 38, 158-168. [PubMed]

92. Hellweg, C.E.; Langen, B.; Klimow, G.; Ruscher, R.; Schmitz, C.; Baumstark-Khan, C.; Reitz, G. Up-Stream Events in the Nuclear Factor kB Activation Cascade in Response to Sparsely Ionizing Radiation. Adv. Space Res. 2009, 44, 907-916. [CrossRef]

93. Burdelya, L.G.; Krivokrysenko, V.I.; Tallant, T.C.; Strom, E.; Gleiberman, A.S.; Gupta, D.; Kurnasov, O.V.; Fort, F.L.; Osterman, A.L.; Didonato, J.A.; et al. An Agonist of Toll-Like Receptor 5 Has Radioprotective Activity in Mouse and Primate Models. Science 2008, 320, 226-230. [CrossRef] [PubMed]

94. Graham, F.L.; Smiley, J.; Russell, W.C.; Nairn, R. Characteristics of a Human Cell Line Transformed by DNA from Human Adenovirus Type 5. J. Gen. Virol. 1977, 36, 59-74. [CrossRef] [PubMed] 
95. Durantel, F.; Balanzat, E.; Cassimi, A.; Chevalier, F.; Ngono-Ravache, Y.; Madi, T.; Poully, J.-C.; Ramillon, J.M.; Rothard, H.; Ropars, F.; et al. Dosimetry for Radiobiology Experiments at GANIL. Nucl. Instrum. Methods Phys. Res. Sect. A: Accel. Spectrom. Detect. Assoc. Equip. 2016, 816, 70-77. [CrossRef]

96. Wulf, H.; Kraft-Weyrather, W.; Miltenburger, H.G.; Blakely, E.A.; Tobias, C.A.; Kraft, G. Heavy-Ion Effects on Mammalian Cells: Inactivation Measurements with Different Cell Lines. Radiat. Res. Suppl. 1985, 8, S122-S134. [CrossRef] [PubMed] 